Bijan Nekoueishahraki

Synthesis, Structure and Reactivity of

Bismuth(III) and Aluminum(III) Complexes

Supported by Nitrogen Donor Ligands

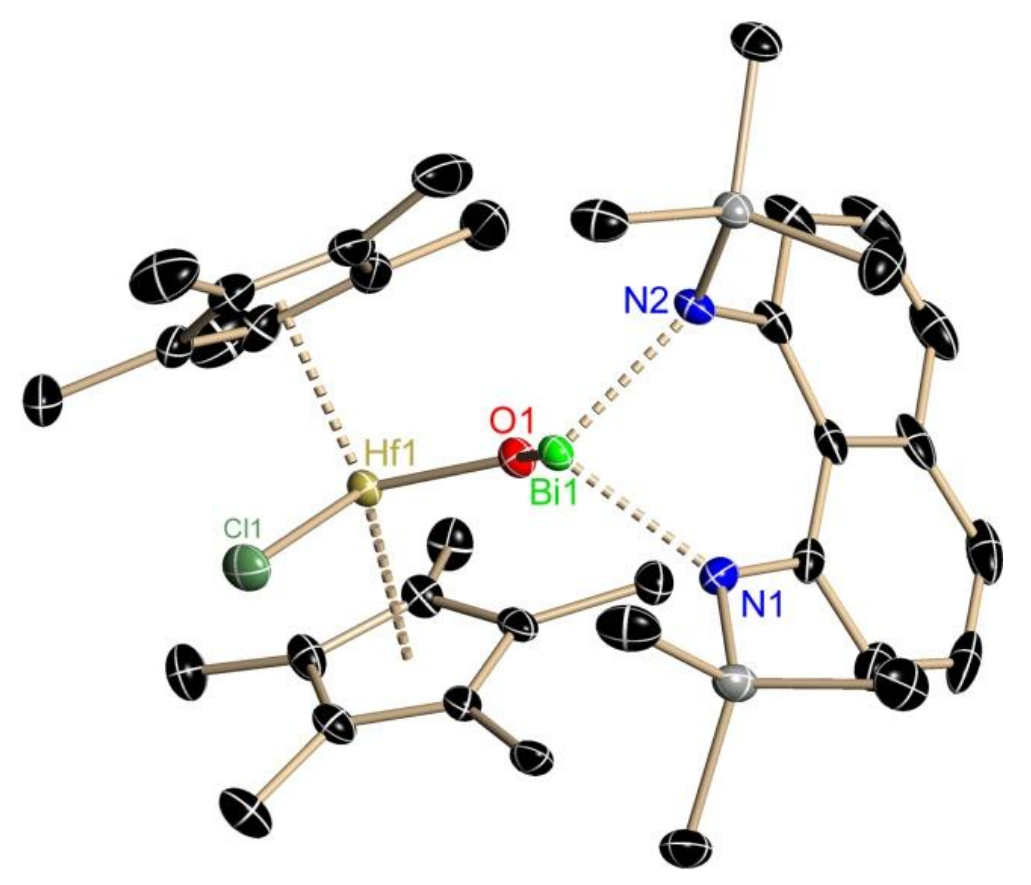

Göttingen 2009 


\title{
Synthesis, Structure and Reactivity of \\ Bismuth(III) and Aluminum(III) Complexes Supported by Nitrogen Donor Ligands
}

\author{
Dissertation \\ zur Erlangung des Doktorgrades \\ der Mathematisch-Naturwissenschaftlichen Fakultäten \\ der Georg-August-Universität zu Göttingen
}

vorgelegt von

Bijan Nekoueishahraki

aus Shahrekord

(IRAN)

Göttingen 2009 
D 7

Referent: $\quad$ Prof. Dr. Dr. h.c. mult. Herbert W. Roesky

Koreferent: $\quad$ Prof. Dr. Dietmar Stalke

Tag der mündlichem Prüfung: 
Dedicated ta my mather and in the memary of my father for their lave and affection 


\section{Acknowledgment}

The work described in this doctoral dissertation has been carried out under the guidance and supervision of Professor Dr. Dr. h. c. mult H. W. Roesky at the Institut für Anorganische Chemie der Georg-August-Universität in Göttingen between January 2006 and January 2010. I would like to express my deepest gratitude to my supervisor

\section{Professor Dr. Dr. h. c. mult. H. W. Roesky}

for his constant guidance, motivation, suggestions, and discussion throughout this work.

I thank Mr. D. Stern, Prof. D. Stalke, Dr. G. Schwab, and Prof. C. Schulzke for their help in the X-ray crystal structural investigations and refinement of disordered molecules and twinned crystals. I thank Mr. W. Zolke, Mr. R. Schöne, Dr. M. John (NMR spectra), Dr. D. Böhler, Mr. T. Schuchardt, Mr. J. Schöne (mass spectra), Mr. M. Hesse (IR spectra), Mr. J. Schimkowiak, Mr. M. Schlote, and the staff of the Analytical Laboratories, and Werkstatt for their timely support during this research work. I am also thankful to all the members of glass blowing section, work shop, chemical store as well the security of our institute for their cooperation and help in all kind of situations.

I am grateful to Dr. A. Jana, Mr. S. S. Sen, Mr. Z. Zhang, Mr. A. Döring, Dr. S. Nembenna, Dr. R. S. Ghadwal, Dr. S. K. Mandal, Dr. Y. Ying, and Dr. V. M. Jimenez-Perez.

My special thanks to S. P. Sarish, P. P. Samuel, and P. M. Guru, for their friendliness and help during my stay at Göttingen.

The full support and encouragement from my parents, family and friends made this work possible. 
Table of Contents

1. Introduction........................................... 1

1.1. Organobismuth(III) Compounds................................. 1

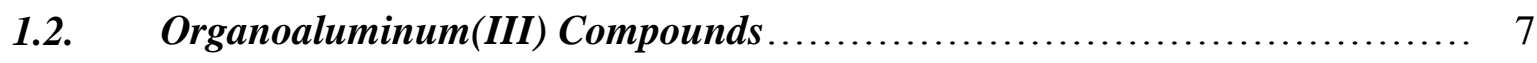

1.3. Aims and Objectives of the Present Work............................. 11

2. Results and Discussion .............................................. 12

2.1. Bismuthamidation of Unsaturated Organic Compounds................... 12

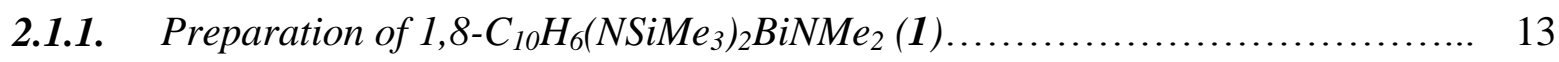

2.1.2. Reaction of $\mathrm{L}^{\mathrm{l} B i N M e_{2}}$ (1) with Ketone and Aldehyde: Synthesis of

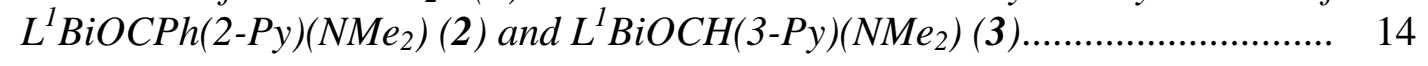

2.1.3. Reaction of $\mathrm{L}^{1} \mathrm{BiNMe}_{2}$ (1) with Alkene and Alkine: Synthesis of $\mathrm{L}^{1} \mathrm{BiC}(\mathrm{Me})(\mathrm{CN}) \mathrm{CH}_{2} \mathrm{NMe}_{2}(\mathbf{4})$ and $\mathrm{L}^{1} \mathrm{BiC}\left(\mathrm{CO}_{2} \mathrm{Et}\right) \mathrm{CNMe}_{2}\left(\mathrm{CONMe}_{2}\right)($ (5)........ 18

2.1.4. Reaction of $L^{l} B^{B N M e_{2}}$ (1) with $N, N^{\prime}$-Diisopropylcarbodiimide: Synthesis of

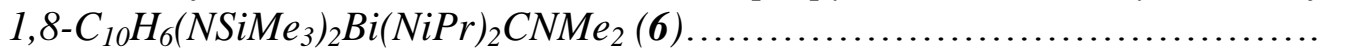

2.1.5. Reaction of $\mathrm{L}^{1} \mathrm{BiNMe}_{2}$ (1) with Phenylisocyanate: Synthesis of 1,8-

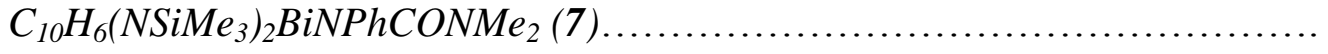

2.2. Heterobimetallic Bismuth Complexes with Main Group and Transition Metals.

2.2.1. Reaction of $\mathrm{L}^{1} \mathrm{BiNMe}_{2}$ (1) with $\mathrm{LM}(\mathrm{Me})(\mathrm{OH})$ : Synthesis of 1,8

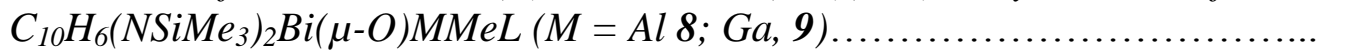

2.2.2. Reaction of $\mathrm{L}^{1} \mathrm{BiNMe}_{2}$ (1) with LGe(OH): Synthesis of 1,8-

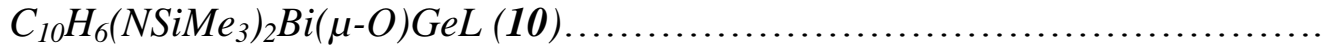

2.2.3. Reaction of $\mathrm{LB}^{\mathrm{l}} \mathrm{BiNMe}_{2}$ (1) with $\mathrm{Cp}_{2}{ }_{2} \mathrm{MR}(\mathrm{OH})$ : Synthesis of 1,8$\mathrm{C}_{10} \mathrm{H}_{6}\left(\mathrm{NSiMe}_{3}\right)_{2} \mathrm{Bi}(\mu-\mathrm{O}) \mathrm{MRCp}_{2}{ }_{2}(\mathrm{M}=\mathrm{Zr} \mathrm{11}, \mathrm{R}=\mathrm{Me} ; \mathrm{Hf}, \mathrm{12}, \mathrm{R}=\mathrm{Cl}) \ldots \ldots \ldots \ldots$

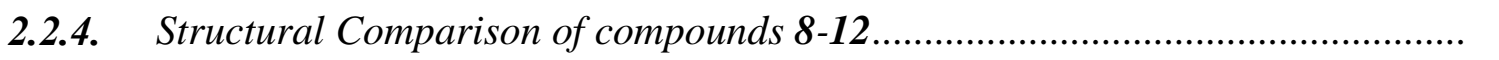

2.3. Synthesis, Structure and Reactivity of Organobismuth(III), Bismuth Chalcogenide and Dibismuthine Complexes.

2.3.1. Synthesis, Spectroscopic Characterization and Structure of Complexes [1,8$\left.\mathrm{C}_{10} \mathrm{H}_{6}\left(\mathrm{NSiMe}_{3}\right)_{2}\right] \mathrm{BiR} \quad\left(\mathrm{R}=\mathrm{Cl}(\mathbf{1 3}), \mathrm{CCPh}(\mathbf{1 4}), \mathrm{Cp}{ }^{*}(\mathbf{1 5}), \mathrm{Me}(\mathbf{1 6}), \mathrm{OPh}(\mathbf{1 7})\right.$, 
$\mathrm{NH}_{2}(18)$.

2.3.2. Molecular Structure Description of Compounds 13-16.

2.3.3. Synthesis, Spectroscopic Characterization and Structure of Organobismuth Chalcogenide Complex: Synthesis of [1,8- $\left.\mathrm{C}_{10} \mathrm{H}_{6}\left(\mathrm{NSiMe}_{3}\right)_{2} \mathrm{Bi}\right]_{2} \mathrm{~S}(19)$.

2.3.4. Synthesis, Spectroscopic Characterization and Structure of Low-valent Dibismuthine Complex: Synthesis of $\left[1,8-\mathrm{C}_{10} \mathrm{H}_{6}\left(\mathrm{NSiMe}_{3}\right)_{2} \mathrm{Bi}\right]_{2}(20)$

2.4. Synthesis, Characterization, and X-ray Single Crystal Structures of $N, N^{\prime}-$ Bis(trimethylsilyl)diphenyliminophosphonamide Aluminum Halide, Hydride, Amide and Alkylate.

2.4.1. Synthesis of $\mathrm{Ph}_{2} \mathrm{P}\left(\mathrm{NSiMe}_{3}\right)_{2} \mathrm{Li}$ (22).

2.4.2. Reaction of $L^{2} \mathrm{Li}$ with $\mathrm{RAlCl}_{2}$ : Synthesis of $\mathrm{Ph}_{2} \mathrm{P}\left(\mathrm{NSiMe}_{3}\right)_{2} \mathrm{AlRCl}(\mathrm{R}=\mathrm{Cl}, 23$; $\mathrm{Me}, 24)$.

2.4.3. Reaction of $\mathrm{L}^{2} \mathrm{H}$ with $\mathrm{AlH}_{3} \cdot \mathrm{NMe}_{3}$ : Synthesis of $\left[\mathrm{Ph}_{2} \mathrm{P}\left(\mathrm{NSiMe}_{3}\right)_{2}\right]_{2} \mathrm{AlH}(\mathbf{2 5}) \ldots \ldots$ 50

2.4.4. Reaction of $\mathrm{L}^{2} \mathrm{H}$ with $\mathrm{AlEt}_{3}$ and $\left[\mathrm{Al}\left(\mathrm{NMe}_{2}\right)_{3}\right]_{2}$ : Synthesis of $\mathrm{Ph}_{2} \mathrm{P}\left(\mathrm{NSiMe}_{3}\right)_{2} \mathrm{AlEt}_{2}(26)$ and $\mathrm{Ph}_{2} \mathrm{P}\left(\mathrm{NSiMe}_{3}\right)_{2} \mathrm{Al}\left(\mathrm{NMe}_{2}\right)_{2}$ (27).

2.4.5. Structural Comparison of $\mathrm{L}^{2} \mathrm{AlCl}_{2}$ (23), $\mathrm{L}^{2} \mathrm{AlMeCl}(\mathbf{2 4}), \mathrm{L}_{2}^{2} \mathrm{AlH}$ (25), and $\mathrm{L}^{2} \mathrm{Al}\left(\mathrm{NMe}_{2}\right)_{2}(\mathbf{2 7})$

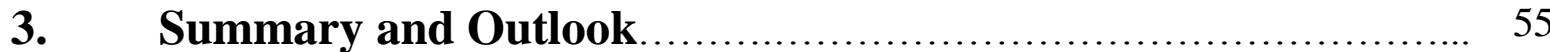

3.1. Summary.......................................................... 55

3.2. Outlook................................................................ 61

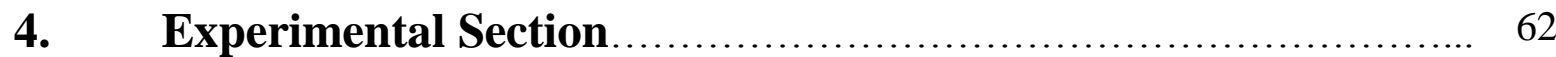

4.1. General Procedures.................................................... 62

4.2. Physical Measurements............................................... 62

4.3. $\quad$ Starting Materials...................................................... 63

4.4. Synthesis...................................................... 63

5. Handling and Disposal of Solvents and Residual Waste 


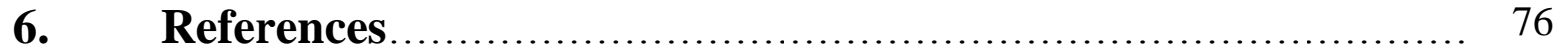

List of Publications............................................................................ 


\section{Abbreviations}

av

Ar

br

$t \mathrm{Bu}$

C

calcd

$\mathrm{Cp}$

$\mathrm{Cp} *$

d

dec

$\delta$

EI

g

$i \operatorname{Pr}$

IR

h

$\eta$

$\mathrm{Hz}$

$\lambda$

$\mathrm{M}^{+}$

$m / z$

M.p.

$\mu$

NMR

ppm
Average

Aryl

Broad

tert-butyl

Celsius

calculated

cyclopentadienyl

pentamethylcyclopentadienyl

doublet

decomposition

chemical shift

electron impact ionization

grams

isopropyl

infrared

hour(s)

hapto

Hertz

wavelength

molecular ion

mass/charge

melting point

bridging

nuclear magnetic resonance

parts per million 
quartet

RT

room temperature

S

singlet

sept

septet

$\mathrm{t}$

triplet

THF

tetrahydrofuran

TMS

tetramethylsilane

V

Volume

$\tilde{v}$

Wave number

Z

number of molecules in the unit cell

$\mathrm{L}$

$\mathrm{CH}((\mathrm{CMe}) \mathrm{NAr})_{2}, \mathrm{Ar}=2,6-i \mathrm{Pr}_{2} \mathrm{C}_{6} \mathrm{H}_{3}$

$\mathrm{L}^{1}$

$1,8-\mathrm{C}_{10} \mathrm{H}_{6}\left(\mathrm{NSiMe}_{3}\right)_{2}$

$\mathrm{L}^{2}$

$\mathrm{Ph}_{2} \mathrm{P}\left(\mathrm{NSiMe}_{3}\right)_{2}$ 


\section{Introduction}

This section of the thesis gives the background and an overview of the area in two sections before the present work is put forwared.

\subsection{Organobismuth(III) Compounds}

Bismuth was first mentioned in the 1450s as Wismutton or Bisemutun, probably derived from the old German word Weissmuth or Wismut, meaning white substances. Bismuth, Bi, the $83^{\text {rd }}$ element of the periodic table is the most metallic and the least abundant of the elements in the nitrogen family (group 15). The bismuth atom with a ground state electronic configuration of [Xe] $4 f^{14} 5 d^{10} 6 s^{2} 6 p^{3}$ usually utilizes the three $6 p$ electrons in bond formation and retains the two $6 s$ electrons as an inert pair, hence the oxidation state +3 exhibited bismuth in the vast majority of its compounds. However, a variety of organobismuth compounds can contain the element in the +5 oxidation state. Coordination numbers are 2,3 , 4, 5 and 6 . It is the heaviest member of group 15 and the heaviest stable element in the periodic table. Although it belongs to the group 15 family, the chemistry of bismuth differs considerably from that of other lighter members, such as phosphorus, arsenic and antimony. Elemental bismuth is inert in dry air at room temperature, but oxidizes slowly to become covered with a thin film of the oxide. Bismuth compounds are attracting increasing attention due to their application in heterogeneous catalysis, ${ }^{1}$ catalysts for organic synthesis, ${ }^{2}$ superconducting materials, ${ }^{3}$ and also biological activity.

Bismuth amides, $\mathrm{Bi}\left(\mathrm{NRR}^{\prime}\right)_{3}$, are a series of compounds that have covalent $\mathrm{Bi}-\mathrm{N}$ bonds $(\mathrm{R}$ and $\mathrm{R}^{\prime}$ can be alkyl, aryl or silyl groups). These compounds can be promising precursors for bismuth oxide based materials ${ }^{4,5}$ and have been used as precursors for metal-organic chemical vapor deposition (MOCVD) of bismuth-containing thin films due to their low M-N bond strength. ${ }^{6}$ Relatively few bismuth amides with sterically crowded substituents are known. The 


\section{Introduction}

reported bismuth amides were synthesized by reaction of the lithium amide salt with a bismuth halide (Scheme 1).

\section{Scheme 1}

$$
\begin{aligned}
& \text { LiNRR' }^{+} \mathrm{R}_{n}{ }^{\prime B i X}{ }_{3-n} \longrightarrow \mathrm{R}^{\prime \prime}{ }_{n} \mathrm{Bi}\left(\mathrm{NRR}^{\prime}\right)_{3-\mathrm{n}} \\
& \mathrm{R} \text { and } \mathrm{R}^{\prime} \text { = alkyl, aryl or silyl } \quad \mathrm{R}^{\prime \prime}=\text { alkyl } \quad \mathrm{LiX}=0,1 \text {, or } 2
\end{aligned}
$$

Depending on the different $\mathrm{R}$ and $\mathrm{R}^{\prime}$ groups, bismuth amides $\mathrm{Bi}\left(\mathrm{NRR} \mathrm{R}_{3}\right.$ have varying properties. When $\mathrm{R}$ and $\mathrm{R}^{\prime}$ are alkyl groups $\left(\mathrm{R}=\mathrm{R}^{\prime}=\mathrm{Me}\right.$, Et, or $\left.\mathrm{Pr}\right)$, bismuth amides are air sensitive and thermosensitive. ${ }^{7}$ In the preparation of these simple alkyl bismuth amides, the use of THF as solvent is indispensable; all attempts in hexane, cyclohexane, petroleum ether and ether failed. These amides gradually turn jet black at room temperature; however, they can be stored indefinitely at dry ice temperature. All of these bismuth amides are volatile. The best conditions for sublimation of $\mathrm{Bi}\left(\mathrm{NMe}_{2}\right)_{3}$ are using a pressure of about $10^{-2} \mathrm{mbar}$ and warming the flask to $30{ }^{\circ} \mathrm{C}$. $\mathrm{Bi}\left(\mathrm{NMe}_{2}\right)_{3}$ is light sensitive and with exposure to bright sunlight it will turn black. For $\mathrm{R}=$ aryl, both the compounds with simple phenyl group and substituted phenyl groups have been reported. When $\mathrm{R}=\mathrm{R}^{\prime}=\mathrm{Ph}$, the bismuth amide is soluble in toluene, THF and $\mathrm{CH}_{2} \mathrm{Cl}_{2}$ and is very sensitive to traces of moisture. When $\mathrm{Li}(\mathrm{NRH})$ was used $\left(\mathrm{R}=2,6-\mathrm{Me}_{2} \mathrm{C}_{6} \mathrm{H}_{3}\right)$, a trinuclear complex $\left[\mathrm{Bi}_{3}(\mu-\mathrm{NR})_{4}(\mathrm{NHR})\right]$ was characterized by single crystal X-ray diffraction. ${ }^{8}$ A pure sample of this compound could not be obtained due to contamination by other unidentified complexes. When the steric bulk was increased by introducing ortho isopropyl substituents on the phenyl groups, a bismuth amide with a cyclic dimeric structure was obtained (Scheme 2). ${ }^{9}$ 


\section{Scheme 2}

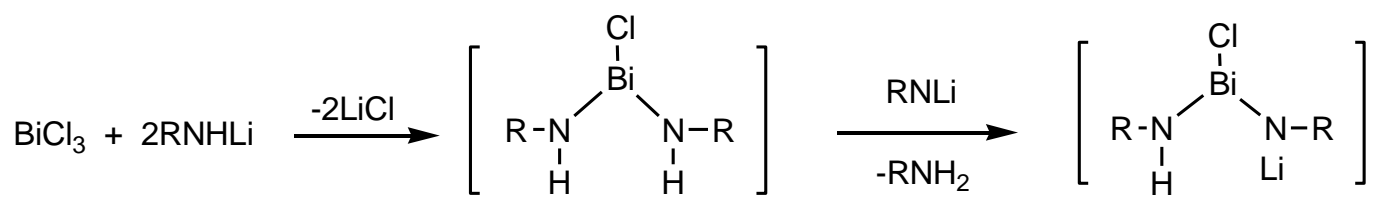

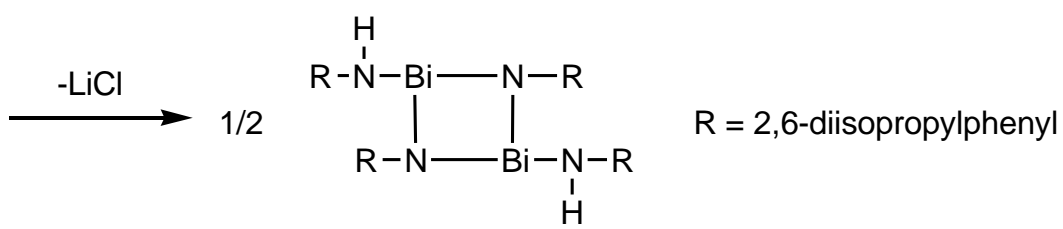

When $\operatorname{Li}(\mathrm{NHR})$ ( $\mathrm{R}=$ 2,4,6-tri-tert-butylphenyl) was used, the steric bulk was further increased and monomeric $\mathrm{Bi}\left[\mathrm{N}(\mathrm{H})\left(\mathrm{C}_{6} \mathrm{H}_{2} t \mathrm{Bu}_{3}\right)\right]_{3}$ was obtained. ${ }^{10}$ Burford et al. pointed out that the monomeric compounds $\mathrm{Bi}\left[\mathrm{N}(\mathrm{H})\left(\mathrm{C}_{6} \mathrm{H}_{2} t \mathrm{Bu}_{3}\right)\right]_{3}$ and $\mathrm{Bi}\left[\mathrm{N}(\mathrm{H})\left(\mathrm{C}_{6} \mathrm{H}_{3} i \mathrm{Pr}_{2}\right)\right]_{3}$ should form first, and then the corresponding dimers will form. ${ }^{10}$ They suggested a different mechanism (Scheme 3) to account for the formation of the dimer $[\operatorname{RNBi}(\mathrm{NHR})]_{2}, \quad \mathrm{R}=2,6-$ diisopropylphenyl, through the bismazene intermediate A. James et al. also believe that their trinuclear complex $\left[\mathrm{Bi}_{3}(\mu-\mathrm{NR})_{4}(\mathrm{NHR})\right]$ is formed from the corresponding tricoordinate compound by elimination of the amine. ${ }^{8}$

\section{Scheme 3}

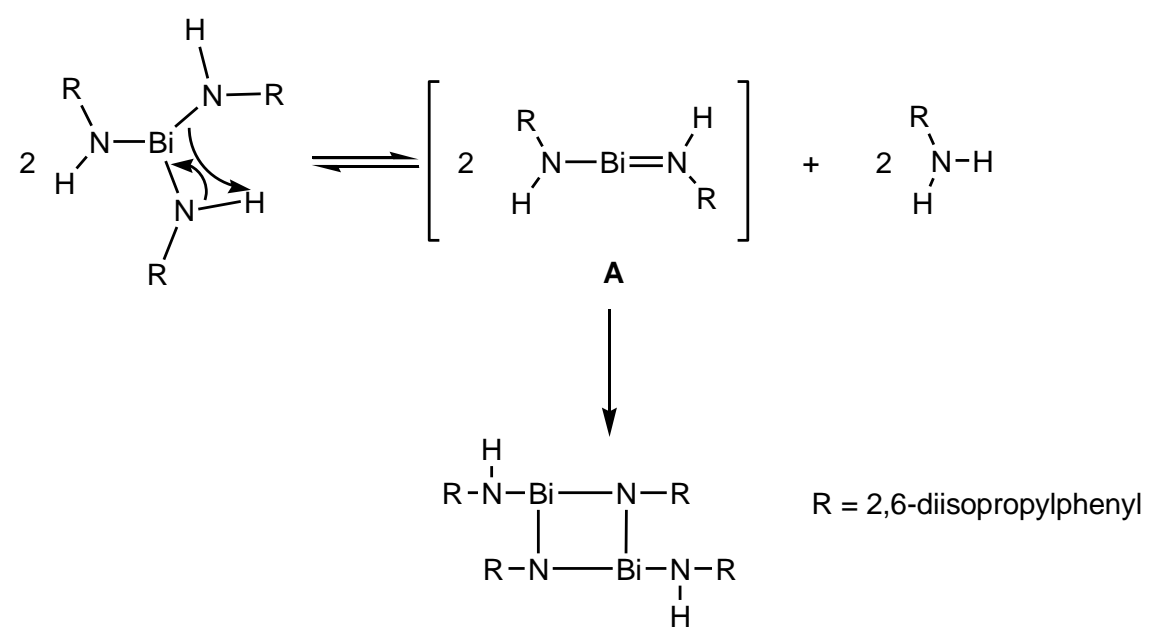

Bismuth silylamides, $\mathrm{Bi}\left(\mathrm{NRR}^{\prime}\right)_{3}\left(\mathrm{R}=\mathrm{SiMe}_{3}\right)$, have also been reported. A series of monosilylated bismuth amides $\left(\mathrm{Me}_{2} \mathrm{Bi}\left[\mathrm{NMe}\left(\mathrm{SiMe}_{3}\right)\right], \quad \mathrm{MeBi}\left[\mathrm{NMe}\left(\mathrm{SiMe}_{3}\right)\right]_{2}, \quad\right.$ and $\left.\operatorname{Bi}\left[\mathrm{NMe}\left(\mathrm{SiMe}_{3}\right)\right]_{3}\right)$ were first reported by Scherer et al. ${ }^{11}$ The corresponding disilylated 


\section{Introduction}

derivative, $\mathrm{Bi}\left[\mathrm{N}\left(\mathrm{SiMe}_{3}\right)_{2}\right]_{3}$, was later reported by Lappert et al. ${ }^{12}$ All of these bismuth amides have been characterized spectroscopically but without X-ray structure determinations. $\mathrm{Me}_{2} \mathrm{Bi}\left[\mathrm{NMe}\left(\mathrm{SiMe}_{3}\right)\right]$ and $\mathrm{MeBi}\left[\mathrm{NMe}\left(\mathrm{SiMe}_{3}\right)\right]_{2}$ are liquids; $\mathrm{Bi}\left[\mathrm{NMe}\left(\mathrm{SiMe}_{3}\right)\right]_{3}$ has a melting point of $27-29{ }^{\circ} \mathrm{C}$; and $\mathrm{Bi}\left[\mathrm{NMe}\left(\mathrm{SiMe}_{3}\right)\right]_{3}$ has a melting point around $90{ }^{\circ} \mathrm{C}$ (decomposition). Veith et al. obtained $\mathrm{Bi}_{2}\left[(\mathrm{~N} t \mathrm{Bu})_{2} \mathrm{SiMe}_{2}\right]_{3}$ (Scheme 4) starting from the lithium salt of the diamine $\left(t \mathrm{BuN}(\mathrm{H})-\mathrm{SiMe}_{2}-\mathrm{N}(\mathrm{H}) t \mathrm{Bu}\right){ }^{13}$ If the ratio of $\mathrm{BiCl}_{3}$ and the lithium salt is $1: 1$, the corresponding bismuth chlorine compound $\left[\mathrm{Me}_{2} \mathrm{Si}(\mathrm{N} t \mathrm{Bu})_{2} \mathrm{Bi}\right] \mathrm{Cl}$ (Scheme 4) can also be isolated.

\section{Scheme 4}
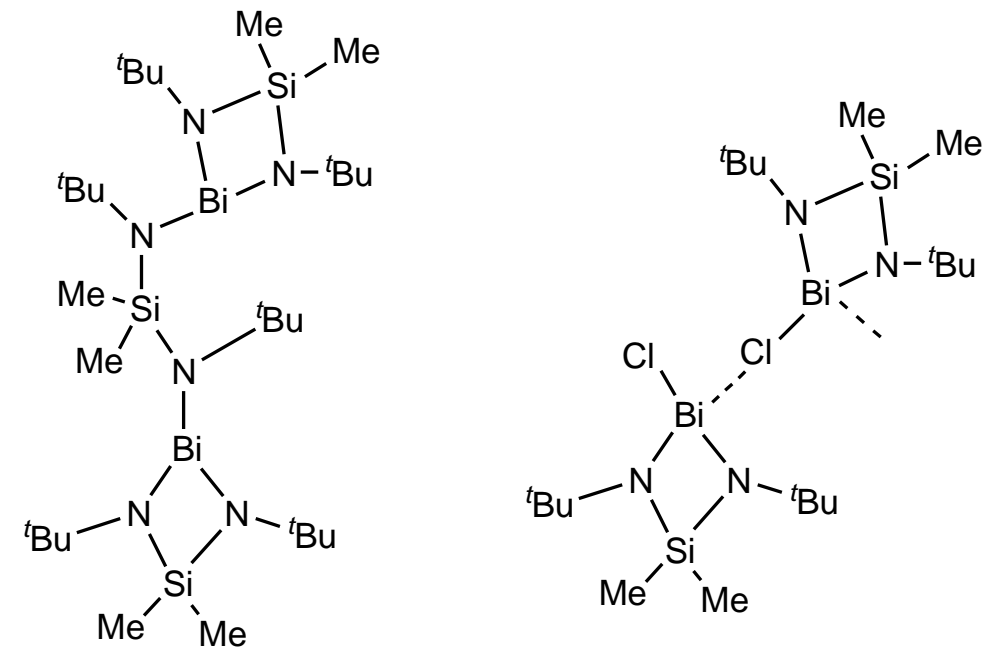

$$
\mathrm{Bi}_{2}\left[(\mathrm{~N} t \mathrm{Bu})_{2} \mathrm{SiMe}_{2}\right]_{3}
$$

$\left[\mathrm{Me}_{2} \mathrm{Si}(\mathrm{N} t \mathrm{Bu})_{2} \mathrm{Bi}\right] \mathrm{Cl}$

Metal-amido complexes have been proposed as key intermediates in important catalytic processes and especially in the fixation and activation of nitrogen. ${ }^{14}$ Insertion reactions of carbonyl and alkene compounds into metal nitrogen bonds have been known for lanthanides and early and late transition metals complexes. However, the insertion of carbon-carbon, carbon-oxygen and carbon-nitrogen bonds into the metal-nitrogen bond has not well been studied with main-group compounds. This may be due the poor reactivity of compounds with nitrogen bonds. Lappert et al. described the addition of amminostannanes to a variety of 


\section{Introduction}

alkines and alkenes. ${ }^{15}$ They also reported amminosilylation and aminophosphination reactions with highly electrophilic substrates. ${ }^{16}$ Recently Hartwig and coworkers reported transammination of alkenes and vinylarenes by rhodium (I) amides. ${ }^{17}$ The insertion of alkine into a molybdenum amid bond has also been described. ${ }^{18}$

The design and synthesis of heterobimetallic bismuth complexes with a stoichiometry appropriate for use as direct precursors for advanced materials is an ambitious challenge. The coordination chemistry of all of the heavy main group elements, and bismuth in particular, is complicated by the high latent Lewis acidity of the metal center combined with its ability to easily expand its coordination sphere. Most work has concentrated on bimetallic systems which possess bridging ligands coordinated to two contiguous metals. ${ }^{19-23}$ Other constructions involve tethering two metal complexes by non-coordinating links. ${ }^{24-26}$ Metals may be linked by one $(\mathbf{1}),{ }^{27-29}$ two $(\mathbf{2})^{30-33}$ or three $(\mathbf{3})^{34-36}$ bridging groups of which the most prevalent is the two-bridge system 2.

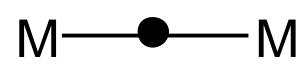

1

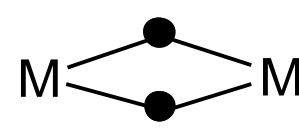

2

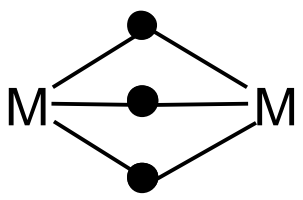

3

In reviewing literature, several general routes to the formation of heterobimetallic coordination complexes can be surmised. ${ }^{37}$ Specifically, these are salt metathesis reactions, volatile elimination reactions, bifunctional ligands, Lewis acid-base adduct formation and alkali metal reduction. Not all of these synthetic approaches are available for the development of precursors for advanced oxide materials. Significant efforts have been made to develop solution-based routes to the formation of oxide based materials, and numerous solution-based approaches for the formation of bi- or multimetallic oxide systems have been reported including sol-gel, metal organic decomposition (MOD) routes. These methods have been used successfully to produce numerous heterobimetallic systems. It has been reported that oxides 


\section{Introduction}

synthesized by these approaches have properties that are superior to those produced in solidstate reactions. ${ }^{38}$ Further, it has also been observed that the properties of many oxides produced by wet chemical routes, including the reactivity of material and conditions required for crystallization of the phase, are sensitive to the manner in which the different metal precursors are brought together prior to decomposition. ${ }^{39}$ Recently these complexes have attracted increasing interest due to their potential applications as high $T_{c}$ superconductors, ${ }^{40}$ in nonlinear optics, ${ }^{41}$ in oxidation reactions, as catalysts, ${ }^{42}$ and as thermoelectric and ferroelectric materials. It has been observed that the bismuth germanium oxide system is the best candidate for electro-optic voltage sensors ${ }^{43}$ and the mixed oxides of aluminum and bismuth show high oxide-ion conductivity. ${ }^{44}$

Bismuth chalcogenides are an interesting class of compounds with amazing structural and compositional complexity. The stereochemical activity of the $6 s^{2}$ lone pair of electrons of Bi influences the structures, and thus the properties of the compounds. Diorganobismuth chalcogenides of the type $\left(\mathrm{R}_{2} \mathrm{Bi}\right)_{2} \mathrm{X}(\mathrm{X}=$ chalcogen, $\mathrm{R}=$ alkyl, aryl $)$ have been under investigation for a long time but little is known about their structural chemistry. These compounds are of interest as potential precursors for semiconducting bismuth chalcogenides, $\mathrm{Bi}_{2} \mathrm{E}_{3}(\mathrm{E}=$ chalcogen $)$, and therefore they can display interesting molecular and supramolecular architectures. Several well-defined organobismuth chalcogenides have been synthesized and their crystal structures were determined such as $\left(\mathrm{R}_{2} \mathrm{Bi}\right)_{2} \mathrm{E}[\mathrm{R}=\mathrm{Mes}, \mathrm{E}=\mathrm{O}, \mathrm{S}, \mathrm{Se}]{ }^{45}$

Dibismuthines $\mathrm{R}_{2} \mathrm{BiBiR}_{2}$ are a type of compound which contain a bismuth-bismuth bond. $\mathrm{R}$ can be an alkyl group $\left(\mathrm{HC}\left(\mathrm{Me}_{3} \mathrm{Si}\right)_{2},{ }^{46} \mathrm{Me}, \mathrm{Et}, \mathrm{Pr}, \mathrm{Bu}\right.$, or $\left.{ }^{\mathrm{i}} \mathrm{Pr}^{47}\right)$, or an alkene or aromatic group $\left(\mathrm{CH}_{2}=\mathrm{C}\left(\mathrm{CH}_{3}\right)-{ }^{47}\left(\mathrm{CH}_{3}\right)_{2} \mathrm{C}=\mathrm{CH}-,{ }^{47} \mathrm{Ph},{ }^{48}\right.$ 2,4,6-trimethyphenyl, ${ }^{49} 2-\left(\mathrm{Me}_{2} \mathrm{NCH}_{2}\right) \mathrm{C}_{6} \mathrm{H}_{4},{ }^{50}$ 2,6- $\left(\mathrm{Me}_{2} \mathrm{NCH}_{2}\right)_{2} \mathrm{C}_{6} \mathrm{H}_{3},{ }^{51}$ or $p$-methylphenyl $\left.{ }^{52}\right)$. They have characteristic physical and chemical properties due to the Bi-Bi bond. ${ }^{53}$ The most interesting is thermochromism: when melted or dissolved in organic solvents, some dibismuthines show drastic color changes. Recent studies have revealed that the intermolecular $\mathrm{Bi} \cdots \mathrm{Bi}$ interaction of dibismuthines in solid state has a 


\section{Introduction}

significant influence on this phenomenon. ${ }^{54}$ The $\mathrm{Bi}-\mathrm{Bi}$ bond is cleaved easily by the attack of various reagents. Bismuth atoms may also be included in ring systems $R_{2} B i B i R_{2}$, where $R_{2}$ groups are $(\mathrm{CMe}=\mathrm{CH})_{2}{ }^{55}$ or $\left(\mathrm{CH}_{2} \mathrm{CH}_{2}\right)_{2}{ }^{47}$. Oligomeric organylbismuth $(\mathrm{I})$ compounds, $(\mathrm{RBi})_{3}$ and $(\mathrm{RBi})_{4}$ are also reported. They form small ring structures with $\mathrm{Bi}-\mathrm{Bi}$ bonds, and there is an equilibrium between two compounds in solution. ${ }^{56}$

The coordination geometry around bismuth atoms is basically pyramidal (Scheme $5, \mathrm{Y}=$ $\mathrm{R}, \mathrm{Bi} ; \mathrm{M}=\mathrm{Bi}(\mathbf{I})$ ) for three coordinate compounds, with possibilities for an increase of the coordination number through intermolecular $\mathrm{Bi} \cdots \mathrm{Bi}$ interactions leading to a trigonal bipyramidal environment (Scheme 5, II).

\section{Scheme 5}

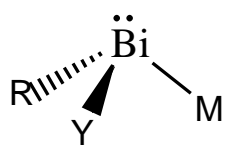

I<smiles></smiles>

II

\subsection{Organoaluminum(III) Compounds}

Aluminum is the most abundant metal in the Earth's crust and as such its chemistry has been studied for many years. The metal itself and its alloys are employed for a wide variety of uses in the building and transportation industries. Because of the diversity displayed by aluminum compounds, their applications span many disciplines, from material science and electronics to catalysis. Several applications include the use of alkoxides as precursors in solgel processes,${ }^{57}$ the halides as Lewis acid catalysts, ${ }^{58}$ the hydrides as reducing agents in organic synthesis, ${ }^{59,60}$ and the nitrate salts for water treatment. ${ }^{61}$ The alkyl derivatives of aluminum play very important roles as co-catalysts or precursors to co-catalysts in ZieglerNatta polymerization of olefins. 


\section{Introduction}

The importance of organoaluminum compounds is due to their use in a variety of applications, including organic synthesis and industrial catalytic processes. They have also been utilized as precursors in chemical vapor deposition (CVD) processes. ${ }^{62}$ Compounds such as hexakis(dimethylamido)dialuminum, $\mathrm{Al}_{2}\left(\mathrm{NMe}_{2}\right)_{6},{ }^{63-65}$ azides of formula $\left(\mathrm{R}_{2} \mathrm{AlN}_{3}\right)_{3}(\mathrm{R}=$ Me or Et $)^{66-68}$ and amides of formula $\left(\mathrm{R}_{2}^{1} \mathrm{AlNR}_{2}{ }_{2}\right)_{n}\left(\mathrm{R}^{1}=\mathrm{Me} ; \mathrm{R}^{2}=\mathrm{H}\right.$, Me or $i \mathrm{Pr} ; n=2$ or $3)^{69,70}$ have been used to deposit polycrystalline AlN films, although an atmosphere of ammonia is required to obtain good-quality material. In polymerization catalysis, main group compounds play important roles as activators in the generation of cationic transition-metal alkyl species that polymerize $\alpha$-olefins. ${ }^{71}$ It has been observed that stable aluminum compounds involving nitrogen substituents or neutral nitrogen donors are useful in the preparation of aluminum nitrides, AlN based semiconductors, and AlN ceramics. ${ }^{72-74}$ The chemistry of compounds containing AlN bonds has flourished over the past several years due mainly to current interest in developing optimum AlN precursors. ${ }^{75,76}$ Earlier work on the structures and properties of the alkyl aluminum amides has focused largely on the alkyl and arylamine derivatives $\mathrm{R}_{2} \mathrm{AlNR} \mathrm{R}^{\prime \prime}$ where both $\mathrm{R}^{\prime}$ and $\mathrm{R}^{\prime \prime}$ are organic groups or where one of these substituents is hydrogen. These aluminum derivatives show a strong tendency to oligomerize due to the Lewis acidity of the aluminum center and to the presence of the electron lone pair of the amido group. The steric bulk of the substituents is the major factor that determines the degree of association..$^{77}$ Therefore, these compounds are generally found in the form of oligomers of the type $\left[\mathrm{R}_{2} \mathrm{AlNR}^{\prime} \mathrm{R}^{\prime \prime}\right]_{\mathrm{n}}$ with either four- $(n=2)$ or six-membered $(N=3)(\mathrm{AlN})_{\mathrm{n}}$ rings. Alkylaluminum amides have a very rich and diverse structural chemistry. When a trialkyalane reacts with primary or secondary amines, the amides $\mathbf{A}, \mathbf{B}$, and $\mathbf{C}$ are formed in addition to simple adducts (Schemes 6, 7). Compounds of type $\mathbf{A}$ or $\mathbf{B}$ are cyclic and those of type $\mathbf{C}$ are polycyclic, as shown by spectroscopic data or X-ray structure determinations. $\left(\mathrm{Me}_{2}-\mathrm{AlNMe}_{2}\right)_{2}$ forms a planar four-membered cycle ${ }^{78}$ but $\left(\mathrm{Me}_{2} \mathrm{AlNHMe}\right)_{3}$ 


\section{Introduction}

has a six-membered $\mathrm{Al}_{3} \mathrm{~N}_{3}$ ring. ${ }^{79}$ The polycyclic oligomers (RAINR) (type $\mathbf{C}$ compounds) may adopt an $\mathrm{Al}_{n}-\mathrm{N}_{\mathrm{n}}$ skeleton that resemble either a cube $(\mathrm{n}=4)$ or a hexagonal prism $(\mathrm{n}=6)$

Scheme 6

$$
\mathrm{R}_{3} \mathrm{Al}+\mathrm{H}_{2} \mathrm{~N}-\mathrm{R}
$$

$-\mathrm{RH}$

$1 / n\left(R_{2} A l-N H R\right)_{n}$

A

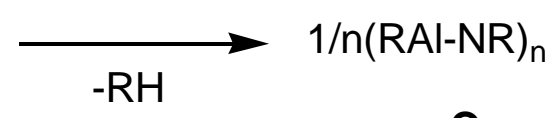

C

\section{Scheme 7}

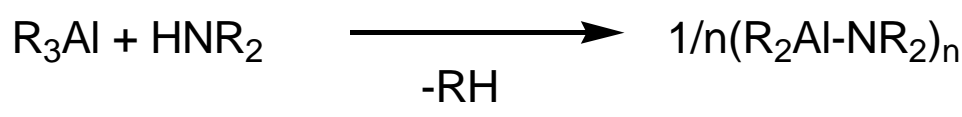

B

As in the compounds of type $\mathbf{A}$ or $\mathbf{B}$, both the aluminum and nitrogen atoms always have the coordination number four. When the substituents on the secondary amine in Scheme 7 are bulky or when trimethylsilyl groups are employed, compounds are isolated that have only one amide function in the product (Scheme $\left.8, \mathrm{R}=\mathrm{Ph}, \mathrm{SiMe}_{3}\right) .{ }^{80}$

\section{Scheme 8}

$$
\left[\mathrm{Me}_{3} \mathrm{Al}\right]_{2}+\mathrm{HNR}_{2}
$$

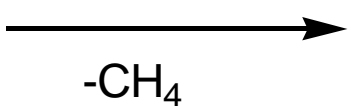

$\mathrm{Me}_{3} \mathrm{Al} \cdot \mathrm{Me}_{2} \mathrm{AINR}_{2}$

There are, however, only a few examples known of monomeric aluminum amides in addition to compounds of type $\mathbf{A}$ and $\mathbf{B}$, some of which have been claimed to be monomeric [e.g. $\left.\mathrm{Me}_{2} \mathrm{AlN}\left(\mathrm{SiEt}_{3}\right)_{2}, \mathrm{Me}_{2} \mathrm{Al}-\mathrm{NPhSiMe}\right]_{3}{ }^{80,81}$

Particularly, there has been immense research interest in synthesizing aluminum chlorides and methyl derivatives which can act as precursors for heterobimetallic complexes and aluminum hydrides which can be useful for preparing aluminum chalcogenides of the formula $(\mathrm{RAlE})_{n}(\mathrm{R}=\text { organic ligand; } \mathrm{E}=\mathrm{S}, \mathrm{Se}, \mathrm{Te} ; n=2,4)^{82}$, and also can be used for preparing 


\section{Introduction}

aluminum containing heteroatom rings ${ }^{83}$ by $\mathrm{H}_{2}$ elimination reactions. Aluminum alkyls can be converted to aluminum halides or aluminum oxides. Recently a series of aluminum oxides and aluminum hydroxides were synthesized by the hydrolysis reaction of aluminum alkyls. ${ }^{84}$ 


\subsection{Aims and Scope of the Present Work}

As discussed above, organobismuth and organoaluminum compounds have been widely investigated as cocatalysts, reagents as well as precursors for material science and industrial application. The aim of this thesis is the following by using the appropriate ligand system:

- To synthesize bismuthamide complex and investigate its property and reaction with compounds containing unsaturated $\mathrm{C}-\mathrm{O}, \mathrm{C}-\mathrm{C}$, and $\mathrm{C}-\mathrm{N}$ bonds;

- To use this species as a synthon to assemble a variety of heterobimetallic, chalcogenide and low-valent systems for potential application;

- To use spectral methods such as NMR spectroscopy, IR spectroscopy and X-ray structural analysis to unambiguously characterize the products obtained;

- To synthesize aluminum compounds stabilised by the iminophosphonamide ligand. 


\section{Results and Discussion}

\subsection{Bismuthamidation of Unsaturated Organic Compounds}

A bulky organic ligand is usually employed to stabilize the bismuth center electronically and/ or sterically. 1,8-Diaminonaphthalene ligands have been shown to be a very useful platform for the preparation of organometallic compounds with both transition and main group metals because the diamide ligand system generates a unique metallic center in terms of the geometry and the electronic property. In 1998, a series of new divalent bulky 1,8diaminonaphthalene ligands were reported, which are currently exhibiting growing interest due to their specific steric and electronic properties to control effectively the geometry at the metal center. The known complexes containing these ligands include main group (Al, Ge, In, $\mathrm{Li}, \mathrm{Mg}, \mathrm{Si}, \mathrm{Sn}, \mathrm{Tl})$ and transition metal $(\mathrm{Ni}, \mathrm{Ti}, \mathrm{Zr})$ derivatives. $^{85-88}$

The insertion of carbon-carbon, carbon-nitrogen and carbon-oxygen bonds into the bismuth-nitrogen bond has not well been studied. This may be attributed to the poor reactivity of compounds with nitrogen bonds. The only known compounds to this category are the reactions of bismuth amide with heterocumulenes by Ando et al. ${ }^{89}$ The work reported herein was fueled by the design and synthesis of main group complexes with the focus on their reactivity toward insertion reactions. We have recently reported the synthesis, structural characterization and reactions of tin(II) hydride species with compounds containing unsaturated $\mathrm{C}-\mathrm{O}, \mathrm{C}-\mathrm{C}$, and $\mathrm{C}-\mathrm{N}$ bonds, which resulted in simultaneous hydrogen and $\{\mathrm{LSn}\}$ transfer to the organic substrates. ${ }^{90}$ Herein we report the synthesis and structural characterization of a bismuth amide complex and its reaction with compounds containing unsaturated C-O, C-C, and C-N bonds. 


\subsubsection{Preparation of $1,8-\mathrm{C}_{10} \mathrm{H}_{6}\left(\mathrm{NSiMe}_{3}\right)_{2} \mathrm{BiNMe}_{2}(1)$}

Compound 1,8-bis[(trimethylsilyl)amino]naphthalene $\left(\mathrm{L}^{1} \mathrm{H}_{2}\right)$ was prepared by a previously reported method. ${ }^{88}$ The reaction of 1,8-bis[(trimethylsilyl)amino]naphthalene with $\mathrm{Bi}\left(\mathrm{NMe}_{2}\right)_{3}{ }^{6}$ in $n$-hexane at room temperature results in the formation of $\mathrm{L}^{1} \mathrm{BiNMe}_{2}(\mathbf{1})$ $\left[\mathrm{L}^{1}=1,8-\mathrm{C}_{10} \mathrm{H}_{6}\left(\mathrm{NSiMe}_{3}\right)_{2}\right]$ in good yield (Scheme 9). $\mathbf{1}$ is an orange solid, soluble in $n$-hexane, THF and toluene. Compound $\mathbf{1}$ is moderately air and moisture sensitive, and is slowly oxidized and hydrolyzed on exposure to air. It was characterized by multinuclear NMR, elemental analysis, and X-ray structural analysis. The ${ }^{1} \mathrm{H}$ NMR spectrum of $\mathbf{1}$ exhibits two singlets for the $\mathrm{SiMe}_{3}$ and $\mathrm{NMe}_{2}$ groups, respectively. ( $\delta 0.25$ and $\left.2.48 \mathrm{ppm}\right)$. The ${ }^{13} \mathrm{C} \mathrm{NMR}$ spectrum of 1 reveals two resonances ( $\delta 41.98,3.05 \mathrm{ppm})$, which can be assigned to the carbon resonances arising from $\mathrm{NMe}_{2}$ and $\mathrm{SiMe}_{3}$ groups, respectively. The ${ }^{29} \mathrm{Si} \mathrm{NMR}$ spectrum of 1 exhibits one singlet ( $\delta 3.306 \mathrm{ppm})$ attributed to the silicon resonances arising from $\mathrm{SiMe}_{3}$ groups.

\section{Scheme 9}
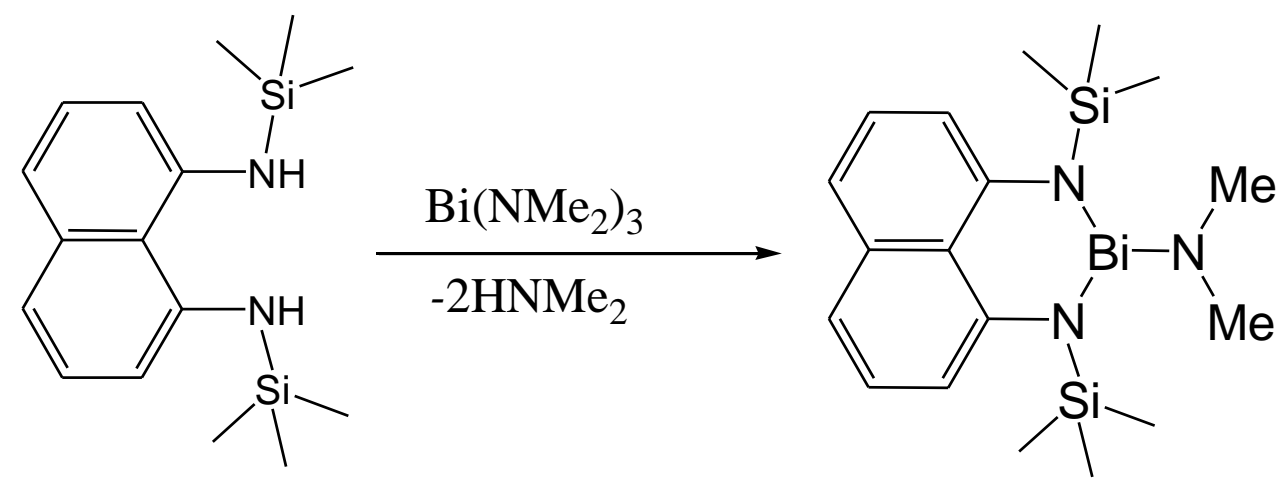

1

The molecular structure of $\mathrm{L}^{1} \mathrm{BiNMe}_{2}$ (1) has been determined by single crystal X-ray diffraction. 1 crystallizes in the monoclinic space group $P 2_{1} / n$ and the molecular structure (Figure 1) features a trigonal pyramidal coordinated bismuth atom. The $\mathrm{N}-\mathrm{Bi}-\mathrm{N}$ bond angles sum to $281.42^{\circ}$, hence prove the stereochemically active lone pair in the apical position. The 
Bi-N distances for $\mathbf{1}$ (average $2.168 \AA$ ) are comparable to those observed in structurally characterized $\mathrm{Bi}\left(\mathrm{NMe}_{2}\right)_{3},{ }^{6,91}$

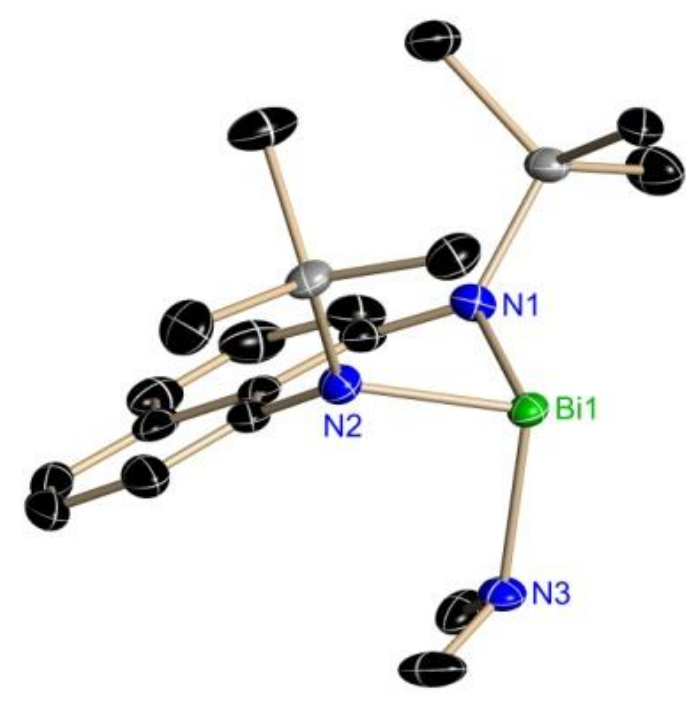

Figure 1. Crystal structure of 1, anisotropic displacement parameters depicted at the 50\% probability level. Hydrogen atoms are omitted for clarity. Selected bond lengths $[\AA]$ and angles []: Bi1-N1 2.150(1), Bi1-N2 2.176(1), Bi1-N3 2.179(1), N1-Bi1-N2 85.02(7), N1Bi1-N3 100.06(7), N2-Bi1-N3 96.34(6).

2.1.2. Reaction of $\mathrm{L}^{1} \mathrm{BiNMe}_{2}$ (1) with Ketone and Aldehyde: Synthesis of L BiOCPh(2$\mathrm{Py})\left(\mathrm{NMe}_{2}\right)$ (2) and $\mathrm{L}^{1} \mathrm{BiOCH}(3-\mathrm{Py})\left(\mathrm{NMe}_{2}\right)(3)$

The reaction of $\mathbf{1}$ with 2-benzoylpyridine proceeds smoothly at $25^{\circ} \mathrm{C}$ in $n$-hexane to give product 2 , which was subsequently isolated in $83 \%$ yield (Scheme 10 ). The ${ }^{1} \mathrm{H}$ and ${ }^{13} \mathrm{C}$ NMR spectra indicate the formation of an addition product in which 2-benzoylpyridine inserts into the Bi-N bond of $\mathbf{1}$ under formation of $\mathbf{2}$. The ${ }^{1} \mathrm{H}$ NMR spectrum of $\mathbf{2}$ exhibits two different resonances $(\delta 0.47$ and $0.32 \mathrm{ppm})$ for the $\mathrm{SiMe}_{3}$ groups and a singlet for the $\mathrm{NMe}_{2}$ substituent at $\delta 1.59 \mathrm{ppm}$. The ${ }^{13} \mathrm{C}$ NMR spectrum of 2 shows an upfield-shifted carbonyl resonance of the inserted ketone which appears at $\delta 94.8 \mathrm{ppm}$ in comparison to the starting material $(\delta$ 
$193.7 \mathrm{ppm})$ and three resonances $(\delta 38.68,3.15,3.06 \mathrm{ppm})$, which can be assigned to the carbon resonances arising from $\mathrm{NMe}_{2}$ and two $\mathrm{SiMe}_{3}$ groups, respectively. The ${ }^{29} \mathrm{Si} \mathrm{NMR}$ spectrum of 2 exhibits the $\mathrm{SiMe}_{3}$ to resonate at $\delta 0.034$ and -0.81 ppm with upfield-shifted signals compared to those of $\mathbf{1}$.

\section{Scheme 10}

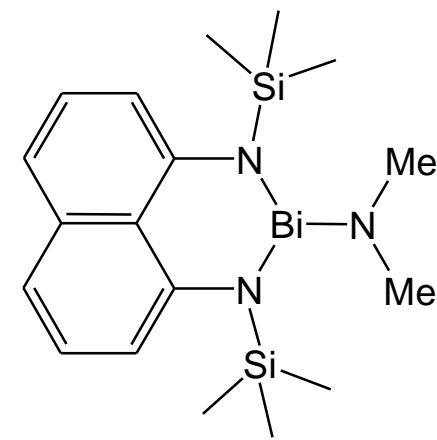

1

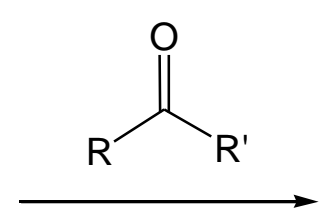

$n$-hexane

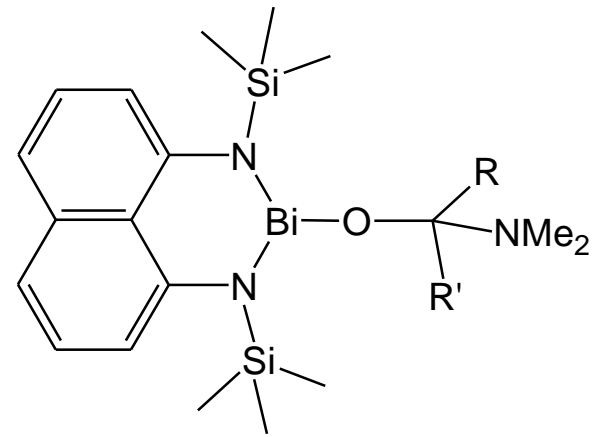

2: $\mathrm{R}=\mathrm{Ph}, \mathrm{R}^{\prime}=\mathrm{Py}-2$

$$
\text { 3: } \mathrm{R}=\mathrm{Py}-3 \mathrm{R}^{\prime}=\mathrm{H}
$$

Crystals of 2 suitable for an X-ray diffraction study were grown from $n$-hexane solution at $-30{ }^{\circ} \mathrm{C} . \quad 2$ is monomeric in the solid state and crystallizes in the triclinic space group $P \overline{1}$ (Figure 2). The coordination environment around the bismuth atom is distorted trigonal pyramidal with the bond angles in the range of $83.46(12)$ to $97.03(11)^{\circ}$ around the bismuth atom. The $\mathrm{Bi}-\mathrm{O}$ distance (2.089 (2) $\AA$ ) is in the range of a $\mathrm{Bi}-\mathrm{O}$ single bond when compared with other structural characterized bismuth compounds. ${ }^{92}$ The Bi-N4 (donor side-arm) distance of 2.615(4) $\AA$ is considerably longer than the $\mathrm{Bi}-\mathrm{N}$ bond lengths of the ligand (2.194(3) and 2.123(3) ̊). 


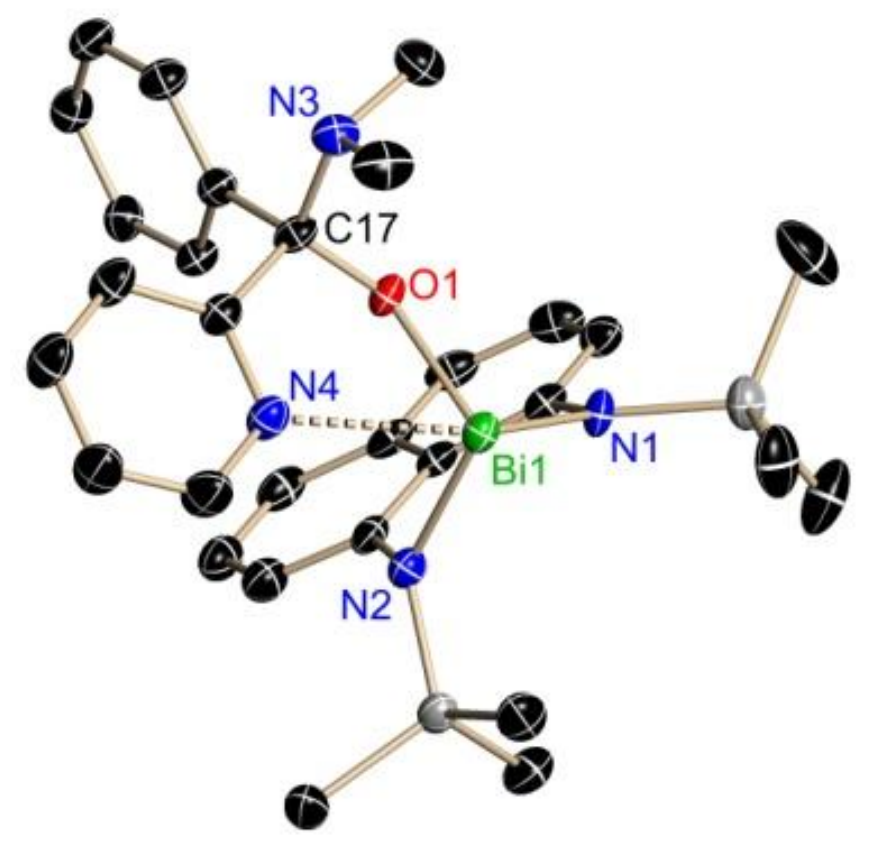

Figure 2. Crystal structure of 2, anisotropic displacement parameters depicted at the 50\% probability level. Hydrogen atoms are omitted for clarity. Selected bond lengths $[\AA]$ and angles [ํ]: Bi1-O1 2.089(2), Bi1-N1 2.194(3), Bi1-N2 2.123(3), Bi1-N4 2.615(4), O1-C17 1.405(4), O1-Bi1-N1 85.44(11), O1-Bi1-N2 97.03(11), N1-Bi1-N2 83.46 (12), Bi1-O1-C17 125.4(2).

In a similar manner a n-hexane solution of 1 smoothly reacts with 3pyridinecarboxaldehyde at room temperature to afford crystalline $\mathbf{3}$ in $75 \%$ yield (Scheme 10). The characterization of $\mathbf{3}$ indicates that the insertion of 3-pyridinecarboxaldehyde occurs selectively into the $\mathrm{Bi}-\mathrm{N}$ bond of $\mathbf{1}$. The ${ }^{1} \mathrm{H}$ NMR spectrum of $\mathbf{3}$ exhibits singlet resonances for the dimethylamine and quaternary $\mathrm{CH}$ protons, respectively ( $\delta 1.89$ and $5.05 \mathrm{ppm})$. The three methyl groups of the $\mathrm{SiMe}_{3}$ ligands appear at $\delta 0.3$ and $0.26 \mathrm{ppm}$. The ${ }^{13} \mathrm{C} \mathrm{NMR}$ spectrum of $\mathbf{3}$ shows a singlet resonance ( $\delta 89.23 \mathrm{ppm}$ ), which can be assigned to the carbonyl group of the inserted aldehyde, whereas the carbon atoms of $\mathrm{SiMe}_{3}$ and $\mathrm{NMe}_{2}$ groups resonate 
at $3.06,3.05$ and $39.35 \mathrm{ppm}$ respectively. 3 shows a resonance at 1.92 and $1.77 \mathrm{ppm}$ in its ${ }^{29} \mathrm{Si}$ NMR spectrum.

$\mathbf{3}$ crystallizes in the triclinic space group $P \overline{1}$ with two molecules in the asymmetric unit and the bismuth atom exhibits a trigonal pyramidal environment with bond angles of 83.96(8) to $91.85(9)^{\circ}$ (Figure 3 ). The $\mathrm{Bi}-\mathrm{O}$ distance in $3(2.10(2) \AA$ ) is in the range of $\mathrm{Bi}-\mathrm{O}$ single bonds when compared to literature examples $\left(2.058\right.$ and $2.109 \AA$ in $\left.\left[\mathrm{Bi}(\mathrm{ONp})_{3}(\mathrm{Py})_{2}\right]\right){ }^{92}$ In this structure also the $\mathrm{Bi}-\mathrm{N} 4$ (donor side-arm) distance of 2.891(4) $\AA$ is considerably longer than the $\mathrm{Bi}-\mathrm{N}$ bond lengths of the ligand (2.170(2) and 2.164(2) $\AA$ ).

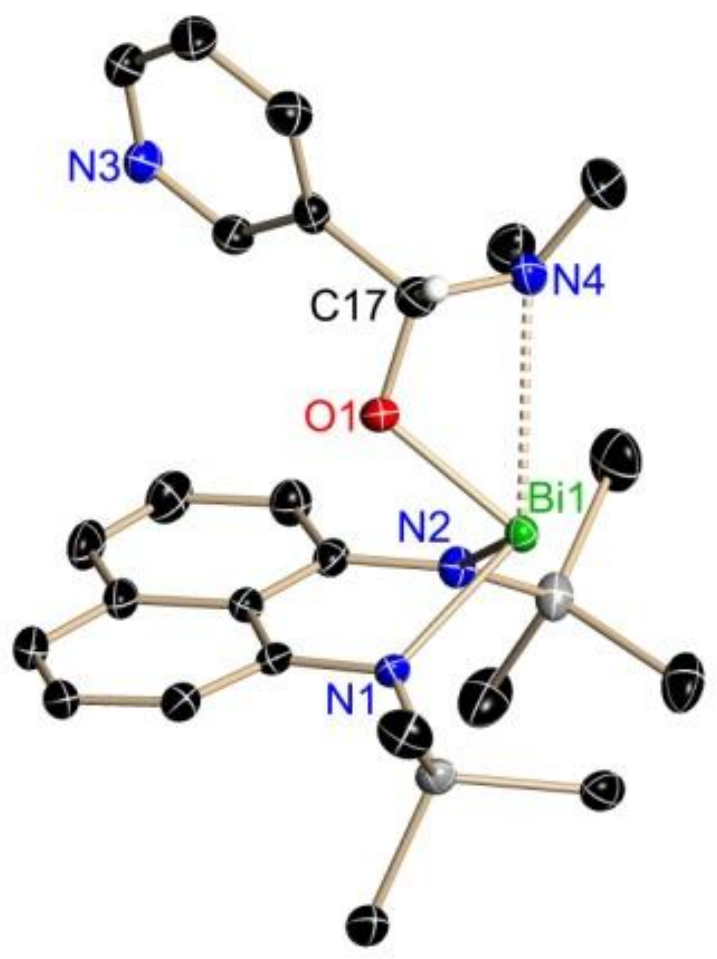

Figure 3. Crystal structure of 3, anisotropic displacement parameters depicted at the $50 \%$ probability level. Hydrogen atoms (except for those of C17) and disorder in one $\mathrm{SiMe}_{3}$ group are omitted for clarity. Selected bond lengths $[\AA]$ and angles $\left[^{\circ}\right]$ : Bi1-O1 2.10(2), Bi1-N1 2.170(2), Bi1-N2 2.164(2), Bi-N4 2.891(4), O1-C17 1.388(4), O1-Bi1-N1 83.96(11), O1-Bi1N2 91.85(9), N1-Bi1-N2 84.02 (9), Bi1-O1-C17 113.70(18) 


\subsubsection{Reaction of $\mathrm{L}^{1} \mathrm{BiNMe}_{2}$ (1) with Alkene and Alkine: Synthesis of} $\mathrm{L}^{1} \mathrm{BiC}(\mathrm{Me})(\mathrm{CN}) \mathrm{CH}_{2} \mathrm{NMe}_{2}(4)$ and $\mathrm{L}^{1} \mathrm{BiC}\left(\mathrm{CO}_{2} \mathrm{Et}\right) \mathrm{CNMe}_{2}\left(\mathrm{CONMe}_{2}\right)(5)$

The driving force for the formation of compounds $\mathbf{2}$ and $\mathbf{3}$ is the $\mathrm{Bi}-\mathrm{O}$ bond energy. For monomeric $\mathrm{BiO}$ it was determined by mass spectrometric measurement $\left(338.9 \pm 5.9 \mathrm{KJmol}^{-}\right.$ $\left.{ }^{1}\right){ }^{93}$ This value may well differ from a single Bi-O bond energy in the solid. Additionally the intramolecular coordination between bismuth and nitrogen (see Figures 2 and 3) may play an important role for the stability of these compounds. To extend those findings to bismuthcarbon bonds, we reacted $\mathbf{1}$ with an alkene and alkine, respectively, although aware that the $\mathrm{Bi}-\mathrm{C}$ bond is considerably weaker $\left(143 \mathrm{KJmol}^{-1}\right)^{94}$ than the $\mathrm{Bi}-\mathrm{O}$ bond. The reaction of $\mathbf{1}$ and 2-methyl-2-propenenitrile in $n$-hexane at $25^{\circ} \mathrm{C}$ gives the yellow complex 4 in $74 \%$ yield (Scheme 11). Formation of $\mathbf{4}$ proceeds with good yield and no decomposition products are observed. The ${ }^{1} \mathrm{H}$ NMR spectrum of 4 contains two none equivalent $\mathrm{CH}$ protons of the methylene residue ( $\delta 2.43$ and $4.53 \mathrm{ppm})$ and two singlets for $\mathrm{NMe}_{2}$ and $\mathrm{Me}(\delta 2.08$ and 1.17 ppm). The ${ }^{13} \mathrm{C}$ NMR spectrum indicates the presence of a new resonance ( $\left.\delta 62.6 \mathrm{ppm}\right)$, which can be assigned to the carbon atom that binds to the bismuth atom. 4 shows a resonance at $\delta$ 5.41 and $3.46 \mathrm{ppm}$ in its ${ }^{29} \mathrm{Si}$ NMR spectrum.

\section{Scheme 11}

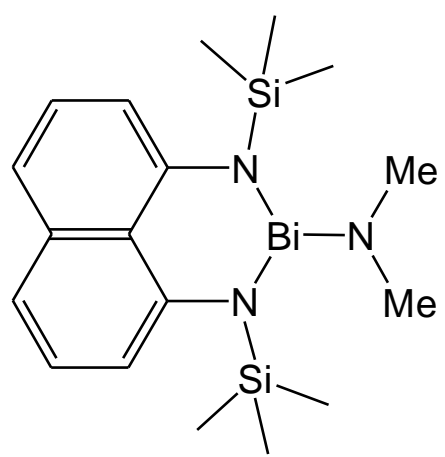

1

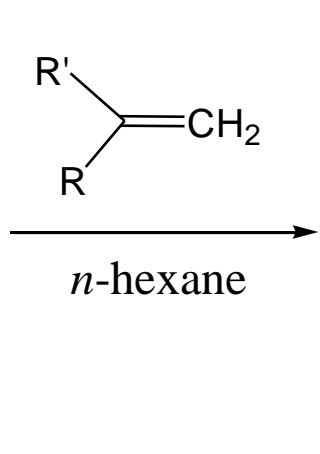

$$
\text { 4: } \mathrm{R}=\mathrm{Me}, \mathrm{R}^{\prime}=\mathrm{CN}
$$


Like the other structures, 4 is monomeric in the solid state and crystallizes in the monoclinic space group $P 2_{1} / c$ and in this structure again the bismuth atom shows the anticipated trigonal pyramidal coordination geometry with the bond angles in the range of $84.95(12)$ to $100.15(12)^{\circ}$ around the bismuth atom. Moreover, the crystal structure of 4 reveals that the bismuth atom and the $\mathrm{NMe}_{2}$ group are arranged at the same side of the molecule. This might be caused by the packing of the molecules in the crystal. The C17-C20 bond length of 1.540(5) $\AA$ is in the range of normal C-C single bonds (Figure 4). The Bi1C17 bond length $(2.341(3) \AA)$ in 4 is longer than those in $\left[t \mathrm{BuN}\left(\mathrm{CH}_{2} \mathrm{C}_{6} \mathrm{H}_{4}\right)_{2} \mathrm{BiMe}\right](2.264(6)$ $\AA$ ), ${ }^{95}$ whereas the Bi-N bond lengths (Bi1-N1 2.171(3), Bi1-N2 2.155(3) Å) are comparable to those observed in $\mathbf{1}$. In this structure also the Bi-N4 (donor side-arm) distance of 2.936(6) $\AA$ is considerably longer than the $\mathrm{Bi}-\mathrm{N}$ bond lengths of $\mathbf{1}$.

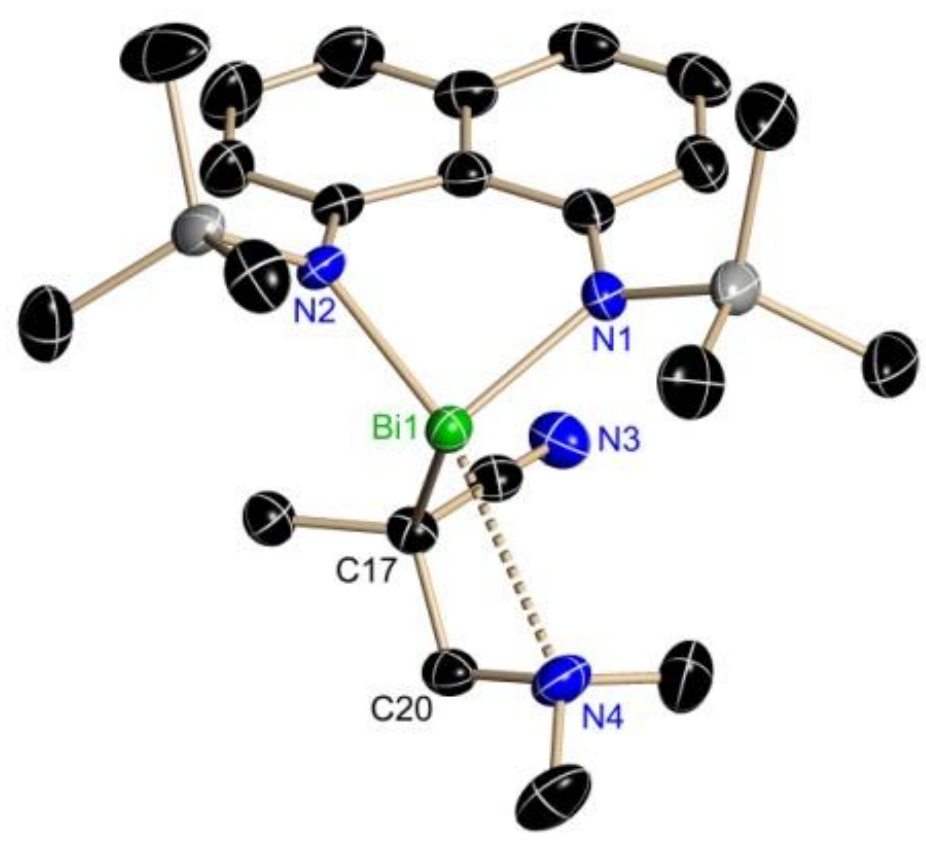

Figure 4. Crystal structure of 4, anisotropic displacement parameters depicted at the $50 \%$ probability level. Hydrogen atoms are omitted for clarity. Selected bond lengths $[\AA]$ and angles [ ${ }^{\circ}$ ]: Bi1-N1 2.171(3), Bi1-N2 2.155(3), Bi1-N4 2.936(6) Bi1-C17 2.341(3), N4-C20 
1.462(5), C17-C20 1.540(5), N1-Bi1-C17 100.15(12), N2-Bi1-C17 94.37(12), N1-Bi1-N2 84.95(12), C20-C17-Bi1 100.5(2), N4-C20-C17 112.8(3).

The reaction of 1 with diethyl acetylene dicarboxylate at $25^{\circ} \mathrm{C}$ in a molar ratio of $2: 1$ resulted in the yellow product 5 in $55 \%$ yield (Scheme 12). During the formation of 5 the exchange of one of the OEt groups by a $\mathrm{NMe}_{2}$ substituent occurred. The ${ }^{1} \mathrm{H}$ NMR spectrum of 5 displays three resonances as a singlet ( $\delta 2.43,0.52$ and $0.53 \mathrm{ppm})$ which can be attributed to the Me protons of $\mathrm{NMe}_{2}$ and $\mathrm{SiMe}_{3}$ groups, whereas non equivalent Me protons of the substituent $\mathrm{NMe}_{2}$ resonate as a singlet at $\delta 2.42$ and $1.20 \mathrm{ppm}$. The ${ }^{13} \mathrm{C}$ NMR spectrum of 5 reveals three resonances $(\delta 40.95,3.31$ and $3.206 \mathrm{ppm})$, which can be assigned to the carbon resonances arising from inserted $\mathrm{NMe}_{2}$ and $\mathrm{SiMe}_{3}$ groups, respectively, whereas the carbon atoms of the resulting $\mathrm{C}=\mathrm{C}$ double bond in $\mathbf{5}$ resonate at $\delta 169.3$ and 174.4 ppm. 5 shows a resonance at $\delta 2.154$ and $1.951 \mathrm{ppm}$ in its ${ }^{29} \mathrm{Si}$ NMR spectrum.

\section{Scheme 12}

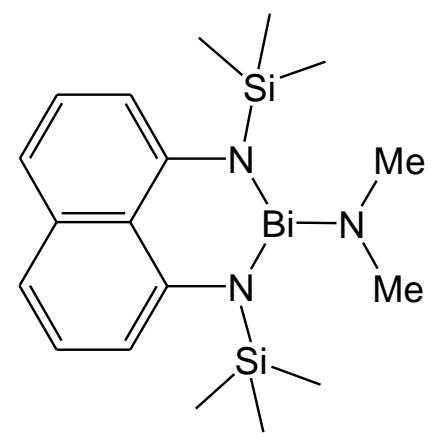

1
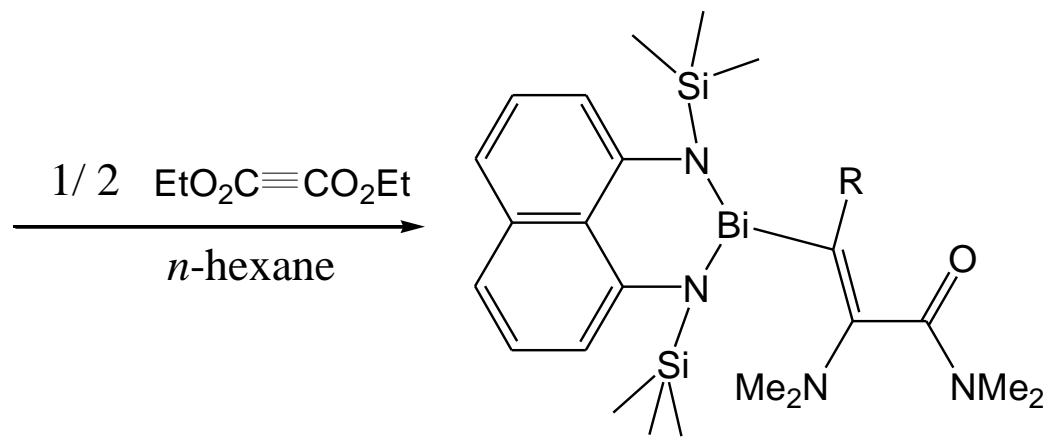

5: $\mathrm{R}=\mathrm{CO}_{2} \mathrm{Et}$

The crystal structure of $\mathbf{5}$ is shown in Figure 5. $\mathbf{5}$ is monomeric in the solid state and crystallizes in the triclinic space group $P_{\overline{1}}^{\overline{1}}$ with a trigonal pyramidal geometry at the bismuth atom. The structure reveals that the addition resulted in a Z-orientation of bismuth and the amide relative to the double bond. The $\mathrm{Bi}-\mathrm{O} 1\left(\mathrm{O}_{\text {carbonyl }}\right.$ donor $)$ distance $(2.70(40) \AA)$ is 
comparable with the $\mathrm{Bi}-\mathrm{O}_{\text {carbonyl }}$ interaction that ranges from 2.56 to $2.86 \AA$ in other known structures. $^{96}$ The Bi1-C18 bond length $(2.29(8) \AA)$ in $\mathbf{5}$ is comparable to those in $\left[t \mathrm{BuN}\left(\mathrm{CH}_{2} \mathrm{C}_{6} \mathrm{H}_{4}\right)_{2} \mathrm{BiCCPh}\right](2.289(4) \AA)^{95}$ but shorter than in $4(2.341(3) \AA)$.

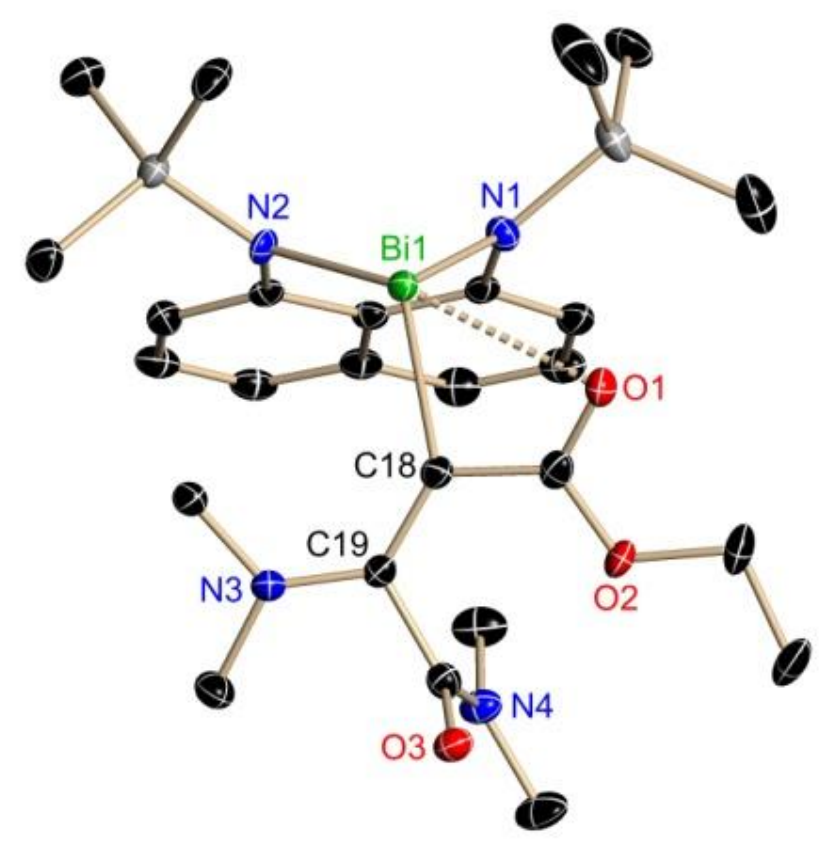

Figure 5. Crystal structure of $\mathbf{5}$, anisotropic displacement parameters depicted at the 50\% probability level. Hydrogen atoms are omitted for clarity. Selected bond lengths $[\AA]$ and angles [ ${ }^{\circ}$ ]: Bi1-N1 2.178(3), Bi1-N2 2.20(30), Bi1-O1 2.70(40), Bi1-C18 2.29(8), C18-C19 1.381(5), N1-Bi1-C18 92.2(5), N2-Bi1-C18 103(6), N1-Bi1-N2 81.64(16).

2.1.4. Reaction of $\mathrm{L}^{1} \mathrm{BiNMe}_{2}$ (1) with $\mathrm{N}, \mathrm{N}^{\prime}$-diisopropylcarbodiimide: Synthesis of 1,8$\mathrm{C}_{10} \mathrm{H}_{6}\left(\mathrm{NSiMe}_{3}\right)_{2} \mathrm{Bi}(\mathrm{NiPr})_{2} \mathrm{CNMe}_{2}(6)$

Compounds 2-5 show reactivity of bismuth-nitrogen bond toward carbon-carbon and carbon-oxygen bonds. To extend those findings to carbon-nitrogen bonds, we reacted $\mathbf{1}$ with diisopropylcarbodiimide and phenylisocyanate, respectively.

Reaction of diisopropylcarbodiimide with $\mathbf{1}$ in $n$-hexane results in the formation of $\mathbf{6}$, indicating that one carbodiimide molecule is inserted into the Bi-N bond (Scheme 13). 
Compounds $\mathbf{6}$ is an orange crystalline solid, which is soluble in organic solvents such as $n$-hexane, THF, and toluene. The ${ }^{1} \mathrm{H}$ and ${ }^{13} \mathrm{C}$ NMR spectra also confirm the insertion of diisopropylcarbodiimide into the $\mathrm{Bi}-\mathrm{N}$ bond of $\mathbf{1}$ under formation of $\mathbf{6}$. The ${ }^{1} \mathrm{H}$ NMR spectrum of 6 displays two resonances ( $\delta 1.99,0.34 \mathrm{ppm})$ which can be attributed to the $\mathrm{NMe}_{2}$ and $\mathrm{SiMe}_{3}$ groups, respectively, whereas the two and twelve protons of $\mathrm{N}$-isopropyl groups resonate at $\delta 3.93$ and $0.94 \mathrm{ppm}$. The ${ }^{13} \mathrm{C}$ NMR spectrum of 6 shows upfield-shifted resonances of $\mathrm{NMe}_{2}(\delta 39.7 \mathrm{ppm})$, in comparison to $\mathbf{1}(\delta 41.9 \mathrm{ppm})$, whereas the carbon atoms of the $\mathrm{N}$-isopropyl and $\mathrm{SiMe}_{3}$ groups resonate at $\delta 39.7,24.9$, and $2.7 \mathrm{ppm}$, respectively. The ${ }^{29} \mathrm{Si}$ NMR spectrum of 6 exhibits a singlet resonance $(\delta 0.21 \mathrm{ppm})$ which can be assigned to $\mathrm{SiMe}_{3}$ groups.

\section{Scheme 13}

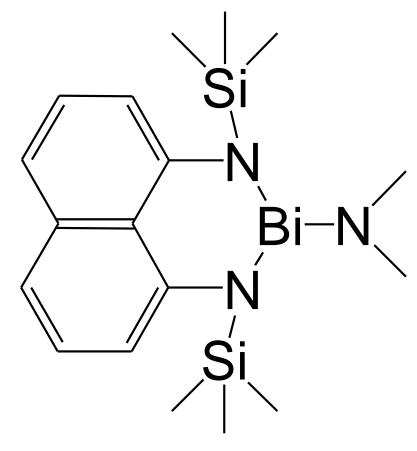

1

\section{$i \mathrm{PrN}=\mathrm{C}=\mathrm{N} i \mathrm{Pr}$} n-hexane

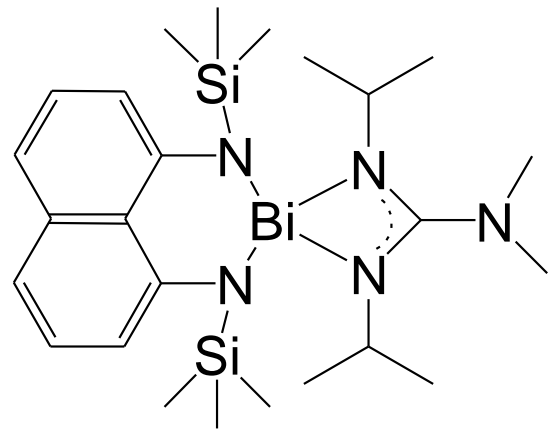

6

Single crystals of $\mathbf{6}$, suitable for X-ray diffraction studies, were obtained from a saturated solution of $n$-hexane at $-30{ }^{\circ} \mathrm{C}$. In 6 the bismuth atom is tetracoordinate in an irregular tetragonal-pyramidal geometry. Compound 6 crystallizes in the monoclinic space group $P 2_{1} / n$ with one molecule in the asymmetric unit (Figure 6). The bismuth center in $\mathbf{6}$ is coordinate to two nitrogen atoms of the anionic ligand and to two nitrogen atoms of carbodiimide unit. The $\mathrm{C}-\mathrm{N}$ bond distances associated with the central $\mathrm{sp}^{2}$ carbon of the carbodiimide species are almost equal and are considerably shorter than a typical C-N single bond, suggesting that the 
three C-N bonds possess a partial double-bond character with typical $\mathrm{C}(17)-\mathrm{N}(3), \mathrm{C}(17)-$ $\mathrm{N}(4)$, and C(17)-N(5) distances of 1.380(2), 1.309(2), and 1.369(2) A respectively.

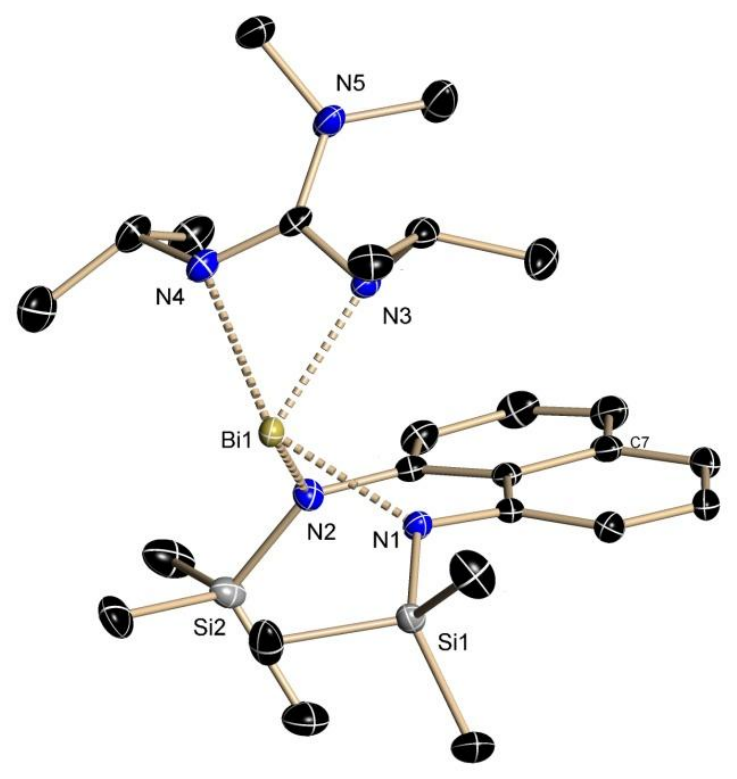

Figure 6. Molecular structure of 6. Thermal ellipsoids are set at 50\% probability level. $\mathrm{H}$ atoms are omitted for clarity. Selected bond lengths $[\AA]$ and angles $\left[^{\circ}\right]$ : $\operatorname{Bi}(1)-\mathrm{N}(1) 2.2356(13)$, Bi1-N2 2.1418(14), Bi1-N3 2.2035(14), Bi1-N4 2.5259(14), N1-Si1 1.7316(14), N2-Si2 1.7319(14), C17-N3 1.380(2), C17-N4 1.309(2), C17-N5 1.369(2), N1-Bi1-N2 81.51, N2Bi1-N3 96.87(5), N3-Bi1-N4 56.83(5), N1-Bi1-N3 91.34(5), N1-Bi1-N4 144.97(5), N2-Bi1N4 87.78(5).

\subsubsection{Reaction of $\mathrm{L}^{1} \mathrm{BiNMe}_{2}$ (1) with Phenylisocyanate: Synthesis of 1,8- $\mathrm{C}_{10} \mathrm{H}_{6}\left(\mathrm{NSiMe}_{3}\right)_{2} \mathrm{BiNPhCONMe}_{2}(7)$}

In a similar manner to $\mathbf{6}, n$-hexane solution of $\mathbf{1}$ smoothly reacts with phenylisocyanate at room temperature to afford crystalline 7 in $69 \%$ yield under isocyanate insertion into the Bi-N bond of 1 (Scheme 14). The ${ }^{1} \mathrm{H}$ NMR spectrum of 7 in $\mathrm{C}_{6} \mathrm{D}_{6}$ exhibits two singlets $(\delta 2.08$, $0.31 \mathrm{ppm}$ ) for $\mathrm{NMe}_{2}$ and $\mathrm{SiMe}_{3}$ groups. The ${ }^{13} \mathrm{C}$ NMR spectrum of 7 shows an upfield-shifted resonance of $\mathrm{NMe}_{2}(\delta 37.5 \mathrm{ppm})$ in comparison to $\mathbf{1}(\delta 41.9 \mathrm{ppm})$, confirming the insertion of 
phenylisocyanate into the $\mathrm{Bi}-\mathrm{N}$ bond of $\mathbf{1}$, whereas the carbon atoms of $\mathrm{SiMe}_{3}$ resonate as a singlet at $\delta 2.71 \mathrm{ppm}$. The ${ }^{29} \mathrm{Si}$ NMR spectrum of 6 displays one resonance at $\delta 2.93 \mathrm{ppm}$ which can be attributed to the $\mathrm{SiMe}_{3}$ groups.

\section{Scheme 14}

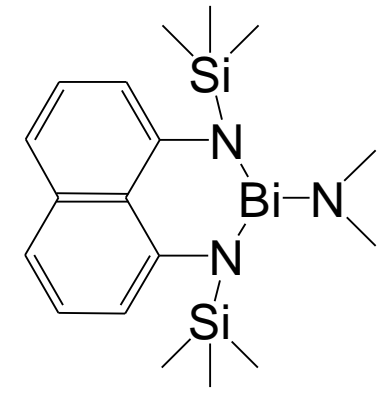

1

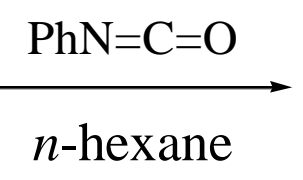

n-hexane

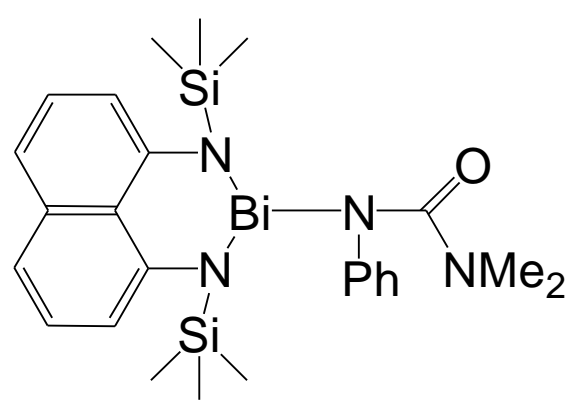

7

Yellow crystals of $\mathbf{7}$, suitable for single-crystal X-ray diffraction study, were obtained from a saturated solution of $n$-hexane at $-30{ }^{\circ} \mathrm{C}$. The coordination geometry around the bismuth atom in $\mathbf{7}$ is a distorted pyramidal arrangement with a stereochemically active electron lone pair. Compound 7 crystallizes in the triclinic space group $P \overline{1}$ with two molecules in the asymmetric unit (Figure 6). In 7 the $\mathrm{N}-\mathrm{C}$ (av 1.384 $\AA$ ) and $\mathrm{C}-\mathrm{O}$ (av $1.255 \AA$ ) bond distances of the ureato fragments are both in the range of single and double bonds, indicating that the $\pi$ electrons of the ureato fragments are partially delocalized in the $\mathrm{NC}(\mathrm{N}) \mathrm{O}$ core. Additionally, the intramolecular coordination between bismuth and oxygen may play an important role for the stability of this compound. 


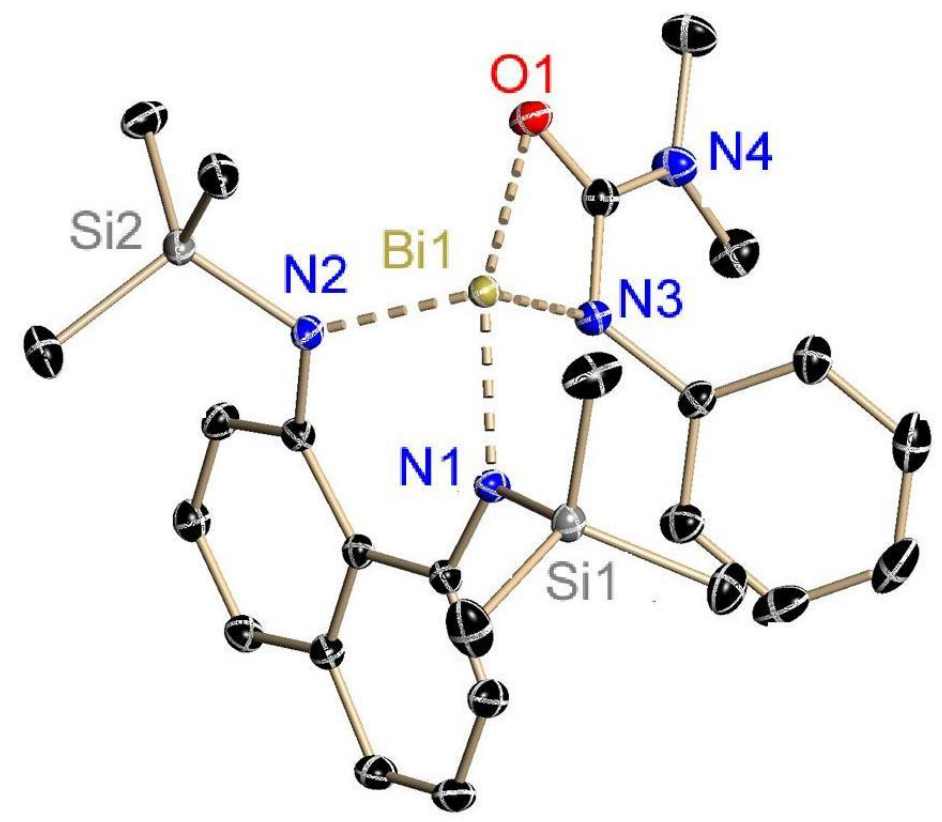

Figure 7. Molecular structure of 7. Thermal ellipsoids are set at 50\% probability level. Only one of the two crystallographically independent molecules is shown. $\mathrm{H}$ atoms are omitted for clarity. Selected bond lengths $[\AA]$ and angles $\left[^{\circ}\right]$ : Bi1-N 2.157914, Bi1-N2 2.1183(14), Bi1N3 2.2334(15), N1-Si1 1.7371(15), N2-Si2 1.7297(15), Bi1-O1 2.6364(13), C17-N3 1.373(2), C17-N4 1.351(2), C17-O1 1.266(2), N1-Bi1-N2 85.40(6), N1-Bi1-N3 92.88(5), N2Bi1-N3 97.08(6), C17-N3-Bi1 101.30(11), N1-Bi1-O1 146.87(5), N2-Bi1-O1 93.36(5)

\subsection{Heterobimetallic Bismuth Complexes with Main Group and Transition Metals}

Since the first isolation and characterization of a bismuth-transition metal heterobimetallic alkoxide in $1996,{ }^{97}$ a wide variety of bismuth heterobimetallic complexes have been synthesized and reviewed. ${ }^{98}$ Limberg and coworkers reported the first structurally characterized molecular complexes with Bi-O-Mo linkages. These moieties are thought to be the active oxo-transfer sites during allylic oxidation of propene. ${ }^{99}$ The solid state structure of the first coordination complex containing bismuth and aluminum has also been described. ${ }^{100}$ We have recently reported the synthesis and structural characterization of $\mu$-oxo bridged Al$\mathrm{O}-\mathrm{M}(\mathrm{M}=\mathrm{Zr}, \mathrm{Ti}, \mathrm{Hf}), \mathrm{M}-\mathrm{O}-\mathrm{M}^{1}\left(\mathrm{M}=\mathrm{Ti}, \mathrm{Zr} ; \mathrm{M}^{1}=\mathrm{Al}, \mathrm{Ga}\right), \mathrm{Ge}-\mathrm{O}-\mathrm{M}(\mathrm{M}=\mathrm{Zr}, \mathrm{Hf})$, and Al-O-M- 
$\mathrm{O}-\mathrm{Al}(\mathrm{M}=\mathrm{Ti}, \mathrm{Zr})$ complexes. ${ }^{101}$ Herein we report a general synthetic approach and structural characterization of five bismuth heterobimetallic complexes with main group and transition metals.

\subsubsection{Reaction of $\mathrm{L}^{1} \mathrm{BiNMe}_{2}(1)$ with $\mathrm{LM}(\mathrm{Me})(\mathrm{OH})$ : Synthesis of $1,8 \mathrm{C}_{10} \mathrm{H}_{6}\left(\mathrm{NSiMe}_{3}\right)_{2} \mathrm{Bi}(\mu-$ O)MMeL $(M=A l 8 ; G a, 9)$}

Treatment of 1 with stoichiometric amounts of $\mathrm{LM}(\mathrm{Me})(\mathrm{OH})(\mathrm{M}=\mathrm{Al}, \mathrm{Ga})$ in $n$-hexane at room temperature results in the formation of $\mathbf{8}$ and $\mathbf{9}$ exhibiting the Bi-O-M (M=Al 8, Ga 9) moiety (Scheme 15). Compounds $\mathbf{8}$ and $\mathbf{9}$ are soluble in toluene, THF, and $n$-hexane and are characterized by analytical, spectroscopic, and single-crystal X-ray diffraction studies. Compounds 8 and 9 are yellow crystalline solids that melt at $174{ }^{\circ} \mathrm{C}$ and $191{ }^{\circ} \mathrm{C}$. The ${ }^{1} \mathrm{H}$ NMR spectra of the reaction mixture of compounds 8-9 show almost quantitative conversion of the reactants to products, as revealed by the absence of any $\mathrm{M}-\mathrm{OH}$ and $\mathrm{NMe}_{2}$ resonances. The ${ }^{1} \mathrm{H}$ NMR spectrum of $\mathbf{8}$ displays two resonances ( $\delta-0.69$ and $0.24 \mathrm{ppm})$ which can be attributed to the Me protons of AlMe and $\mathrm{SiMe}_{3}$ groups, respectively, whereas the particular GaMe and $\mathrm{SiMe}_{3}$ groups in compound 9 resonate at $\delta-0.56$ and $0.28 \mathrm{ppm}$. In addition, a set of resonances assignable to the isopropyl and methyl protons associated with the $\beta$-diketiminate ligand is found in the range between $\delta 1.31$ and $0.99 \mathrm{ppm}$, and the absence of the $\mathrm{OH}$ proton resonance features both 8 and 9. The mass spectral data of compounds 8-9 are in agreement with the assigned structures. Compound $\mathbf{8}$ is moderately air and moisture sensitive, but thermally quite stable as indicated by the high melting point and EI mass spectrum in which the molecular ion $\left(\mathrm{M}^{+}\right)$was observed with $100 \%$ intensity. The next most intense peak at $\mathrm{m} / \mathrm{z}$ 969.5 was assigned to $[\mathrm{M}-\mathrm{Me}]^{+}$. 


\section{Scheme 15}

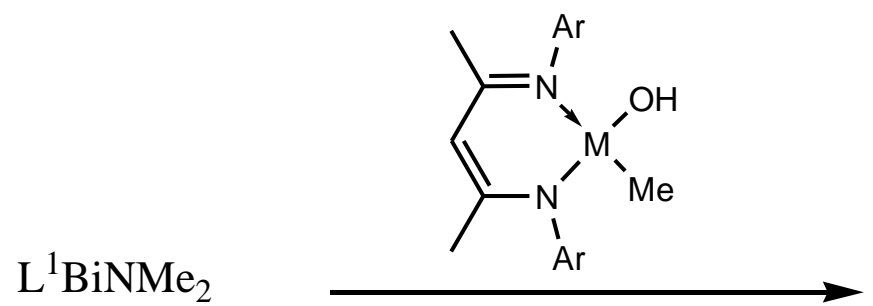

1

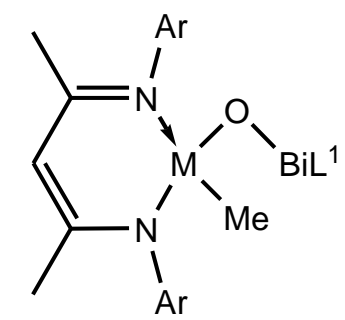

8: $\quad \mathrm{M}=\mathrm{Al}$

9: $\quad M=G a$

Yellow crystals of $\mathbf{8}$ suitable for single-crystal X-ray diffraction study were obtained from a saturated solution of $n$-hexane at $-30{ }^{\circ} \mathrm{C}$ and for those of 9 from a mixture of $n$ hexane/toluene solution at $-30{ }^{\circ} \mathrm{C}$. Compounds $\mathbf{7}$ and $\mathbf{8}$ crystallize in the monoclinic space group $P 2_{1} / c$, with two and one molecules in the asymmetric unit, respectively (Figures 8,9 ). The aluminum and gallium atoms adopt each a distorted tetrahedral environment, whereas the coordination geometry around the bismuth atom is that of a distorted pyramidal arrangement with a stereochemically active electron lone pair. The Al-O distance (av $1.834 \AA$ ) is similar to that which has been reported for complex $\left[\left\{\mathrm{Bi}(\mathrm{Hsal})_{3}\right\}_{2}\left\{\mathrm{Al}(\mathrm{acac})_{3}\right\}\right](\mathrm{av} 1.871 \AA) .{ }^{100}$ The $\mathrm{Al}(\mu-\mathrm{O}) \mathrm{Bi}$ angle (av $\left.160.6^{\circ}\right)$ in 2 is considerably bigger than the corresponding $\mathrm{Al}(\mu-\mathrm{O}) \mathrm{Ga}$ bond angle in $\mathbf{3}\left(123.25(7)^{\mathrm{o}}\right)$. 


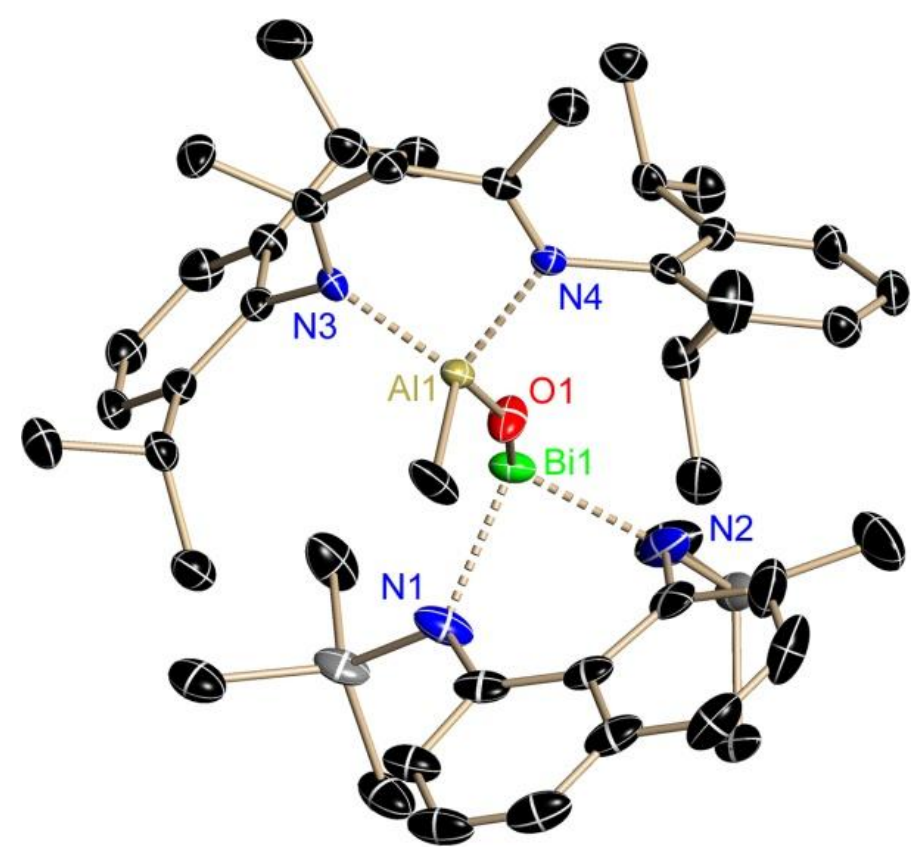

Figure 8. Molecular structure of 8. Only one of the two independent molecules in the crystal is shown. Anisotropic displacement parameters are depicted at the 50\% probability level. $\mathrm{H}$ atoms and disordered $\mathrm{SiMe}_{3}$-groups are omitted for clarity. Selected bond lengths $[\AA]$ and angles [ํ]: Bi1-O1 1.995(4), Bi1-N2 2.115(4), Bi1-N1 2.157(4), Al1-O1 1.690(3), Al1-N3 1.902(4), Al1-N4 1.931(4), Al1-C46 1.959(5), O1-Bi1-N2 92.55(16), O1-Bi1-N1 95.16(16), N2-Bi1-N1 85.5417, O1-Al1-N3 111.13(18), O1-Al1-N4 111.14(18), N3-Al1-N4 95.97(16), O1-Al1-C46 116.2(2), N3-Al1-C46 111.8(2), N4-Al1-C46 108.8(2), Al1-O1-Bi1 160.7(2)

The Ga-N bond lengths (1.963(16) and 1.973(16) $\AA$ ) and the N-Ga-N angle $\left(95.87(6)^{\circ}\right)$ are comparable to those observed in $\left[\mathrm{Me}_{2} \mathrm{Ga}\left(2-\mathrm{NC}_{5} \mathrm{H}_{4}\right)_{2} \mathrm{CH}\right] .{ }^{102}$ The angle for the bent Ga-OBi linkage is $123.25(7)^{\circ}$, which is considerably more acute than that in $\operatorname{LGa}(\mathrm{Me})(\mu$ $\mathrm{OH}) \mathrm{LnCp}_{3}\left(\mathrm{Ln}=\mathrm{Sm}, \mathrm{Nd}\right.$; av $\left.149.5^{\circ}\right)$. The corresponding Ga-O bond length $(1.815(13) \AA)$ is shorter than the $\mathrm{Ga}-\mu-\mathrm{OH}$ bond in $\mathrm{LGa}(\mathrm{Me})(\mu-\mathrm{OH}) \mathrm{LnCp}_{3}$ (av $\left.1.856 \AA\right) .{ }^{103}$ Obviously there is more charge accumulated at the $\mathrm{O}^{2-}$ in $\mathbf{3}$ than at the $\mathrm{OH}^{-}$in the latter complex. 


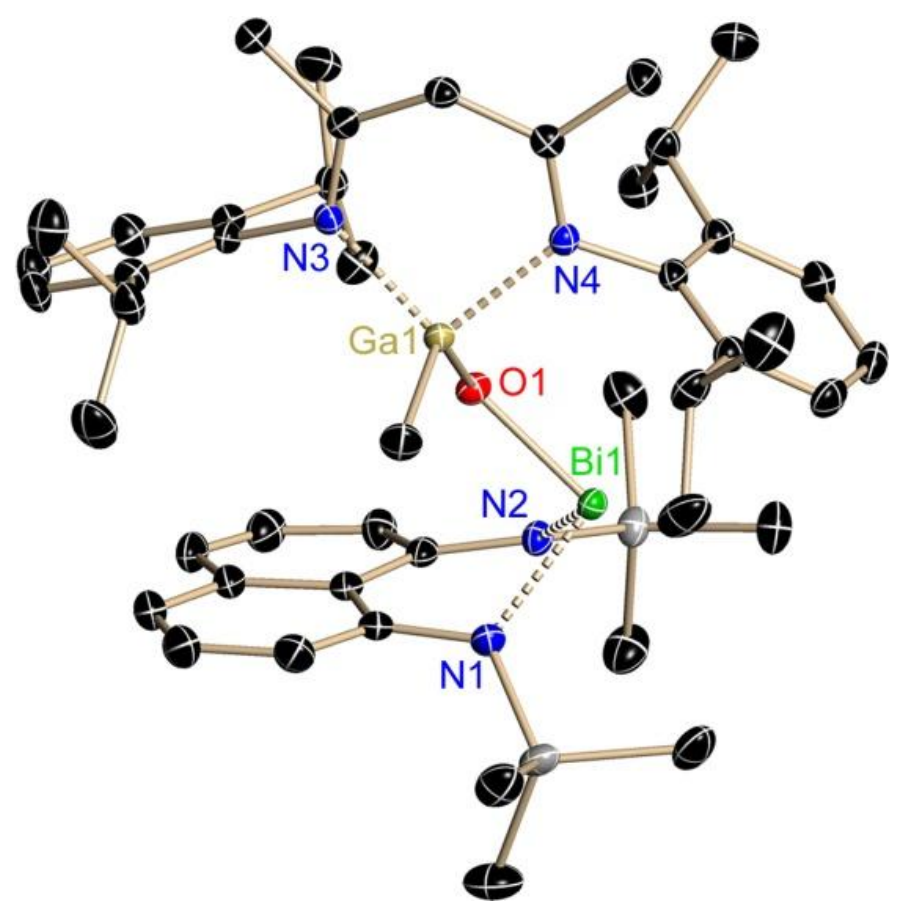

Figure 9. Molecular structure of 9. Anisotropic displacement parameters are depicted at the $50 \%$ probability level. $\mathrm{H}$ atoms and one toluene solvent molecule are omitted for clarity. Selected bond lengths $[\AA ̊ 0]$ and angles $\left[{ }^{\circ}\right]$ : Bi1-O1 2.0282(13), Ga1-O1 1.8159(13), Ga1-C100 1.955(2), Bi1-N1 2.1425(17), Bi1-N2 2.1443(16), O1-Ga1-N4 103.90(6), C100-Ga1-N3 111.54(8), C100-Ga1-N4 113.33(8), O1-Bi1-N1 93.67(6), N1-Bi1-N2 85.13(6), N3-Ga1-N(4) 95.87(6), Ga1-O1-Bi1 123.25(7), O1-Bi1-N2 94.02(6), O1-Ga1-N3 109.26(6), O1-Ga1-C100 120.06(8).

2.2.2. Reaction of $\mathrm{L}^{1} \mathrm{BiNMe}_{2}$ (1) with $\mathrm{LGe}(\mathrm{OH})$ : Synthesis of $1,8-\mathrm{C}_{10} \mathrm{H}_{6}\left(\mathrm{NSiMe}_{3}\right)_{2} \mathrm{Bi}(\mu-$ O)GeL (10)

Similarly the reaction of 1 with $\mathrm{LGe}(\mathrm{OH})$ in $n$-hexane at room temperature affords 1,8 $\mathrm{C}_{10} \mathrm{H}_{6}\left(\mathrm{NSiMe}_{3}\right)_{2} \mathrm{Bi}(\mu-\mathrm{O}) \mathrm{GeL}(\mathbf{1 0})$ in moderate yield (63\%) (Scheme 16). The ${ }^{1} \mathrm{H} \mathrm{NMR}$ and ${ }^{29} \mathrm{Si}$ NMR spectra of $\mathbf{1 0}$ exhibit singlets at $\delta 0.24$ and $0.99 \mathrm{ppm}$, respectively, corresponding to the $\mathrm{SiMe}_{3}$ groups. Complex $\mathbf{1 0}$ is a yellow crystalline solid which is soluble in common organic solvents such as toluene, THF, and $n$-hexane and is stable at room temperature for several months under an inert atmosphere. In the mass spectrum of $\mathbf{1 0}$ the peak with the 
highest mass corresponds to the molecular ion $\mathrm{M}^{+}$and the next most intense peak is observed at $m / z, 599$ which can be assigned to the fragment $\left[\mathrm{M}-\mathrm{CH}(\mathrm{DippNCMe})_{2}\right]^{+}$.

\section{Scheme 16}

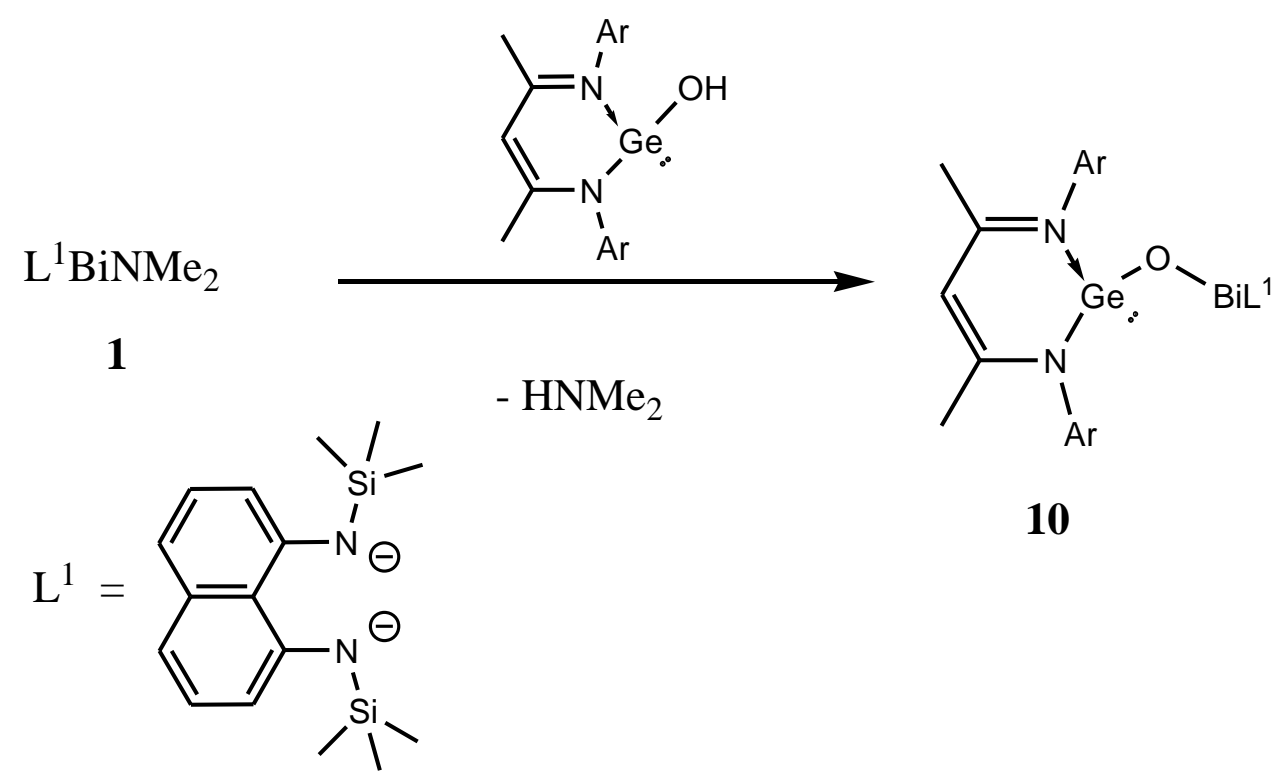

Compound $\mathbf{1 0}$ crystallizes in the monoclinic space group $P 2_{1} / n$ with two molecules and one disordered $n$-hexane in the asymmetric unit. As expected, 10 contains the bismuth atom bonded through an oxygen atom to germanium (Figure 10). The bismuth and germanium atoms both exhibit a highly distorted pyramidal geometry, involving the chelating 1,8$\mathrm{C}_{10} \mathrm{H}_{6}\left(\mathrm{NSiMe}_{3}\right)_{2}$ ligand and $\beta$-diketiminato ligand, the $(\mu$-O) atom and a stereochemically active lone pair at each atom. The Ge-N bond lengths (av 2.010 and $2.049 \AA$ ) and N-Ge-N angle (av $87.47^{\circ}$ ) are comparable to those of oxygen-bridged heterobimetallic complexes reported in reference 104. 10 features a bent Ge-O-Bi (av 118.89 $)$ arrangement with a Ge-O distance of av $1.825 \AA$ and a Bi-O bond length of av $2.052 \AA$. The Ge-O bond length is longer than those in Ge-O-Yb $(1.769 \AA)$ and Ge-O-Y (1.762 $\AA)$ species ${ }^{105}$ and is comparable

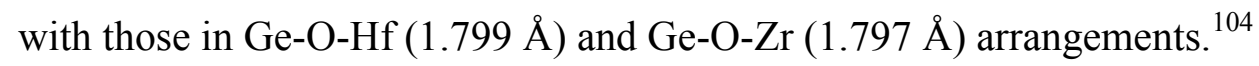




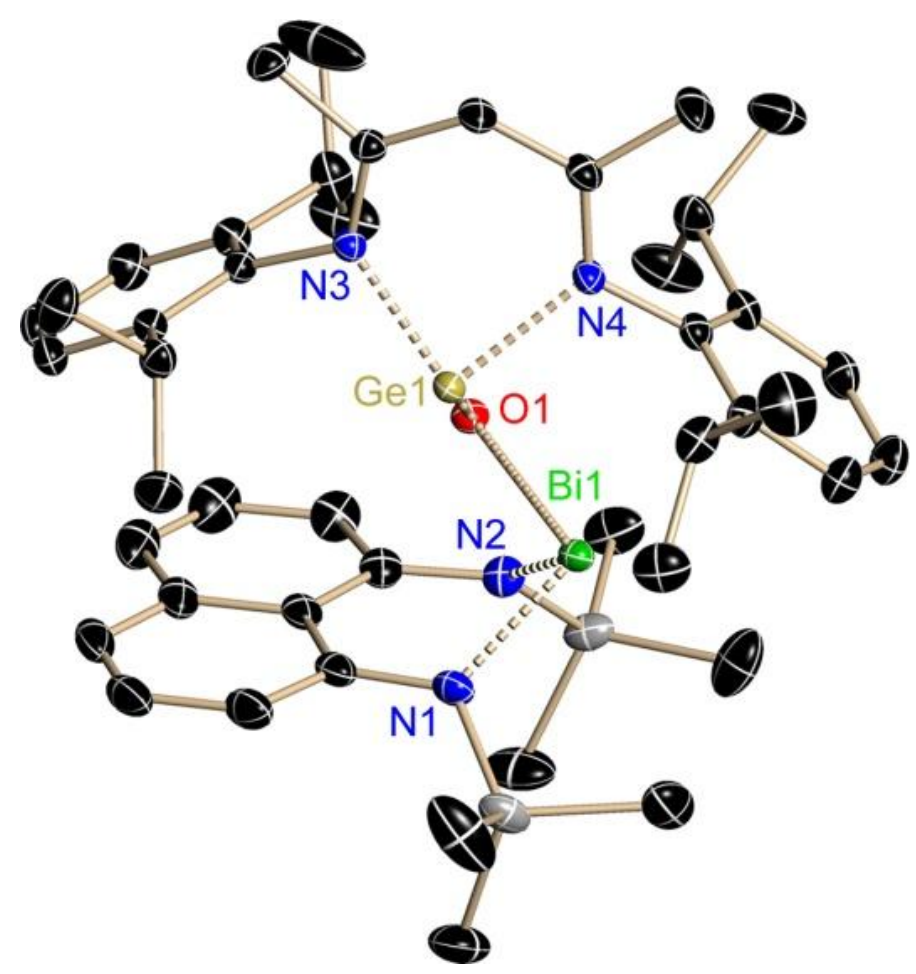

Figure 10. Molecular structure of 10. Only one of the two independent molecules in the crystal is shown. Anisotropic displacement parameters are depicted at the 50\% probability level. $\mathrm{H}$ atoms and half a molecule of $n$-hexane are omitted for clarity. Selected bond lengths

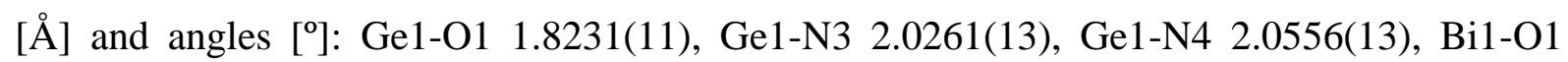
2.0493(11), Bi1-N1 2.1389(14), Bi1-N2 2.1614(14), Ge1-O1-Bi(1) 125.20(6), O1-Bi1-N1 96.72(5), O1-Bi1-N2 93.05(5), N1-Bi1-N2 84.77(5), O1-Ge1-N3 97.57(5), O1-Ge1-N4 92.28(5), N3-Ge1-N4 87.68(5).

2.2.3. Reaction of $\mathrm{L}^{1} \mathrm{BiNMe}_{2}(1)$ with $\mathrm{Cp}_{2}{ }_{2} \mathrm{MR}(\mathrm{OH})$ : Synthesis of $1,8-\mathrm{C}_{10} \mathrm{H}_{6}\left(\mathrm{NSiMe}_{3}\right)_{2} \mathrm{Bi}(\mu-$ $O) M R C p *_{2}(M=\operatorname{Zr} 11, R=M e ; H f, 12, R=C l)$

The synthesis of $1,8-\mathrm{C}_{10} \mathrm{H}_{6}\left(\mathrm{NSiMe}_{3}\right)_{2} \mathrm{Bi}(\mu-\mathrm{O}) \mathrm{ZrMeCp}_{2}{ }_{2}(\mathbf{1 1})$ and $1,8-\mathrm{C}_{10} \mathrm{H}_{6}\left(\mathrm{NSiMe}_{3}\right)_{2} \mathrm{Bi}-$ $(\mu-\mathrm{O}) \mathrm{HfClCp}_{2}{ }_{2}(\mathbf{1 2})$ are accomplished by reacting 1 with $\mathrm{Cp}^{*}{ }_{2} \mathrm{ZrMe}(\mathrm{OH})$ and the in situ reaction with $\mathrm{Cp}^{*}{ }_{2} \mathrm{HfCl}(\mathrm{OH})$, respectively (Scheme 17). $\mathrm{Cp}^{*}{ }_{2} \mathrm{HfCl}(\mathrm{OH})$ was prepared from $\mathrm{Cp}^{*}{ }_{2} \mathrm{HfCl}_{2}$ and water in the presence of a $\mathrm{N}$-heterocyclic carbene $\left[\mathrm{CN}(i \mathrm{Pr}) \mathrm{C}_{2} \mathrm{Me}_{2} \mathrm{~N}(i \mathrm{Pr})\right]$. The carbene is used for trapping quantitatively the generated $\mathrm{HCl}$ from hydrolysis of $\mathrm{Cp}^{*}{ }_{2} \mathrm{HfCl}_{2}$. 
Compounds $\mathbf{1 1}$ and $\mathbf{1 2}$ are yellow solids, which are thermally quite stable as evidenced by their high melting points $\left(206^{\circ} \mathrm{C}\right.$ and $210{ }^{\circ} \mathrm{C}$ respectively) and the presence of molecular ions in their EI mass spectra. 11 is soluble in toluene, THF, and $n$-hexane, while compound $\mathbf{1 2}$ is soluble in toluene and THF only. The ${ }^{1} \mathrm{H}$ and ${ }^{13} \mathrm{C}$ NMR data of $\mathbf{1 1}$ and $\mathbf{1 2}$ are consistent with the determined single crystal structures. The ${ }^{1} \mathrm{H}$ NMR spectrum of $\mathbf{1 1}$ in $\mathrm{C}_{6} \mathrm{D}_{6}$ exhibits three singlets $(\delta 0.28,1.63,-0.43 \mathrm{ppm})$ attributed to the proton resonances arising from $\mathrm{SiMe}_{3}, \eta^{5}-$ $\mathrm{C}_{5} \mathrm{Me}_{5}$, and $\mathrm{Zr}-\mathrm{Me}$ groups, whereas the respective $\mathrm{SiMe}_{3}$ and $\eta^{5}-\mathrm{C}_{5} \mathrm{Me}_{5}$ groups in compound 12 resonate at $\delta 0.3$ and $1.73 \mathrm{ppm}$. The ${ }^{13} \mathrm{C}$ NMR spectrum of 11 reveals two resonances $(\delta$ 25.7, $11.3 \mathrm{ppm}$ ), which can be assigned to the carbon resonances arising from $\mathrm{Zr}$-Me and $\mathrm{Zr}$ $\mathrm{Cp}^{*}$, respectively. In compound $\mathbf{1 2}$ the carbon atoms of the methyl groups (Hf-Cp*) resonate at $\delta 11.5 \mathrm{ppm}$. The mass spectrometry data for $\mathbf{1 1}$ revealing a signal of low intensity for the molecular ion and the base peak is observed at $\mathrm{m} / \mathrm{z} 494.1$ corresponding to [M-Cp* $\mathrm{Zr}(\mathrm{Me})-$ $\mathrm{OMe}^{+}$. In the mass spectrum of compound $\mathbf{1 2}$ the base peak is observed at $\mathrm{m} / \mathrm{z}, 875.3$ representing $\left[\mathrm{M}-\mathrm{Cp}^{*}\right]^{+}$and the peak with the highest mass corresponds to the molecular ion $\mathrm{M}^{+}(m / z, 1010.5)$.

\section{Scheme 17}
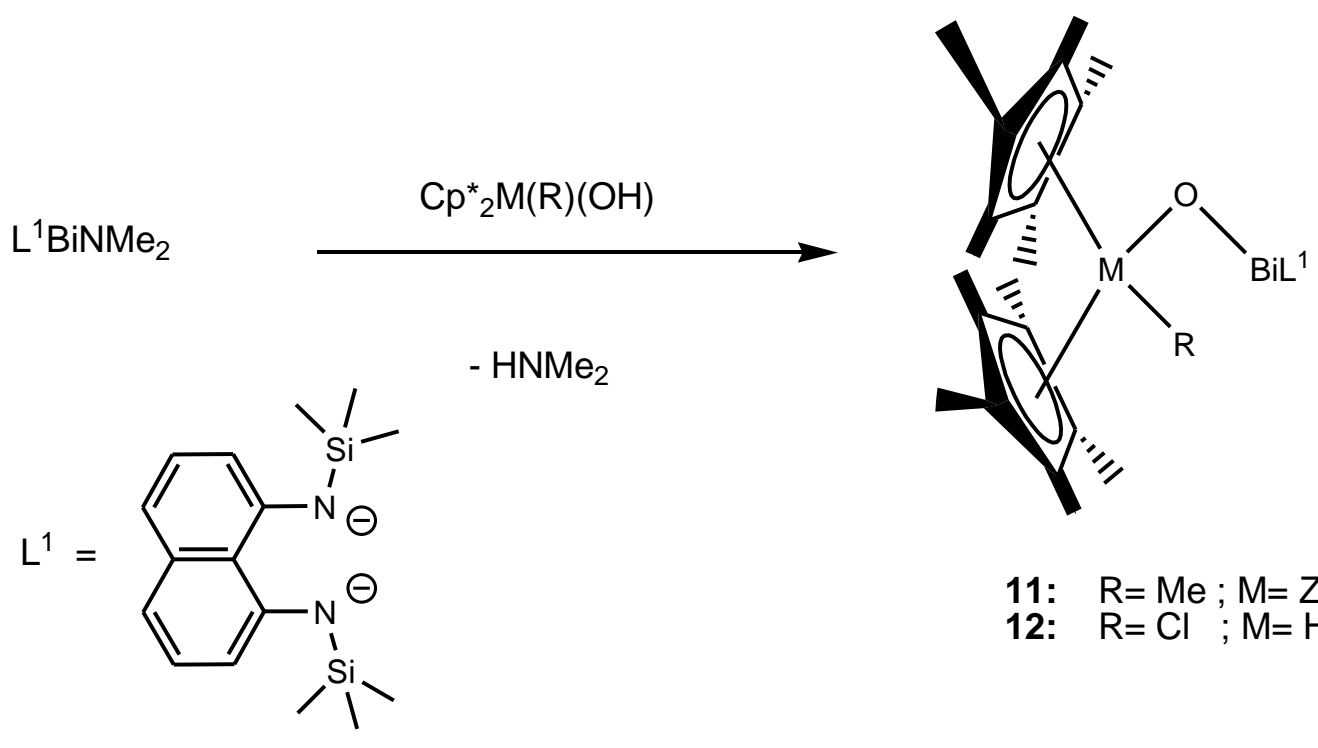

11: $\mathrm{R}=\mathrm{Me} ; \mathrm{M}=\mathrm{Zr}$

12: $\mathrm{R}=\mathrm{Cl} ; \mathrm{M}=\mathrm{Hf}$ 
Yellow crystals of $\mathbf{1 1}$ suitable for single-crystal X-ray diffraction study were obtained from a saturated solution of $n$-hexane at $-30{ }^{\circ} \mathrm{C}$ and for those of $\mathbf{1 2}$ from a mixture of $n$ hexane/toluene solution at $-30^{\circ} \mathrm{C}$. Compounds 11 and 12 crystallize in the monoclinic space group $P n$ with one molecule in the asymmetric unit. Both absolute structures could be determined unequivocally. In $\mathbf{1 1}$ the bismuth atom is bonded through an oxygen atom to zirconium and in $\mathbf{1 2}$ to hafnium, respectively, and both contain a bent Bi-O-M (M=Zr, Hf) core as revealed by the corresponding bond angles $\left(138.23(19)^{\circ}\right.$ and $\left.134.55(18)^{\circ}\right)$. Like the other structures, the bismuth atom shows the anticipated trigonal pyramidal coordination geometry with two nitrogen atoms of the $1,8-\mathrm{C}_{10} \mathrm{H}_{6}\left(\mathrm{NSiMe}_{3}\right)_{2}$ ligand and one $(\mu-\mathrm{O})$ atom. The zirconium and hafnium metal atoms show a distorted tetragonal geometry each (Figures 11 and 12).

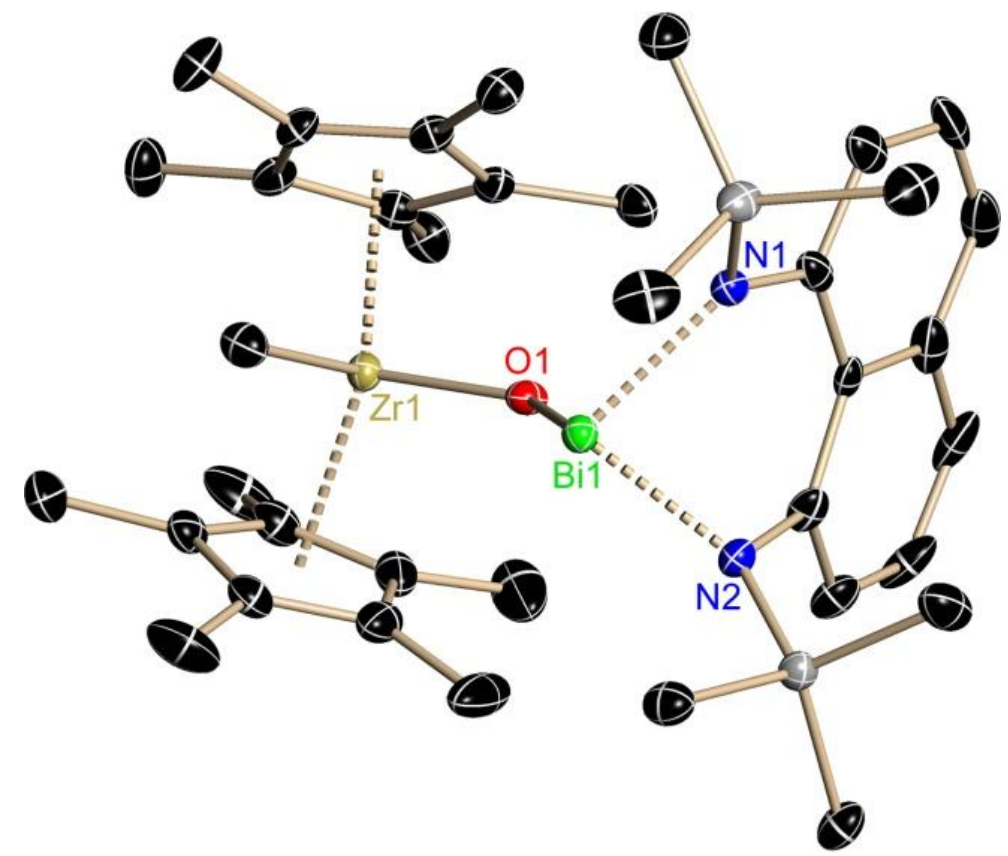

Figure 11. Molecular structure of 11. Anisotropic displacement parameters are depicted at the $50 \%$ probability level. $\mathrm{H}$ atoms are omitted for clarity. Selected bond lengths $[\AA]$ and angles []: Bi1-O1 2.032(3), Zr1-O1 1.982(3), Zr1-C37 2.292(5), Bi1-N1 2.169(4), Bi1-N2 2.139(4), Zr1-O1-Bi1 138.23(19), N1-Bi1-N2 84.09(16), O1-Zr1-C37 92.07(18), O1-Bi1-N1 98.42(15), O1-Bi1-N2 93.82(15). 
The coordination sphere around the transition metals is quite similar: the zirconium metal in $\mathbf{1 1}$ accommodates two of the $\eta^{5}$-coordinated $\mathrm{Cp} *$ ligands, the $\mu$-bridging $\mathrm{O}$ atom, and one Me group, whereas at the hafnium atom in $\mathbf{1 2}$ the latter is replaced by a chlorine atom. The Zr-O bond length (1.982(3) $\AA$ ) falls between those found in $\operatorname{LMeAl}(\mu-\mathrm{O}) \mathrm{ZrRCp}_{2}$ (av 1.92 $\AA)^{106}$ and $\mathrm{Ti}_{4} \mathrm{Zr}_{4} \mathrm{O}_{6}(\mathrm{OBu})_{4}(\mathrm{OMc})_{16}(\mathrm{OMc}=$ methacrylate, av $\mathrm{Zr}-\mathrm{O} 2.17 \AA){ }^{107}$ In 6 the Hf-O bond length $(1.957(3) \AA)$ is longer than that in $\operatorname{LAlMe}(\mu-\mathrm{O}) \mathrm{HfMeCp}_{2}(1.919 \AA) .{ }^{101 \mathrm{c}}$ The Bi-

O bond length in compounds 8-12 (av 2.038 $\AA$ ) is comparable to those observed in $\left(\mathrm{BiTi}_{2} \mathrm{O}(\mathrm{O} i \mathrm{Pr})_{9}(2.090 \AA)^{108}\right.$ and $\left[\left(\mathrm{Cp}^{*} \mathrm{MoO}_{3}\right)_{2} \mathrm{BiPh}_{3}\right](2.201 \AA)^{109}$ but considerably shorter than that found in $\left[\left\{\mathrm{Bi}(\mathrm{Hsal})_{3}\right\}_{2}\left\{\mathrm{Al}(\mathrm{acac})_{3}\right\}\right](2.765 \AA) .{ }^{100}$

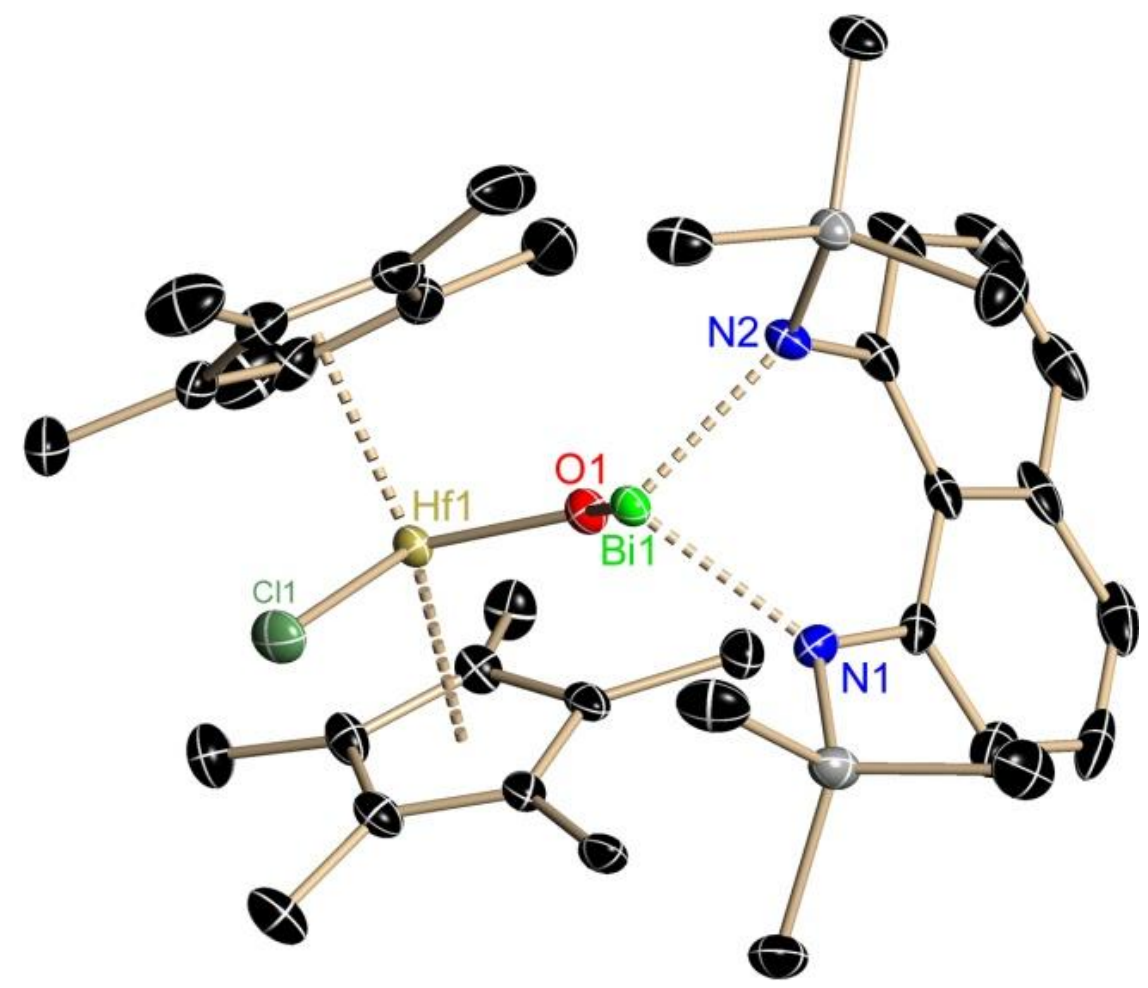

Figure 12. Molecular structure of 12. Anisotropic displacement parameters are depicted at the $50 \%$ probability level. $\mathrm{H}$ atoms are omitted for clarity. Selected bond lengths $[\AA]$ and angles

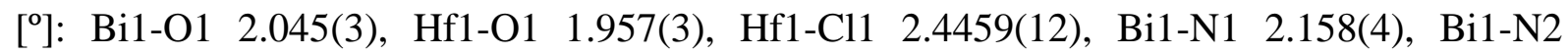
2.139(4), Hf1-O1-Bi1 134.55(18), N1-Bi1-N2 86.63(16), O1-Hf1-Cl1 92.5410, O1-Bi1-N1 98.68(15), O1-Bi1-N2 93.09(14). 


\subsubsection{Structural Comparison of compounds 8-12}

The $\mathrm{Bi}-\mathrm{N}$ bond distances span a very narrow range of $2.115(4)$ in $\mathbf{8}$ to $2.169(4) \AA$ in $\mathbf{1 1}$ while the Bi-O distances vary by about $0.08 \AA$ from $1.978(3)$ in 8 to $2.0552(11) \AA$ in $\mathbf{1 0}$. The shortest $\mathrm{Bi}-\mathrm{O}$ bond in the aluminum derivative $\mathbf{8}$ correlates with the widest $\mathrm{Bi}-\mathrm{O}-\mathrm{M}$ angle $\left(160.7(2)^{\circ}\right.$ in $\left.\mathbf{8}\right)$ while the longer distance in $\mathbf{1 0}$ tolerates the most acute angle $\left(112.58(6)^{\circ}\right)$. The angle of the $\mathrm{Bi}-\mathrm{O}$ bond to the $\mathrm{BiN}_{2}$ plane is remarkably invariant and widens only by less than $4^{\circ}$ from $95.2^{\circ}$ in $\mathbf{9}$ to $98.9^{\circ}$ in $\mathbf{1 1}$ and $\mathbf{1 2}$, demonstrating that the lone-pair character at the bismuth atom is almost independent from the nature of the second organometallic fragment. The angle of the $\mathrm{M}-\mathrm{O}$ bond relative to the $\mathrm{ML}_{2}$ plane varies much more (from $99.1^{\circ}$ in $\mathbf{1 0}$ to $140.3^{\circ}$ in 11), reflecting the dependence of the angle on the steric requirements of the organometallic fragment.

\subsection{Synthesis, Structure and Reactivity of Organobismuth(III), Bismuth Chalcogenide and Dibismuthine Complexes}

Organobismuth compounds have attracted interest because of the Lewis acidity and the nontoxicity of the bismuth atom. Trivalent organobismuth compounds with electronegative substituents, such as halogen and oxygen atoms, are well-known to behave as good Lewis acids and to form tetracoordinate structures easily by the coordination with Lewis bases. ${ }^{110}$ Bismuth halide fragments have been employed as a building block for the formation of twodimensional coordination networks with tunable conducting/semiconducting properties. ${ }^{111}$ The application of organobismuth reagents in organic synthesis is still very limited. ${ }^{112}$ Organobismuth compounds are normally nontoxic and potentially meet the recent requirement for the reagent, process, and product of little or no risk to humans and environment, which is a major contemporary concern in the chemistry community. The unique performance of bismuth salts as Lewis acid catalysts or reagents is becoming 
evident $^{113}$, and organobismuth(III) has been used in the oxidation of alcohols to aldehydes and ketones under mild conditions. ${ }^{114}$ Herein we report the preparation and stabilization of organobismuth(III) compounds, low-valent bismuthane and organobismuth chalcogenides.

\subsubsection{Synthesis, Spectroscopic Characterization and Structure of Complexes [1,8- $\left.\mathrm{C}_{10} \mathrm{H}_{6}\left(\mathrm{NSiMe}_{3}\right)_{2}\right] \mathrm{BiR}\left(\mathrm{R}=\mathrm{Cl}(13), \mathrm{CCPh}(14), \mathrm{Cp} *(15), \mathrm{Me}(16), \mathrm{OPh}(17), \mathrm{NH}_{2}(18)\right.$}

Metathesis of amide to chloride can be achieved by treatment of $n$-hexane solution of $\mathbf{1}$ with $\mathrm{ClSiMe}_{3}$. Organic groups can be easily introduced in $\mathbf{1}$ by elimination of $\mathrm{HNMe}_{2}$ using acidic reagents. Treatment of $\mathbf{1}$ with stoichiometric amounts of $\mathrm{PhCCH}, \mathrm{Cp} * \mathrm{H}$ and $\mathrm{PhOH}$ in $n$-hexane results in the formation of $\operatorname{LBiCCPh}(\mathbf{1 4}), \operatorname{LBiCp} *(\mathbf{1 5})$, and $\mathrm{LBiOPh}(\mathbf{1 7})[\mathrm{L}=1,8$ $\left.\mathrm{C}_{10} \mathrm{H}_{6}\left(\mathrm{NSiMe}_{3}\right)_{2}\right]$, respectively under elimination of $\mathrm{HNMe}_{2}$ as shown in Scheme 18. $\mathrm{LBiNH}_{2}$

\section{Scheme 18}

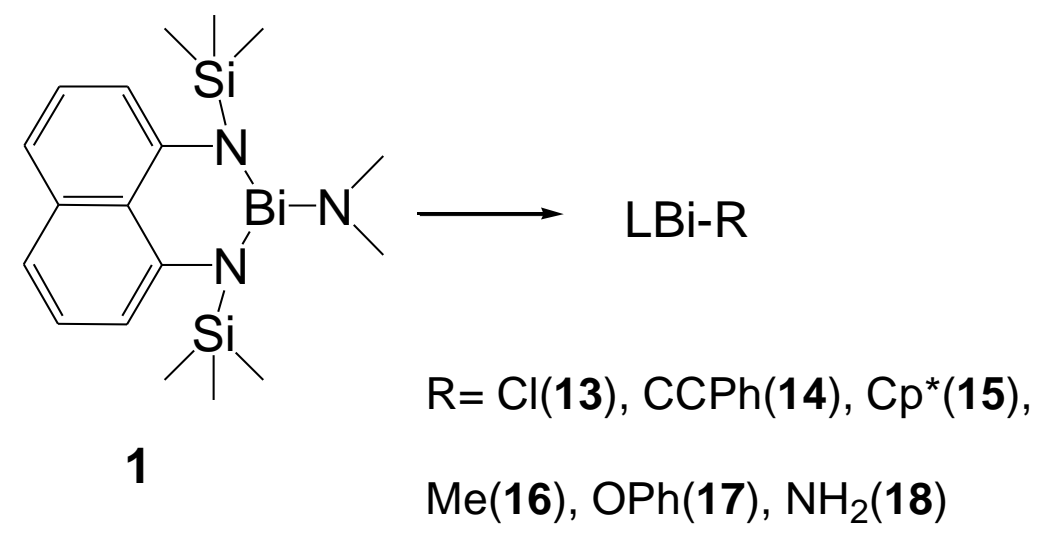

(18) was prepared as an oily compound by bubbling dry ammonia gas through the $n$-hexane solution of $\mathbf{1}$, whereas LBiMe (16) can be synthesized by slow addition of $\mathrm{AlMe}_{3}$ in $n$-hexane to the $n$-hexane solution of $\mathbf{1}$. The ${ }^{1} \mathrm{H}$ NMR spectrum of each reaction mixture of compounds 13-18 shows almost quantitative conversion of the precursors to products, as revealed by the absence of $\mathrm{NMe}_{2}$ resonance. The ${ }^{1} \mathrm{H}$ NMR spectra of compounds 13-18 in $\mathrm{C}_{6} \mathrm{D}_{6}$ at room temperature show singlet resonances for $\mathrm{SiMe}_{3}$ groups. The ${ }^{1} \mathrm{H}$ NMR spectrum of $\mathbf{1 5}$ displays one resonance at $\delta 1.86 \mathrm{ppm}$ which can be attributed to the Me protons of $\mathrm{Cp}^{*}$, whereas the 
particular BiMe group in $\mathbf{1 6}$ resonates as a singlet at $\delta 0.43 \mathrm{ppm}$. In compound $\mathbf{1 8}$ a broad singlet resonance at $\delta 5.38 \mathrm{ppm}$ can be assigned to the protons of the $\mathrm{NH}_{2}$ group. The ${ }^{13} \mathrm{C}$ NMR spectrum of 15 reveals two resonances ( $\delta$ 10.4, $3.3 \mathrm{ppm}$ ), which can be assigned to the carbon resonances arising from $\mathrm{SiMe}_{3}$ and $\mathrm{Bi}-\mathrm{Cp}^{*}$, respectively. Compound $\mathbf{1 3}$ is a red crystalline solid which is soluble in common organic solvents such as toluene and THF, and it is stable in the solid state at room temperature for several months under an inert atmosphere. Organobismuth compounds 14-17 are orange crystalline solids which are soluble in toluene, THF, and $n$-hexane. Compounds 14-18 are air and moisture sensitive and hydrolyze upon exposure to air.

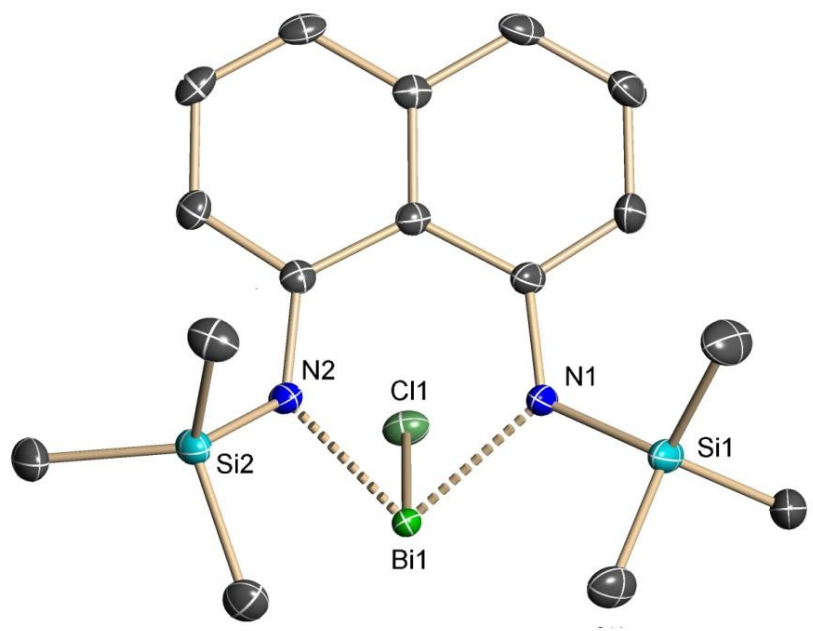

Figure 13. Molecular structure of 13. Thermal ellipsoids are set at 50\% probability level. $\mathrm{H}$ atoms are omitted for clarity. Selected bond lengths $\left[\AA \AA^{\circ}\right]$ and angles $\left[^{\circ}\right]$ : Bi1-N1 2.1569(18), Bi1-N2 2.127(2), Bi1-Cl 2.4784(6), Si1-N1 1.735(2), Si2-N2 1.745(2), N1-Bi1-N2 83.88, Cl-Bi1-N1 92.10(6), Cl-Bi1-N2 95.72(6), Si1-N1-Bi1 119.61(10), Si2-N2-Bi1 118.80(10).

\subsubsection{Molecular Structure Description of Compounds 13-16}

Single crystals suitable for X-ray structures of 14-16 were obtained from saturated solution of $n$-hexane at $-30{ }^{\circ} \mathrm{C}$ and for those of $\mathbf{1 3}$ from a mixture of $n$-hexane/toluene solution at $-30{ }^{\circ} \mathrm{C}$. The coordination geometry around the bismuth atom in compounds $\mathbf{1 3 - 1 6}$ 
is that of a distorted trigonal-pyramidal arrangement with a stereochemically active electron lone pair. Compound $\mathbf{1 3}$ crystallizes in the tetragonal space group $I \overline{4}$ with one molecule in the asymmetric unit (Figure 13). The Bi-Cl distance (2.4784(6) $\AA$ ) is shorter than those that have been reported for complexes $\left[2,6-\left(\mathrm{Me}_{2} \mathrm{NCH}_{2}\right)_{2} \mathrm{C}_{6} \mathrm{H}_{3}\right]_{2}-\mathrm{BiCl}(2.6086(13) \AA)^{115}$ and $\left[\left\{\mathrm{HC}\left(\mathrm{Et}_{2} \mathrm{NCH}_{2} \mathrm{CH}_{2} \mathrm{NCMe}\right)_{2}\right\} \mathrm{BiCl}_{2}\right] \quad(\text { av } 2.7055 \AA)^{116}$ but is comparable to that of characteristic Bi-chlorine covalent bond $\left(\Sigma_{\text {cov }}(\mathrm{Bi}-\mathrm{Cl}) 2.51 \AA\right)^{117}$ Compounds $\mathbf{1 4}$ and $\mathbf{1 6}$ crystallize in the monoclinic space group $P 2_{1} / n$ with two molecules in the asymmetric unit (Figures 14, 16).

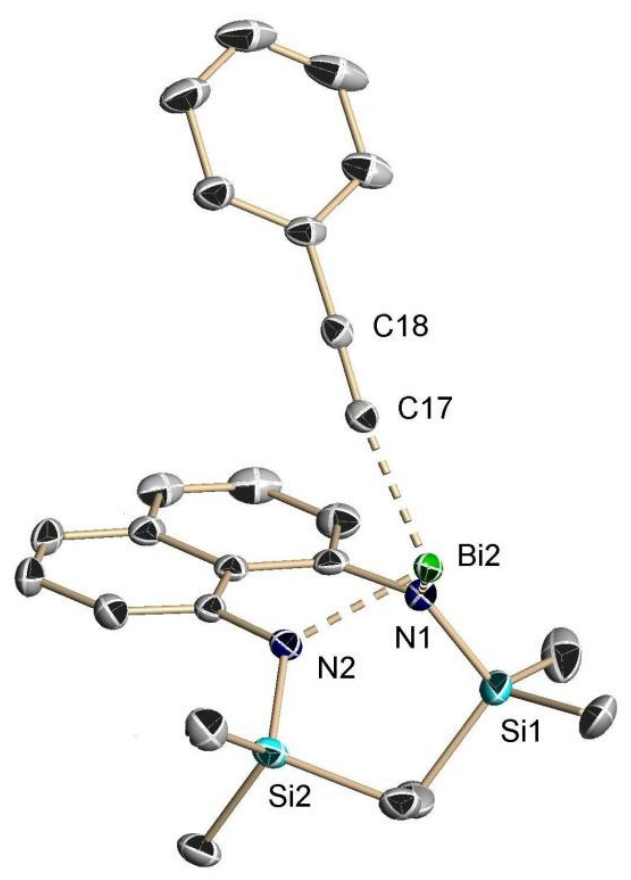

Figure 14. Molecular structure of 14. Thermal ellipsoids are set at 50\% probability level. Only one of the two crystallographically independent molecules is shown. $\mathrm{H}$ atoms are omitted for clarity. Selected bond lengths $[\AA]$ and angles $\left[^{\circ}\right]$ : Bi2-N1 2.142(2), Bi2-N2 2.145(2), Bi2-C17 2.212(3), C17-C18 1.202(4), Si1-N1 1.733(2), Si2-N2 1.738(2), N1-Bi2-N2 84.88(8), C17-Bi2-N1 89.81(9), C17-Bi2-N2 94.91(9), Si1-N1-Bi2 119.55(12), Si2-N2-Bi2 120.86(11). 
The Bi-C bond length (av $2.2115 \AA$ ) in $\mathbf{1 4}$ is shorter than that in $\left[t \mathrm{BuN}\left(\mathrm{CH}_{2} \mathrm{C}_{6} \mathrm{H}_{4}\right)_{2} \mathrm{BiCCPh}\right](2.289(4) \AA) .{ }^{95}$ The Bi-Me distance in 16 (av $2.2485 \AA$ ) falls between those found in $\left[2,6-\left(\mathrm{Me}_{2} \mathrm{NCH}_{2}\right)_{2} \mathrm{C}_{6} \mathrm{H}_{3}\right](\mathrm{Me}) \mathrm{BiI} \quad(2.224(10) \quad \AA)^{115}$ and $\left[t \mathrm{BuN}\left(\mathrm{CH}_{2} \mathrm{C}_{6} \mathrm{H}_{4}\right)_{2} \mathrm{BiMe}\right](2.264(6) \AA) .{ }^{95}$ Compound 15 crystallizes in the triclinic space group $P \overline{1}$ with two molecules in the asymmetric unit (Figure 15). The Bi-C bond length pattern with one short, two intermediate and two longer distances (av 2.3638, 2.7616, 2.7745, 3.1900, $3.1998 \AA$ ) between $\mathrm{Cp}^{*}$ and bismuth resembles a scenario between an $\eta^{1}$ or $\eta^{3}$ chelating mode. The $\mathrm{Bi}-\mathrm{XB} 1 \mathrm{~A}_{\mathrm{B}}\left(\mathrm{XB} 1 \mathrm{~A}_{\mathrm{B}}=\right.$ centroid of the $\mathrm{Cp} *$ ring $)$ distance $(2.6059 \AA)$ in 15 is longer than those in $\left[\left(\mathrm{C}_{5} \mathrm{HR}_{4}\right) \mathrm{BiCl}_{2}\right]_{2}\left(\mathrm{R}=\mathrm{CHMe}_{2}\right)(\mathrm{Bi}-\mathrm{X} 1 \mathrm{~A}$, av $2.3495 \AA) .{ }^{118}$ In compounds 13-16 the Bi-N bond lengths are in the range of 2.127(2) $\AA$ (in 13) to 2.1995(16) $\AA$ (in 15) and the N-Bi-N angles are ranging from $82.47(7)^{\circ}$ (in 16) to $84.88(8)^{\circ}$ (in 14), which are comparable to those observed in $\mathbf{1}$.

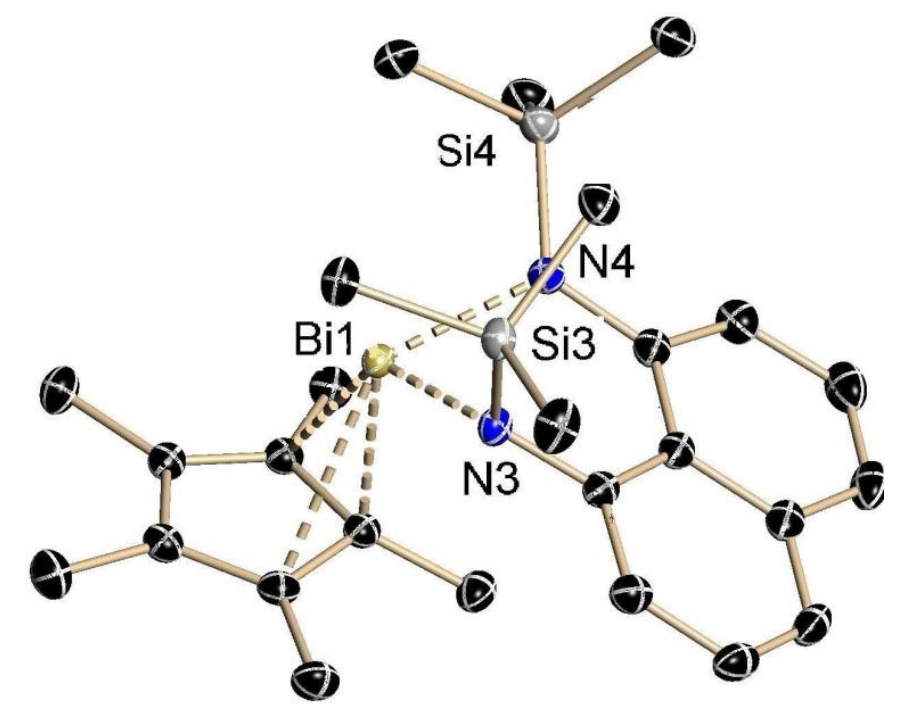

Figure 15. Molecular structure of 15. Thermal ellipsoids are set at 50\% probability level. Only one of the two crystallographically independent molecules is shown. $\mathrm{H}$ atoms are omitted for clarity. Selected bond lengths $[\AA]$ and angles $\left[^{\circ}\right]$ : Bi2-N1 2.1854(16), Bi2-N2 2.1568(15), Bi1-X1A 2.62137(10), Si1-N1 1.7373(16), Si2-N2 1.7285(17), N1-Bi2-N2 
83.46(6), X1A-Bi2-N1 123.53(4), X1A-Bi2-N2 118.55(4), Si1-N1-Bi2 117.64(8), Si2-N2-

$\mathrm{Bi} 2$ 117.65(8). $(\mathrm{X} 1 \mathrm{~A}=$ centroid of the $\mathrm{Cp} *$ ring $)$

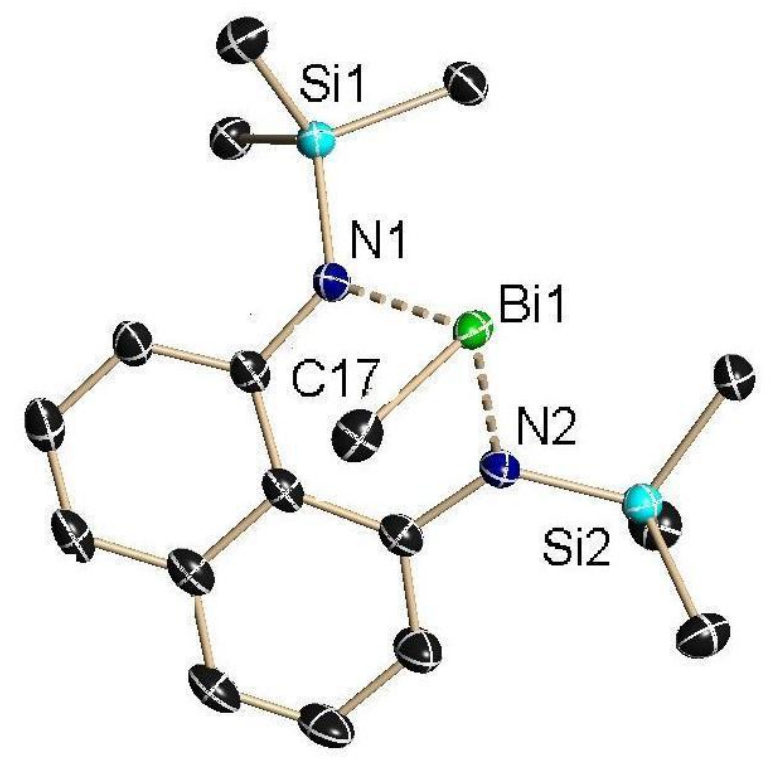

Figure 16. Molecular structure of 16. Thermal ellipsoids are set at 50\% probability level. Only one of the two crystallographically independent molecules is shown. $\mathrm{H}$ atoms are omitted for clarity. Selected bond lengths $[\AA]$ and angles $\left[^{\circ}\right]$ : Bi1-N1 2.1561(19), Bi1-N2 2.1733(19), Bi1-C17 2.249(3), Si1-N1 1.737(2), Si2-N2 1.745(2), N1-Bi2-N2 83.69(8), C17-Bi1-N1 93.32(9), C17-Bi1-N2 94.75(9), Si1-N1-Bi1 121.10(10), Si2-N2-Bi1 $118.45(8)$

\subsubsection{Synthesis, Spectroscopic Characterization and Structure of Organobismuth} Chalcogenide Complex: Synthesis of $\left[1,8-\mathrm{C}_{10} \mathrm{H}_{6}\left(\mathrm{NSiMe}_{3}\right)_{2} \mathrm{Bi}\right]_{2} \mathrm{~S}(19)$

The first bis(diorganobismuth) chalcogenides, $\left(\mathrm{R}_{2} \mathrm{Bi}\right)_{2} \mathrm{E}(\mathrm{E}=\mathrm{O}, \mathrm{S}, \mathrm{Se}, \mathrm{Te})$ were prepared several years ago by chalcogen insertion into bismuth-bismuth bonds. ${ }^{119,120}$ Later also reactions between diorganobismuth halides and sodium chalcogenides were accomplished. ${ }^{121}$ The examples with known crystal structures are the mesityl derivatives $\left(\mathrm{R}_{2} \mathrm{Bi}\right)_{2} \mathrm{E}[\mathrm{E}=\mathrm{O}, \mathrm{S}$, 
$\left.\mathrm{Se} ; \quad \mathrm{R}=2,4,6-\mathrm{Me}_{3} \mathrm{C}_{6} \mathrm{H}_{2}\right],{ }^{122} \quad\left[2,6-\left(\mathrm{Me}_{2} \mathrm{NCH}_{2}\right)_{2} \mathrm{C}_{6} \mathrm{H}_{3} \mathrm{BiS}\right]_{2},{ }^{45} \quad\left(\mathrm{R}_{2} \mathrm{Bi}\right)_{2} \mathrm{E} \quad[\mathrm{E} \quad=\quad \mathrm{S}, \quad \mathrm{Te} ;$ $\left.\mathrm{R}=\mathrm{CH}\left(\mathrm{SiMe}_{3}\right)_{2}\right]^{123}$ and $\left[2,6-\left(t-\mathrm{BuOCH}_{2}\right)_{2} \mathrm{C}_{6} \mathrm{H}_{3} \mathrm{BiS}\right]_{2} .{ }^{124}$

The reaction of $\mathbf{1}$ in the presence of equivalent amounts of elemental sulfur at room temperature in $n$-hexane leads after three days to compound 19 in good yield (Scheme 19). Compound $\mathbf{1 9}$ is an orange crystalline solid, which is soluble in organic solvents such as $n$ hexane, THF, and toluene. The ${ }^{1} \mathrm{H}$ NMR spectrum of 19 exhibits two different resonances $(\delta$ 0.169 and $0.131 \mathrm{ppm})$ for the $\mathrm{SiMe}_{3}$ groups.

\section{Scheme 19}

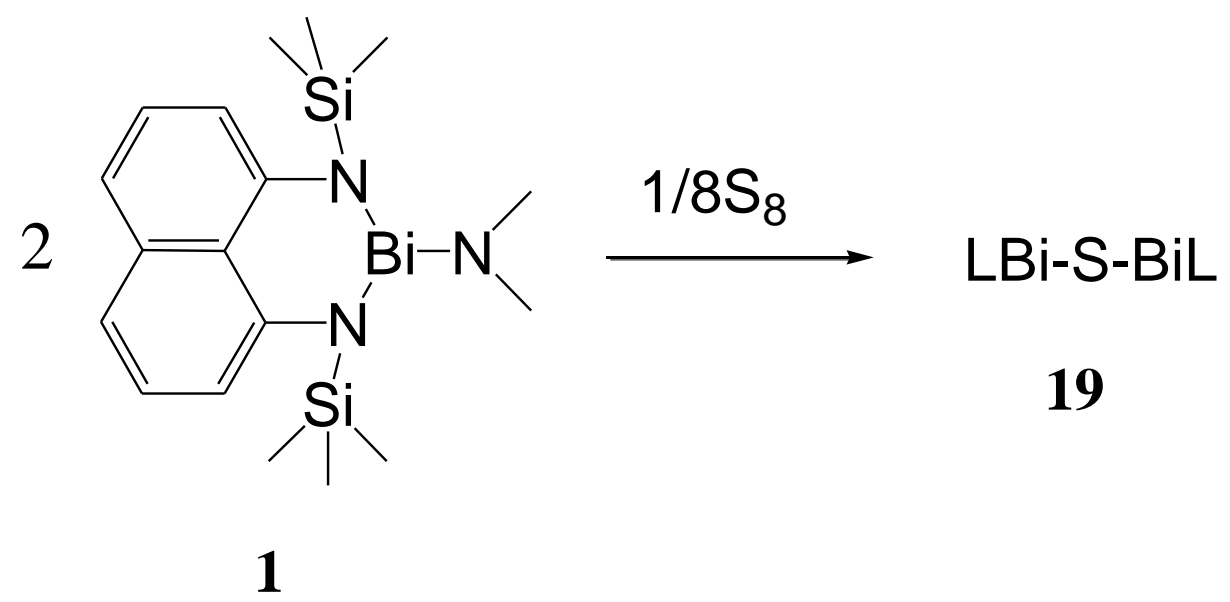

In 19 the bismuth atoms are bound by a bent $\mathrm{Bi}(\mu-\mathrm{S}) \mathrm{Bi}$ core as revealed by the bond angle of av $113.18^{\circ}$. The bismuth-sulfur distances in $\mathbf{1 9}$ (av 2.5383 $\AA$ ) are similar to those in $\left[\left\{2-\left(\mathrm{Me}_{2} \mathrm{NCH}_{2}\right) \mathrm{C}_{6} \mathrm{H}_{4}\right\}_{2} \mathrm{Bi}\right]_{2} \mathrm{~S}(2.5558(17) \AA)^{45}$ and $\left(\mathrm{Mes}_{2} \mathrm{Bi}\right)_{2} \mathrm{~S}(\text { av } 2.5325 \AA)^{121}$, while the $\mathrm{Bi}(\mu-\mathrm{S}) \mathrm{Bi}$ angle in $\mathbf{1 9}$ is considerably larger when compared with those of the latter compounds $\left.\left(98.17(8)^{\circ}\right), 98.7(2)^{\circ}\right)$. 


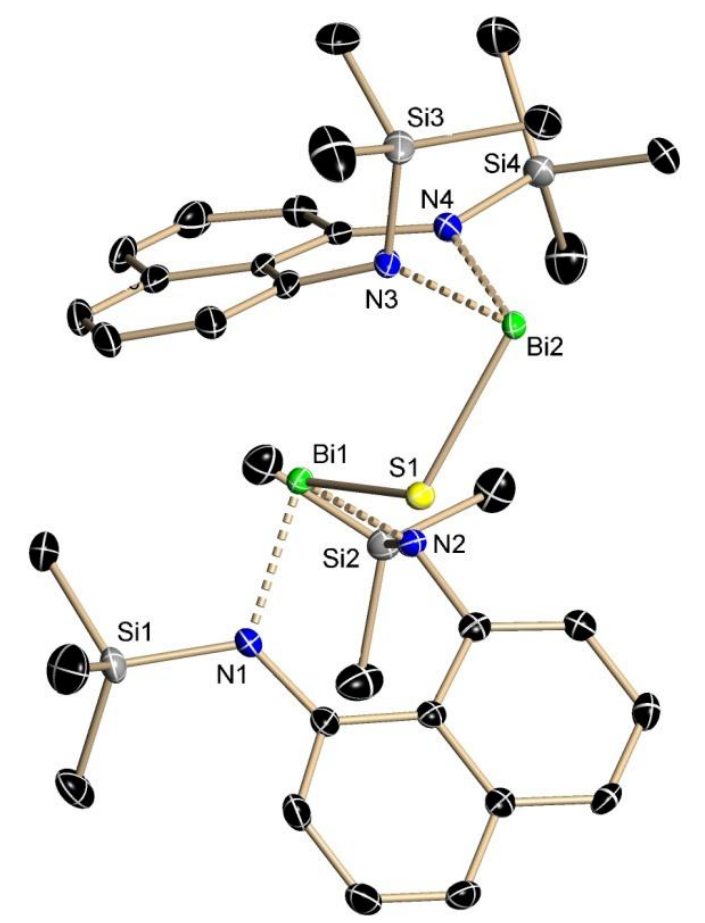

Figure 17. Molecular structure of 19. Thermal ellipsoids are set at 50\% probability level. Only one of the two crystallographically independent molecules is shown. $\mathrm{H}$ atoms are omitted for clarity. Selected bond lengths $[\AA ̊ \AA]$ and angles $\left[^{\circ}\right]$ : Bi1-N1 2.167(2), Bi1-N2 2.138(2), Bi2-N3 2.144(2), Bi2-N4 2.170(2), N1-Si1 1.743(2), N2-Si2 1.733(2), N3-Si3 1.725(2), N4-Si4 1.751(2), Bi1-S1 2.5386(7), Bi2-S1 2.5381(7), Bi1-S1-Bi2 113.47(3), N1Bi1-N2 84.68(8), N3-Bi2-N4 84.00(9), N1-Bi1-S1 92.10(6), N2-Bi1-S1 95.10(6), N3-Bi2-S1 94.96(6), N4-Bi2-S1 98.22(6), Bi1-S1-Bi2 112.89(3).

\subsubsection{Synthesis, Spectroscopic Characterization and Structure of Low-valent Dibismuthine} Complex: Synthesis of $\left[1,8-C_{10} \mathrm{H}_{6}\left(\mathrm{NSiMe}_{3}\right)_{2} \mathrm{Bi}\right]_{2}(20)$

There are very few compounds with known crystal structures of compounds containing bismuth-bismuth bonds. Interesting aspects of the structures of dibismuthines are the conformation and the possibility of the formation of bismuth chains through alternating Bi-Bi bonds and intermolecular $\mathrm{Bi} \cdots \mathrm{Bi}$ contacts. The first crystallographically characterized tetraorganyl derivative of bismuth(II) is tetraphenyldibismuthine, $\mathrm{Ph}_{2} \mathrm{Bi}^{-} \mathrm{BiPh}_{2} .{ }^{125}$ The molecule has a staggered trans conformation. The coordination at the bismuth atoms is 
essentially trigonal pyramidal. The bond angles about bismuth are significantly smaller than the tetrahedral value. The dibismuthine $\left(\mathrm{Me}_{3} \mathrm{Si}\right)_{2} \mathrm{Bi}-\mathrm{Bi}\left(\mathrm{SiMe}_{3}\right)_{2}$, which does not contain a direct $\mathrm{Bi}-\mathrm{C}$ bond, has the same molecular structure as tetraphenyldibismuthine with a staggered trans conformation of the substituents. ${ }^{126}$ However, the crystal structure is different. There are linear zigzag bismuth chains with alternating $\mathrm{Bi}-\mathrm{Bi}$ bonds and shortened intermolecular $\mathrm{Bi} \cdots \mathrm{Bi}$ contacts in the crystalline state. The shortest $\mathrm{Bi}-\mathrm{Bi}$ single bond (2.947 $\AA$ ) was found in the unusual bismuth-arene adduct, $\left(\mu-\eta^{6}-\mathrm{C}_{6} \mathrm{Me}_{6}\right)\left[\mathrm{Bi}_{2}\left(\mu-\mathrm{O}_{2} \mathrm{CCF}_{3}\right)_{4}\right]_{2},{ }^{127}$ which is the first example of a carboxylato derivative containing the bismuth atoms in a formal +2 oxidation state.

Reaction of $\mathrm{PhSiH}_{3}$ with 1 in $n$-hexane results in a Bi-Bi bond formation (Scheme 20). Compound 20 is obtained as a red crystalline solid which is air and moisture sensitive but stable in the solid state under an inert atmosphere at room temperature. In the ${ }^{1} \mathrm{H}$ NMR spectrum of 20 the 18 protons of $\mathrm{SiMe}_{3}$ resonate as a singlet $(\delta 0.15 \mathrm{ppm})$ and the aromatic protons appear in the range of $\delta 7.13-7.22 \mathrm{ppm}$.

\section{Scheme 20}

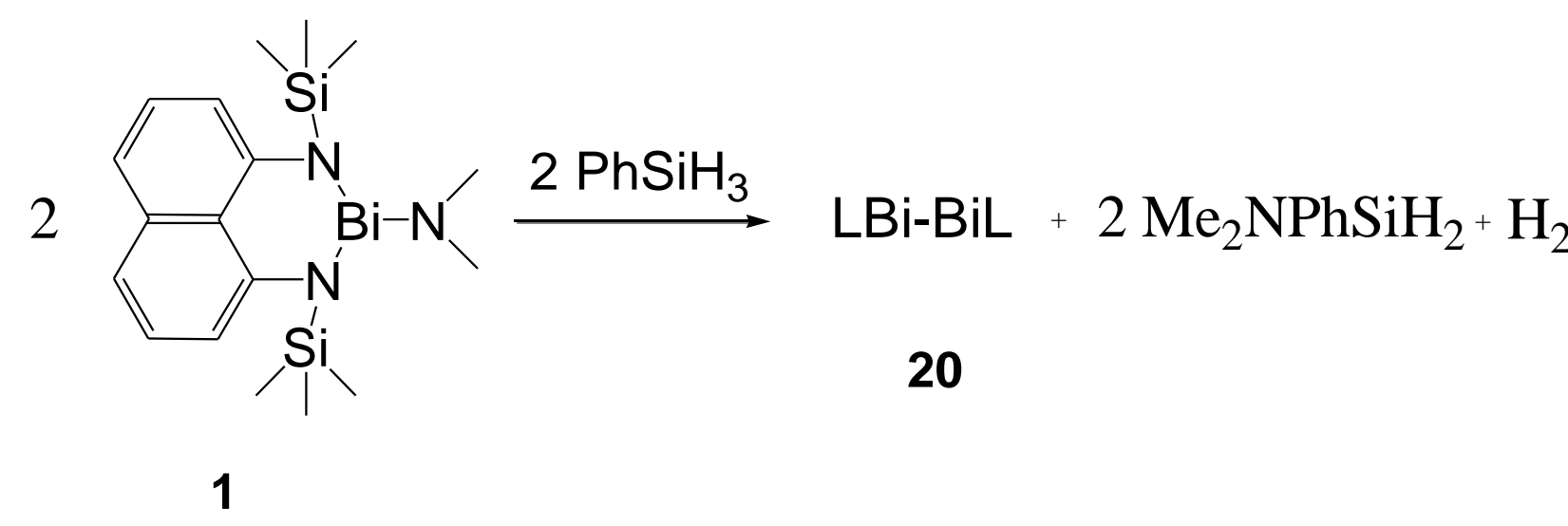

Compound LBi-BiL (20) crystallizes in the monoclinic space group $P 2_{1} / c$ with one molecule in the asymmetric unit (Figure 18). The N,N'-disubstituted 1,8-diaminonaphthalene ligands of $\mathbf{2 0}$ are in a trans conformation to each other and the N-Bi-Bi angles lie in the range 
between av $89.88^{\circ}$ and av $89.03^{\circ}$. The $\mathrm{Bi}-\mathrm{Bi}$ bond distance of $3.0197(2) \AA$ corresponds to a normal bismuth-bismuth single bond as found in $\left(\mathrm{Me}_{3} \mathrm{Si}\right)_{4} \mathrm{Bi}_{2}(3.035(3) \AA)^{126}$ or $\mathrm{R}_{4} \mathrm{Bi}_{4}$ $\left(\mathrm{R}=\left(\mathrm{Me}_{3} \mathrm{Si}\right)_{2} \mathrm{CH} ; \text { av } 3.005 \AA\right)^{56}$.

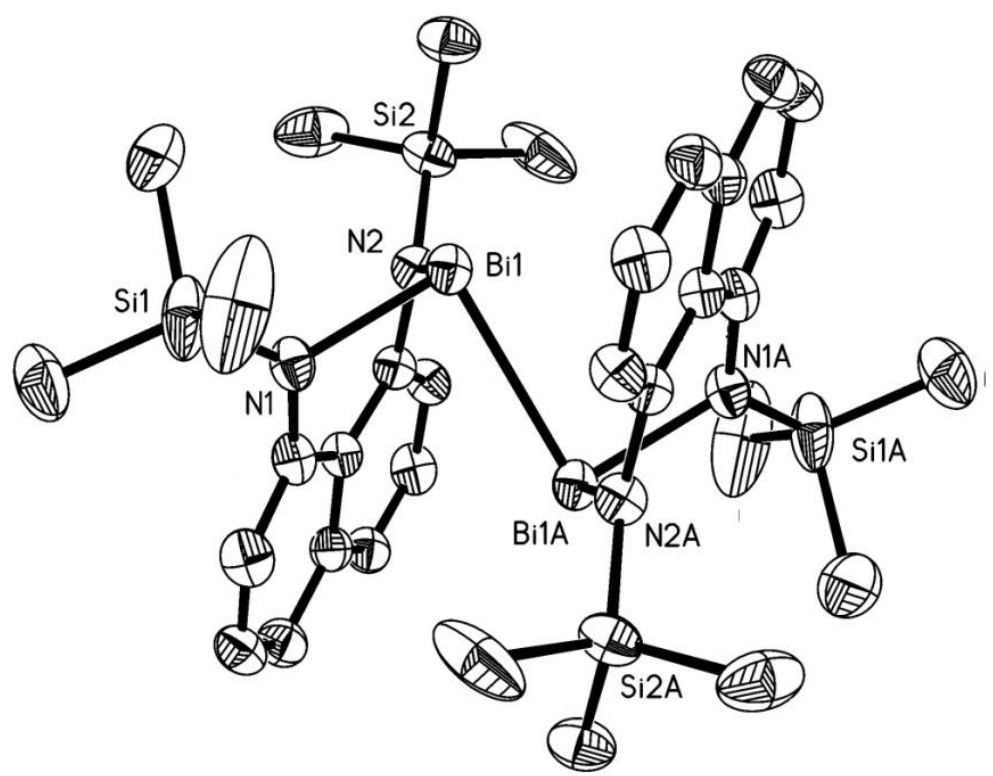

Figure 18. Molecular structure of 20. Thermal ellipsoids are set at 50\% probability level. $\mathrm{H}$ atoms are omitted for clarity. Selected bond lengths $[\AA]$ and angles $\left[^{\circ}\right]$ : $\operatorname{Bi}(1)-\mathrm{N}(1) 2.1648(11)$, Bi(1)-N(2) 2.1660(12), Bi1A-N1A 2.1621(13), Bi1A-N2A 2.1646(11), N1-Si1 1.7432(12), N2-Si2 1.7422(13), N1A -Si1A 1.7470(13), N2A -Si2A 1.7475(12), Bi1-Bi1A 3.0197, N1Bi1-N2 84.51(5), N1A-Bi1A-N2A 85.02(4), N1-Bi1-Bi1A 89.82(3), N2-Bi1-Bi1A 88.87(3), N1A-Bi1A-Bi1 89.95(3), N2A-Bi1A-Bi1 89.19(3). 
2.4 Synthesis, Characterization, and X-ray Single Crystal Structures of N,N'Bis(trimethylsilyl)diphenyliminophosphonamide Aluminum Halide, Hydride, Amide and Alkylate.

Monoanionic $N, N^{\prime}$-chelating organic ligands such as $\beta$-diketiminate, guanidinate and amidinate have attracted growing interest in organometallic chemistry in the last decade due to their capability to coordinate very flexible to the metal center as monodentate $\left(\eta^{1}\right)$, chelating $\left(\eta^{2}\right)$ or bridging monodentate $\left(\mu-\eta^{1}-\eta^{1}\right)$ four-electron donor. ${ }^{128}$ One of the most fruitful systems has been the $\left[\mathrm{R}-\mathrm{N}-\mathrm{E}\left(\mathrm{R}^{\prime}\right)_{\mathrm{n}} \mathrm{N}-\mathrm{R}\right]^{-}(\mathrm{E}=\mathrm{C}, \mathrm{S}, \mathrm{n}=1 ; \mathrm{Si}, \mathrm{P}, \mathrm{n}=2)$ ligand coordinating with two nitrogen atoms. Moreover, they were found very useful in catalysis, material science (i.e. precursors for CVD) and organic-inorganic hybrids since their steric and electronic properties can easily be tuned by modification of the organic substituents $\mathrm{R}$ and $\mathrm{R}^{\prime}$.

A number of $\mathrm{PN}_{2}$ complexes of the metals have been prepared and characterized; ${ }^{129-132}$ many of these compounds were synthesized by the reaction of the $\left[\mathrm{Ph}_{2} \mathrm{P}\left(\mathrm{NSiMe}_{3}\right)_{2}\right]^{-}$ligand with the corresponding metal chloride. Monosubstituted complexes are generally accessible via this route and are typically dinuclear with halide bridges. Amine elimination is also a complementary route for the preparation of both mono- and disubstituted $\mathrm{PN}_{2}$ complexes. ${ }^{133}$ Herein, we report the synthesis and solid-state structures of aluminum complexes with the $\mathrm{Ph}_{2} \mathrm{P}\left(\mathrm{NSiMe}_{3}\right)_{2}{ }^{-}$ligand.

\subsubsection{Synthesis of $\mathrm{Ph}_{2} \mathrm{P}\left(\mathrm{NSiMe}_{3}\right)_{2} \mathrm{Li}(22)$}

Compound $\mathrm{Ph}_{2} \mathrm{P}\left(\mathrm{NSiMe}_{3}\right)_{2} \mathrm{H}$ (21) was prepared by a previously reported method. ${ }^{134}$ Treatment of iminophosphonamide with $\mathrm{MeLi}$ or $n \mathrm{BuLi}$ yielded the lithium salt of iminophosphonamide $\mathrm{L}^{2} \mathrm{Li}(\mathbf{2 2})\left(\mathrm{L}^{2}=\mathrm{Ph}_{2} \mathrm{P}\left(\mathrm{NSiMe}_{3}\right)_{2}\right)$ in high yield (Scheme 21). ${ }^{135}$ The ${ }^{1} \mathrm{H}$ NMR spectrum of 22 exhibits one singlet at $\delta 0.12 \mathrm{ppm}$ which can be atributed to $\mathrm{SiMe}_{3}$ 
groups while the aromatic protons appear between $\delta 6.98$ and $7.80 \mathrm{ppm}$. 22 shows a resonance at $\delta 7.4 \mathrm{ppm}$ in its ${ }^{31} \mathrm{P}$ NMR spectrum.

\section{Scheme 21}

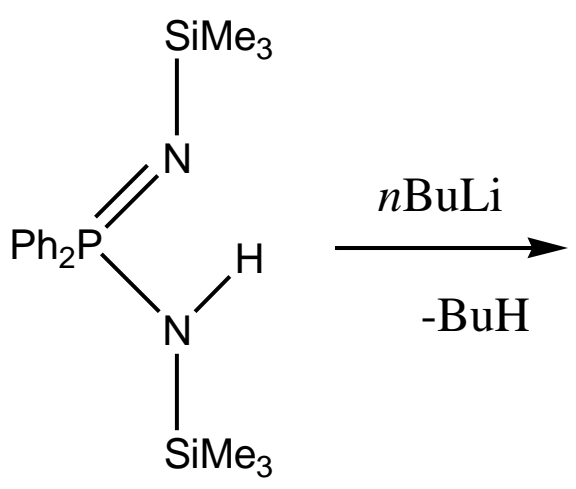

21

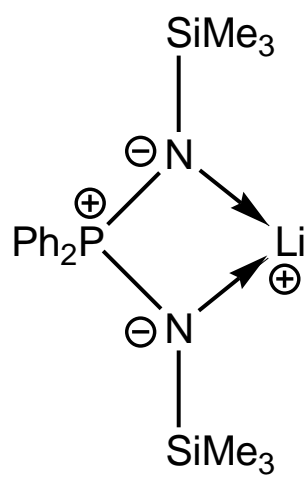

$\mathrm{L}^{2} \mathrm{Li}$

\subsubsection{Reaction of $L^{2} \mathrm{Li}$ with $\mathrm{RAlCl}_{2}$ : Synthesis of $\mathrm{Ph} \mathrm{h}_{2} \mathrm{P}\left(\mathrm{NSiMe}_{3}\right)_{2} \mathrm{AlRCl}(\mathrm{R}=\mathrm{Cl}, 23 ; \mathrm{Me}, 24)$}

Synthesis of $\mathrm{L}^{2} \mathrm{AlCl}_{2}$ (23) (Scheme 22) was accomplished by reacting the lithiated precursor 22 with $\mathrm{AlCl}_{3}$ under elimination of $\mathrm{LiCl}$ in moderate yield. The solution of $\mathrm{AlCl}_{3}$ in toluene was added drop by drop to the solution of 22 in a 1:1 stoichiometric ratio in toluene, and stirred at $25^{\circ} \mathrm{C}$ for $14 \mathrm{~h}$ which yields the colorless complex 23. In a similar route complex 24 was prepared by slow addition of $\mathrm{AlMeCl}_{2}(1.0 \mathrm{M}$ in $n$-hexane) to the toluene solution of 22, and stirring at room temperature for $14 \mathrm{~h}$. Compounds $\mathbf{2 3}$ and $\mathbf{2 4}$ are soluble in common organic solvents such as toluene, THF, and $n$-hexane, and they are stable in the solid state at room temperature for several months under an inert atmosphere. 23 is easily hydrolyzed on exposure to air as indicated by a color change from colorless to a light yellow oily solid, and we were not able to measure elemental analysis of 23 due to its sensitivity. The ${ }^{31} \mathrm{P}$ NMR spectra of $\mathbf{2 3}$ and $\mathbf{2 4}$ exhibit downfield shifts when compared with those of complex 22 ( $\delta$ $37.8 \mathrm{ppm}$ for $\mathbf{2 3}, 33.2 \mathrm{ppm}$ for $\mathbf{2 4}, 7.4 \mathrm{ppm}$ for $\mathbf{2 2}$ ). The ${ }^{1} \mathrm{H}$ NMR of $\mathbf{2 4}$ exhibits a single 
resonance $(\delta 0.04 \mathrm{ppm})$ which can be assigned to $\mathrm{Al}-\mathrm{Me}$. The 18 protons of $\mathrm{SiMe}_{3}$ resonate as a singlet at $\delta-0.03 \mathrm{ppm}$ and the aromatic protons of $\mathrm{Ph}$ are shown at $\delta 7.46-7.79 \mathrm{ppm}$.

\section{Scheme 22}
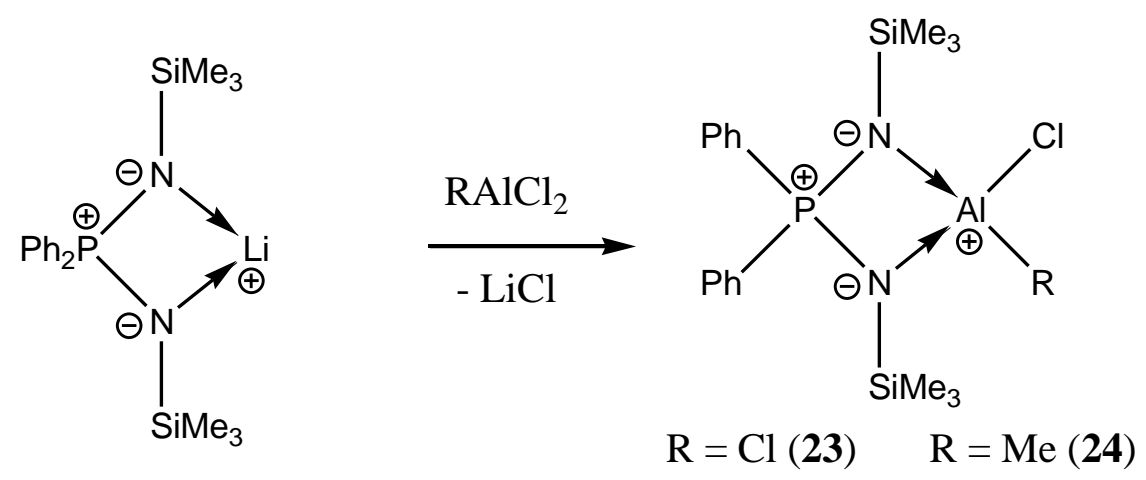

Complexes 23 and $\mathbf{2 4}$ were characterized further by X-ray crystallography, and the molecular structures are presented in Figures 21 and 22. Compound $\left[\mathrm{Ph}_{2} \mathrm{P}\left(\mathrm{NSiMe}_{3}\right)_{2} \mathrm{AlCl}_{2}\right]$ (23) crystallizes in the triclinic space group $P \overline{1}$ with two molecules in the asymmetric unit whereas $\left[\mathrm{Ph}_{2} \mathrm{P}(\mathrm{NSiMe})_{2} \mathrm{AlMeCl}\right](\mathbf{2 4})$ is monomeric in the solid state and crystallizes in the monoclinic space group $P 2_{1} / c$. Colorless crystals of $\mathbf{2 3}$ and $\mathbf{2 4}$ suitable for X-ray structure analysis were grown from toluene and $n$-hexane at $-78^{\circ} \mathrm{C}$ respectively. In both structures the aluminum atoms show a distorted tetrahedral environment, and the metrical parameters associated with the $\mathrm{PN}_{2}$ ligand are quite similar. ${ }^{136}$ All $\mathrm{N}$ atoms bearing $\mathrm{SiMe}_{3}$ groups show a planar arrangement; the Si-N bonds are slightly shorter than the sum of the covalent radii of $1.87 \AA^{137}$, and the P-N distances in the range of 1.614(12)-1.629(16) $\AA$ have been previously rationalized to range between single and double P-N bonds. ${ }^{138}$ However, recent experimental charge density studies proved the shortening mainly to be caused by electrostatic contributions. ${ }^{139}$ In addition to the $\mathrm{P}-\mathrm{N} \sigma$-bonds, there is Coulomb attraction between the positively charged phosphorus atoms and the negatively charged nitrogen atoms, and in return, repulsion between the competing $\mathrm{N}$-atoms across the central P-atom. This 'seesaw' 
effect is most prominent in the structures from the tetra(amino) phosphonium cation, $\left[\mathrm{P}(\mathrm{NHPh})_{4}\right]^{+}$, to the tetra(imino) phosphate trianion, $\left[\mathrm{P}(\mathrm{NPh})_{4}\right]^{3-}$.

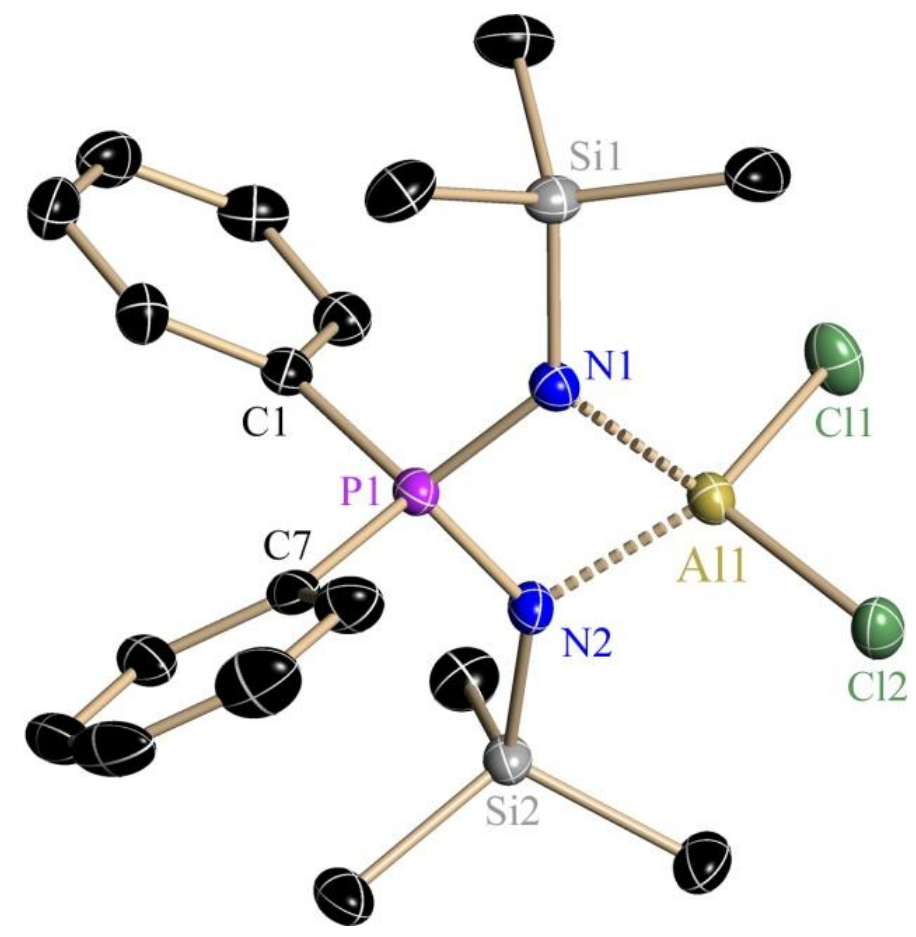

Figure 21. Molecular structure of 23. Anisotropic displacement parameters are drawn at the $50 \%$ probability level. Only one of the two crystal independent molecules is shown. $\mathrm{H}$ atoms are omitted for clarity. Selected bond lengths $\left[\AA \AA\right.$ and angles $\left[^{\circ}\right]$ : Al1-N1 1.880(17), Al1-N2 1.885(17), Si1-N1 1.739(16), Si2-N2 1.747(17), P1-N1 1.629(16), P1-N2 1.623(16), Al1-Cl1 2.132(8), Al1-Cl2 2.130(8), Cl1-Al1-Cl2 109.51(3), Al1-N1-P1 90.59(8), Al1-N2-P1 90.57(8), N1-P1-N2 97.65(8), N1-Al1-N2 81.11(7), C1-P1-C7 107.16(9), Si1-N1-A11 132.34(9), Si1-N1-P1 132.44(10), Si2-N2-Al1 132.11(9), Si2-N2-P1 137.02(10), Cl1-A11-N1 114.04(6), Cl2-Al1-N1 116.42(6), Cl1-Al1-N2 115.83(6), Cl2-Al1-N2 117.67(6).

Despite the diversity of the $\mathrm{P}-\mathrm{N}$ bond lengths, the average $\mathrm{P}-\mathrm{N}$ bond length within the $\mathrm{PN}_{4}$ tetrahedra is very similar $\left.\left(\Sigma\left(d_{\mathrm{P}-\mathrm{N}}\right)\right\} / 4=1.62(1) \AA\right) .{ }^{140} \mathrm{On}$ this basis we state that there is no $\mathrm{P}=\mathrm{N}$ double bonding, and hence no hypervalent phosphorus present in the iminophosphonamide ligands presented in this paper. ${ }^{141}$ 
The Al-Cl bond lengths in compound $\mathbf{2 3}$ are shorter than that of compound $\mathbf{2 4}$, while the ligand bite (N1-Al1-N2) in $23\left(\right.$ av $\left.81.09^{\circ}\right)$ is slightly bigger than that in $\mathbf{2 4}\left(80.04(5)^{\circ}\right)$. The Al-Cl distances in $\mathbf{2 3}$ (av 2.129 $\AA$ ) are quite similar to those observed in the mono 1-aza-allyl complex $\left[\mathrm{N}\left(\mathrm{SiMe}_{3}\right) \mathrm{C}(\mathrm{Ph}) \mathrm{C}\left(\mathrm{SiMe}_{3}\right)_{2}\right] \mathrm{AlCl}_{2}$ (av 2.071 $\AA$ ) but the core angle is significantly different due to non equivalent chelating backbone. ${ }^{142}$

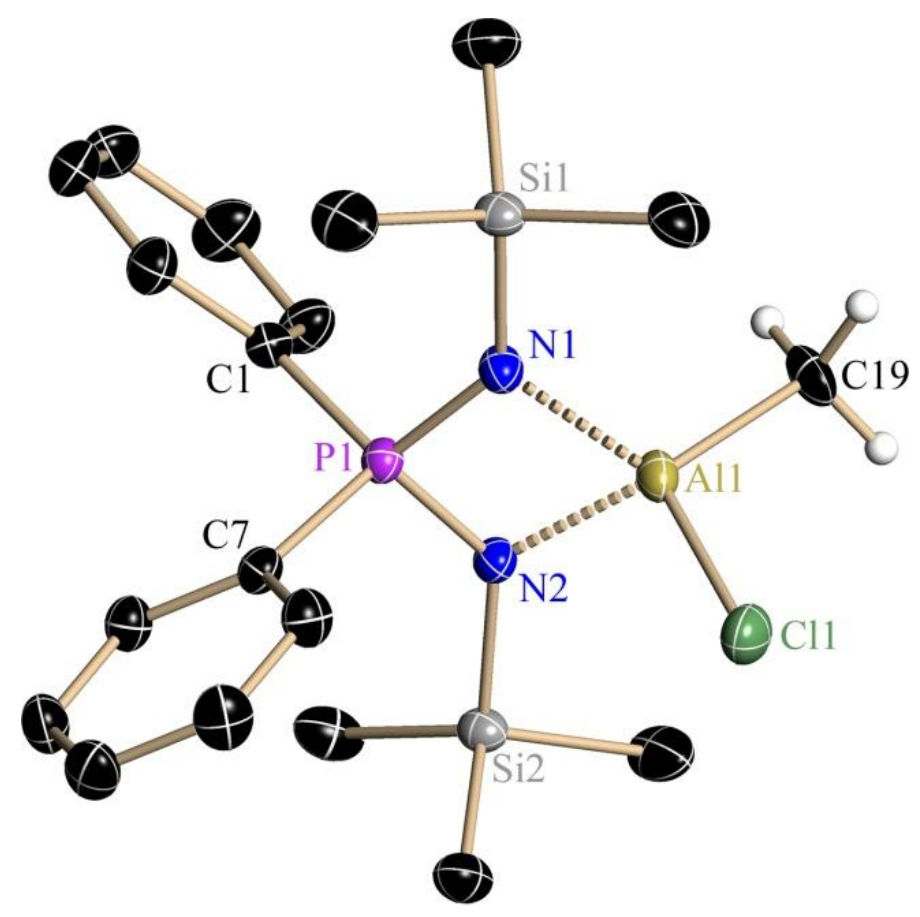

Figure 22: Molecular structure of 24. Anisotropic displacement parameters are drawn at the $50 \%$ probability level. $\mathrm{H}$ atoms (except for those of C19) and half toluene solvent molecule are omitted for clarity. Selected bond lengths $\left[\AA \AA\right.$ ] and angles $\left[{ }^{\circ}\right]$ : Al1-N1 1.899(13), Al1-N2 1.909(13), Si1-N1 1.736(12), Si2-N2 1.733(12), P1-N1 1.614(12), P1-N2 1.617(12), Al1-Cl1 2.155(6), Al1-C19 1.947(15), Cl1-Al1-C19 111.89(6), Al1-N1-P1 90.89(6), Al1-N2-P1 90.41(6), N1-P1-N2 98.56(6), N1-Al1-N2 80.04(5), C1-P1-C7 106.846(7), Si1-N1-Al1 131.52(7), Si1-N1-P1 136.69(8), Si2-N2-Al1 128.83(7), Si2-N2-P1 134.17(8), Cl1-Al1-N1 110.81(4), C19-Al1-N1 120.92(7), Cl1-Al1-N2 109.69(4), C19-Al1-N2 119.69(6). 


\subsubsection{Reaction of $\mathrm{L}^{2} \mathrm{H}$ with $\mathrm{AlH}_{3} \cdot \mathrm{NMe}_{3}$ : Synthesis of $\left[\mathrm{Ph}_{2} \mathrm{P}\left(\mathrm{NSiMe}_{3}\right)_{2}\right]_{2} \mathrm{AlH}(25)$}

Organoaluminum hydrides of low aggregation have proved to be effective reagents for preparing chalcogenide compounds with elemental chalcogens or organochalcogenides, ${ }^{143}$ such as $\mathrm{LAl}(\mathrm{SeH})_{2}, \operatorname{LAl}(\mathrm{SeH}) \mathrm{Se}(\mathrm{SeH}) \mathrm{AlL}\left(\mathrm{L}=\mathrm{HC}(\mathrm{CMeNAr})_{2}, \mathrm{Ar}=2,6-i \mathrm{Pr}_{2} \mathrm{C}_{6} \mathrm{H}_{3}\right),{ }^{144}$ $\mathrm{LAl}(\mathrm{SH})_{2}\left(\mathrm{~L}=\mathrm{HC}(\mathrm{CMeNAr})_{2}, \mathrm{Ar}=2,6-i \mathrm{Pr}_{2} \mathrm{C}_{6} \mathrm{H}_{3}\right),{ }^{145} \mathrm{Al}_{4} \mathrm{Se}_{5}(\mathrm{H})_{2}\left(\mathrm{NMe}_{3}\right)_{4} \cdot{ }^{146}$ As an extension of this type of reaction, we explored iminophosphonamide 21 to react with $\mathrm{AlH}_{3} \cdot \mathrm{NMe}_{3}$ to afford an aluminum monohydride $\left[\mathrm{Ph}_{2} \mathrm{P}\left(\mathrm{NSiMe}_{3}\right)_{2}\right]_{2} \mathrm{AlH}(\mathbf{2 5})$ under elimination of hydrogen.

Reaction of iminophosphonamide 21 with $\mathrm{AlH}_{3} \cdot \mathrm{NMe}_{3}$ in 2:1 stoichiometric ratio in $n$ hexane/THF at $-78 \quad{ }^{\circ} \mathrm{C}$ afforded the iminophosphonamide aluminum complex $\left[\mathrm{Ph}_{2} \mathrm{P}\left(\mathrm{NSiMe}_{3}\right)_{2}\right]_{2} \mathrm{AlH}$ (25) in moderate yield (Scheme 23 ). The ${ }^{1} \mathrm{H}$ NMR spectrum of 25 exhibits a broad singlet at $\delta 5.1 \mathrm{ppm}$ assigned to the $\mathrm{AlH}$ and two singlets at $\delta-0.22$ and -0.13 ppm, which can be assigned to the 36 protons of the $\mathrm{SiMe}_{3}$ units. The presence of two non equivalent $\mathrm{SiMe}_{3}$ groups indicates a restricted fluctionality of these groups at room temperature. In the IR spectrum one weak absorption for the AlH stretching frequency is observed at $1853 \mathrm{~cm}^{-1} .{ }^{31} \mathrm{P}$ NMR spectrum of 25 exhibits two single resonances at $\delta 29.2$ and $34.6 \mathrm{ppm} .25$ is stable in the solid state under an inert atmosphere and is slowly oxidized and hydrolyzed on exposure to air.

\section{Scheme 23}
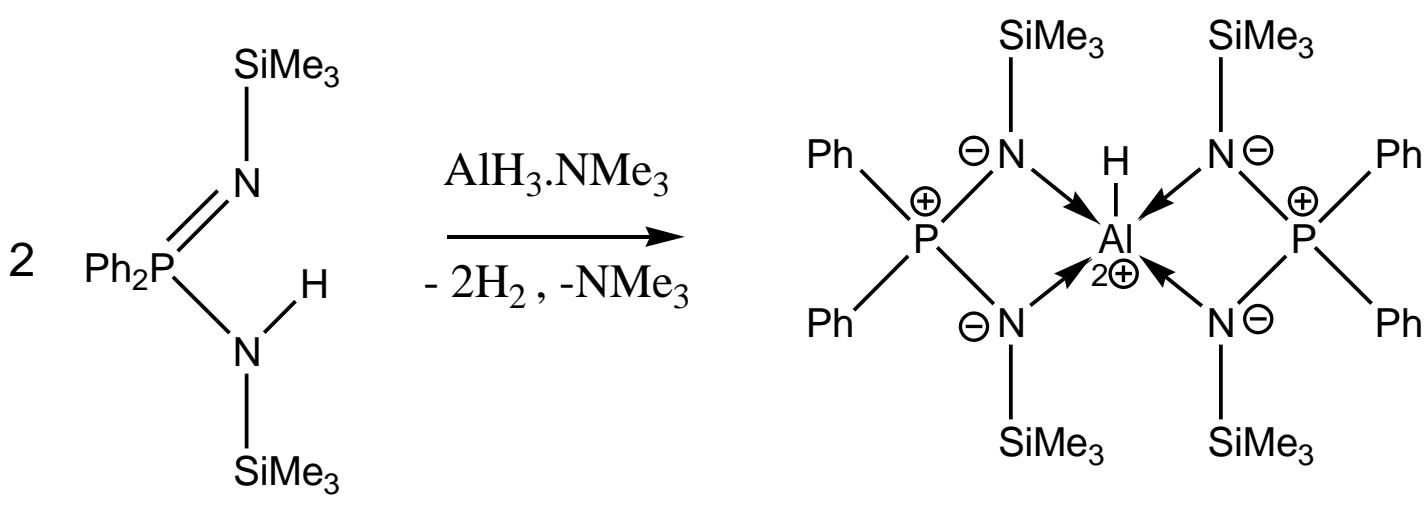
Complex 25 was characterrized further by X-ray crystallography and the molecular structure is presented in Figure 23. The X-ray structure reveals that in $\mathbf{2 5}$ the aluminum is five coordinate and in a distorted trigonal bipyramidal geometry with $\mathrm{N} 1$ and $\mathrm{N} 4$ in axial positions and $\mathrm{N} 2, \mathrm{~N} 3$, and $\mathrm{H}$ in the equatorial plane. The N1-A11-N4 axis is almost linear [N1-Al1-N4 $175.80(5)^{\circ}$ ] in which the Al-N bond lengths of 2.08(13) $\AA$ for Al-N1 and 2.100(13) for Al1-N4 are almost the same. The equatorial Al1-N2 and Al1-N3 having almost

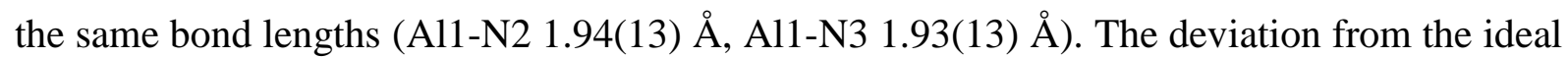
trigonal-bipyramidal geometry can be described by an angle of $73.94(26)^{\circ}$ between the leastsquares plane of N1, Al, N4, H and the equatorial plane. Clearly, the deviation from ideal trigonal-bypyramidal geometry arises from the steric requirements of the two chelating ligands. The axial Al-N bond lengths are in good agreement with those which are observed in similar five coordinate aluminum complexes ${ }^{147}$ where Al-N bond lengths are found in the

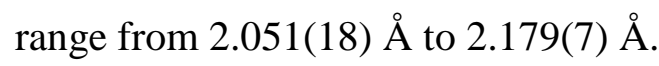

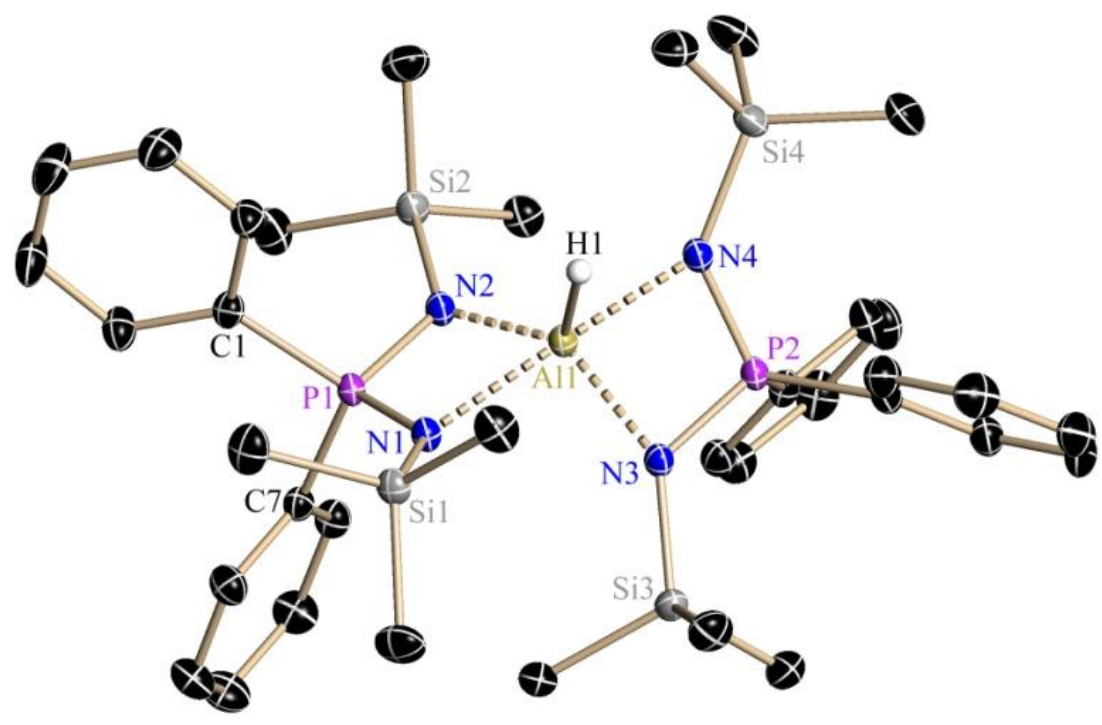

Figure 23. Molecular structure of 25. Anisotropic displacement parameters are drawn at the $50 \%$ probability level. $\mathrm{H}$ atoms (except for those of Al1) and one THF solvent molecule are omitted for clarity. Selected bond lengths $[\AA]$ and angles $\left[^{\circ}\right]$ : Al1-N1 2.080(13), A11-N2 1.947(13), Si1-N1 1.7252(13), Si2-N2 1.7381(13), P1-N1 1.5923(13), P1-N2 1.6162(12), 
Al1-N3 1.939(13), Al1-N4 2.100(13), N3-A11-N4 75.66 (5), Al1-N1-P1 89.23(6), Al1-N2-P1

93.90(6), N1-P1-N2 101.10(6), N1-Al1-N2 75.75(5), C1-P1-C7 106.58(7), Si1-N1-Al1

133.46(7), Si1-N1-P1 133.13(8), Si2-N2-Al1 135.69(7), Si2-N2-P1 128.08(8), N3-A11-N1

102.38(5), N4-Al1-N1 175.80(5), N3-Al1-N2 110.34(6), N4-Al1-N2 101.33(5).

\subsubsection{Reaction of $\mathrm{L}^{2} \mathrm{H}$ with $\mathrm{AlEt}_{3}$ and $\left[\mathrm{Al}\left(\mathrm{NMe}_{2}\right)_{3}\right]_{2}$ : Synthesis of $\mathrm{Ph}_{2} \mathrm{P}\left(\mathrm{NSiMe}_{3}\right)_{2} \mathrm{AlEt}_{2}(26)$} and $\mathrm{Ph}_{2} \mathrm{P}\left(\mathrm{NSiMe}_{3}\right)_{2} \mathrm{Al}\left(\mathrm{NMe}_{2}\right)_{2}(27)$

Compound 26 was prepared as a white crystalline solid from the reaction of iminophosphonamide 21 with $\mathrm{AlEt}_{3}$ in $n$-hexane at $-78^{\circ} \mathrm{C}$. Reaction of 21 with $\left[\mathrm{Al}\left(\mathrm{NMe}_{2}\right)_{3}\right]_{2}$ in $n$-hexane at reflux temperature for $6 \mathrm{~h}$ afforded the aluminum amide complex 27 (Scheme 24). Both compounds are soluble in common organic solvents such as $n$-hexane, toluene, and tetrahydrofuran. 27 is stable in the solid state under an inert atmosphere and is slowly hydrolyzed on exposure to air whereas $\mathbf{2 6}$ is not stable and very sensitive to air. Therefore we were not able to determine the elemental analysis. ${ }^{31} \mathrm{P}$ NMR spectra of 26 and 27 exhibit single resonances at $\delta 30.3$ and $28.6 \mathrm{ppm}$, respectively. In both compounds the ${ }^{1} \mathrm{H}$ NMR and

${ }^{29} \mathrm{Si}$ NMR spectra exhibit only one singlet for the $\mathrm{SiMe}_{3}$ groups. In compound 27 the 12 protons correspond to $\mathrm{NMe}_{2}$ and resonate at $\delta 3.06 \mathrm{ppm}$ while the aromatic protons appear between $\delta 7.03$ and $7.83 \mathrm{ppm}$.

\section{Scheme 24}<smiles>CSN=PN(C)P</smiles>

21

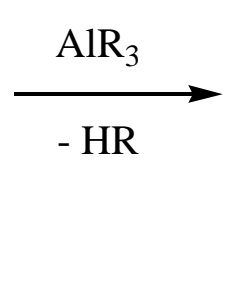

$$
\mathrm{R}=\mathrm{Et}(\mathbf{2 6})
$$

$$
\mathrm{R}=\mathrm{NMe}_{2} \text { (27) }
$$


Colorless compound 27 crystallizes in the monoclinic space group $P 2_{1} / n$, with one monomer in the asymmetric unit from $n$-hexane at $-78^{\circ} \mathrm{C}$. The coordination polyhedron around the aluminum atom features a distorted tetrahedral environment and the metrical parameters associated with the $\mathrm{PN}_{2}$ ligand are quite similar to those of $\mathbf{2 2}$ and $\mathbf{2 3}$. The $\mathrm{Al}-\mathrm{N} 3$ and Al-N4 bond distances are comparable to those reported in structurally characterized Albound terminal $\mathrm{NMe}_{2}$ groups. ${ }^{148}$ The Al-N1 and Al-N2 bond lengths (1.937(12)-1.950(12) $\AA$ ) are longer than the Al-N3 and Al-N4 distances (1.790(13)-1.795(12) $\AA$ ), due to the electronically delocalized $\mathrm{PN}_{2}$ ligand.

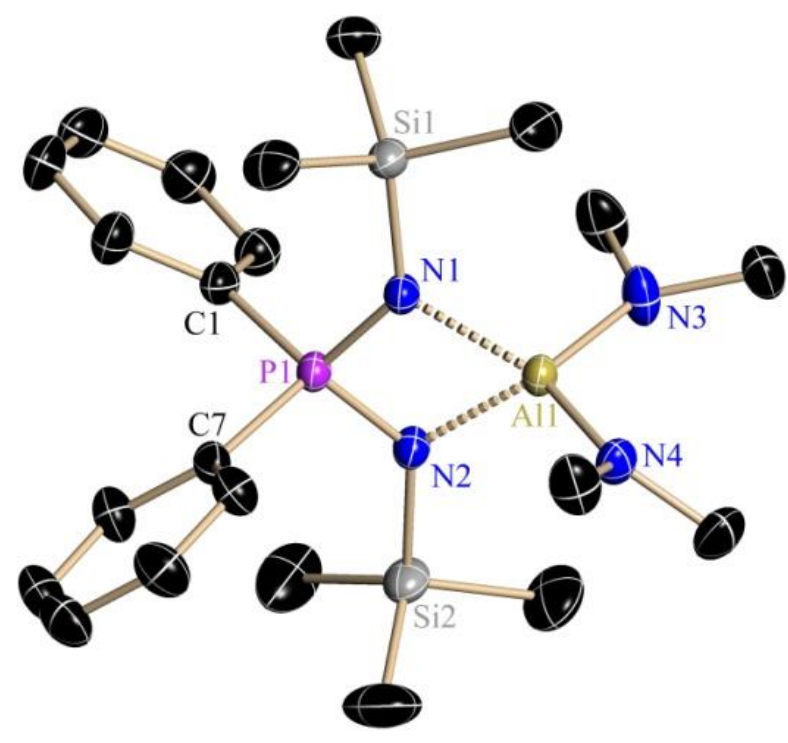

Figure 24. Molecular structure of 27. Anisotropic displacement parameters are drawn at the $50 \%$ probability level. $\mathrm{H}$ atoms are omitted for clarity. Selected bond lengths $[\AA]$ and angles $\left[^{\circ}\right]:$ Al1-N1 1.937(12), Al1-N2 1.950(12), Si1-N1 1.727(12), Si2-N2 1.728(12), P1-N1 1.614(11), P1-N2 1.606(12), Al1-N3 1.795(12), Al1-N4 1.790(13), N3-Al1-N4 111.61(6), Al1-N1-P1 91.38(6), Al1-N2-P1 91.14(6), N1-P1-N2 99.15(6), N1-Al1-N2 78.21(5), C1-P1C7 104.23(7), Si1-N1-Al1 131.04(6), Si1-N1-P1 133.52(7), Si2-N2-Al1 130.33(6), Si2-N2P1 133.57(7), N3-Al1-N1 113.12(6), N4-Al1-N1 118.87(6), N3-Al1-N2 119.33(6), N4-Al1N2 112.27(6). 


\subsubsection{Structural Comparison of $\mathrm{LAlCl}_{2}$ (23), LAlMeCl (24), $\mathrm{L}_{2} \mathrm{AlH}(25)$, and $\mathrm{LAl}\left(\mathrm{NMe}_{2}\right)_{2}$} (27)

The superposition of the $\mathrm{PN}_{2} \mathrm{Al}$ four-membered rings in the four structures in Figure 25 reveals that not only this motif remains widely unchanged but even the phenyl groups adopt the same orientation. Also the remaining substituents at aluminum stay almost in place. Remarkably, only one of the two $\mathrm{Me}_{3} \mathrm{Si}$ groups responds to the various steric requirements of those two exocyclic substituents. Switching one of the chlorine substituents in $\mathbf{2 3}$ to a methyl group in $\mathbf{2 4}$ leaves the angle sum at the nitrogen atom virtually unchanged (359.7 vs $359.1^{\circ}$ ) and the silyl atom almost shares the plane with the $\mathrm{PN}_{2} \mathrm{Al}$ four-membered ring. Only the second iminophosphonamide ligand in $\mathbf{2 5}$ and the two dimethylamino groups in $\mathbf{2 7}$ remove that silyl group from the plane, indicated by an angle sum of only 356.16 and $355.94^{\circ}$, respectively.

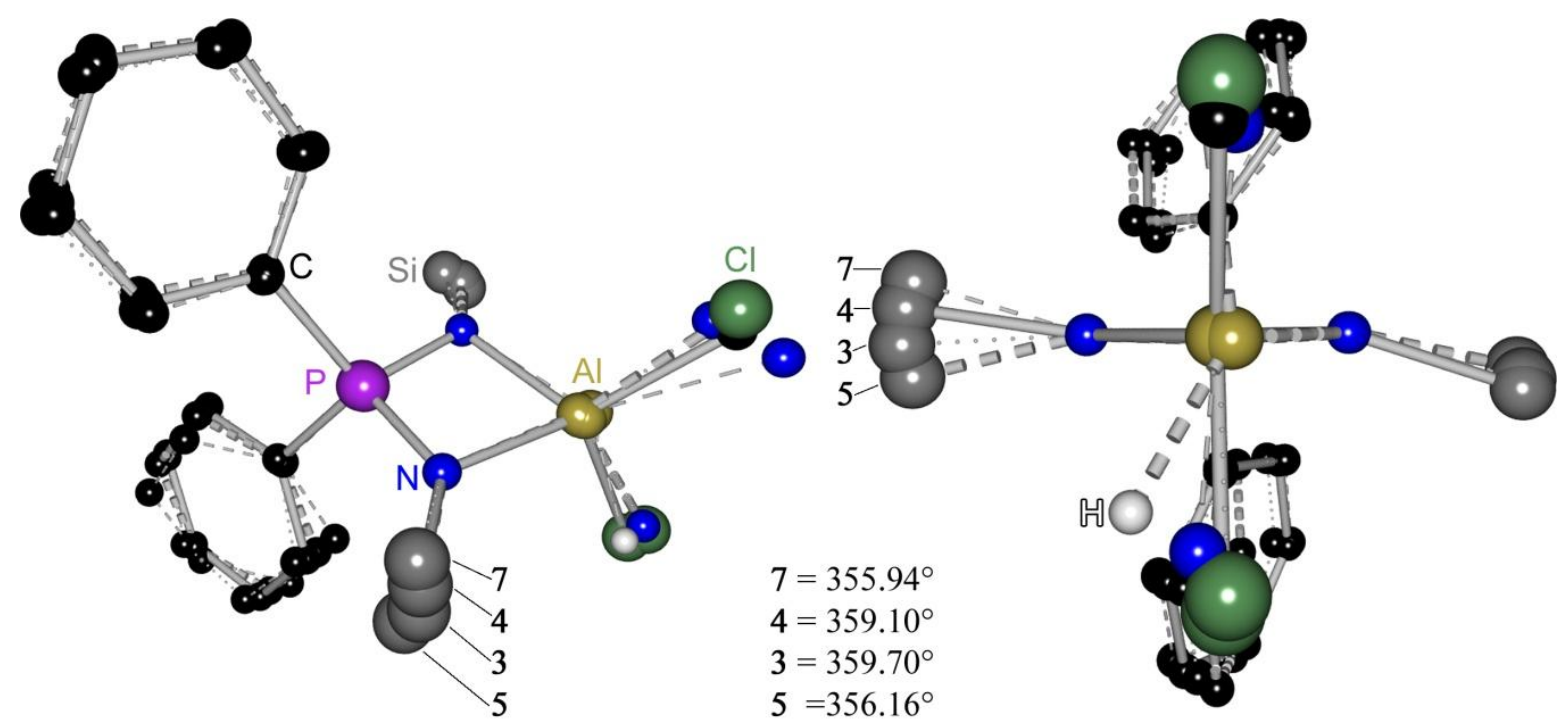

Figure 25. Superposition of $\mathbf{2 3}, \mathbf{2 4}, \mathbf{2 5}$, and 27, depicting the response of the trimethylsilyl group at $\mathrm{N} 1$ to the bulk of the two other substituents at the aluminum atom. 


\section{Summary and Outlook}

\subsection{Summary}

Organometallic molecules with useful functionalities have gained tremendous attention. Substitution of functionalities leads to the synthesis of a variety of other new derivatives, and condensation in a controlled manner with suitable metal synthons affords a route to homoand heterobimetallic complexes which are mostly useful as catalysts.

The first part of the thesis deals with the synthesis of bismuth amide complex and its reaction with compounds containing unsaturated $\mathrm{C}-\mathrm{O}, \mathrm{C}-\mathrm{C}$, and $\mathrm{C}-\mathrm{N}$ bonds. The main motivation for the research in the field of the bismuth chemistry is, without any doubt, the role of bismuth compounds in catalysis and due to their non toxicity in pharmacology. $\mathrm{L}^{1} \mathrm{BiNMe}_{2}$ (1) was prepared by the reaction of 1,8-bis[(trimethylsilyl)amino]naphthalene with $\mathrm{Bi}\left(\mathrm{NMe}_{2}\right)_{3}$. To investigate the reactivity of bismuth-nitrogen bond toward carbon-oxygen bond we treated 1 with aldehyde and keton. The reaction of 1 with 2-benzoylpyridine and 3pyridinecarboxaldehyde proceeds smoothly at room temperature to give addition products in which 2-benzoylpyridine and 3-pyridinecarboxaldehyde insert into the $\mathrm{Bi}-\mathrm{N}$ bond of $\mathbf{1}$ under formation of $\mathbf{2}$ and $\mathbf{3}$, respectively.

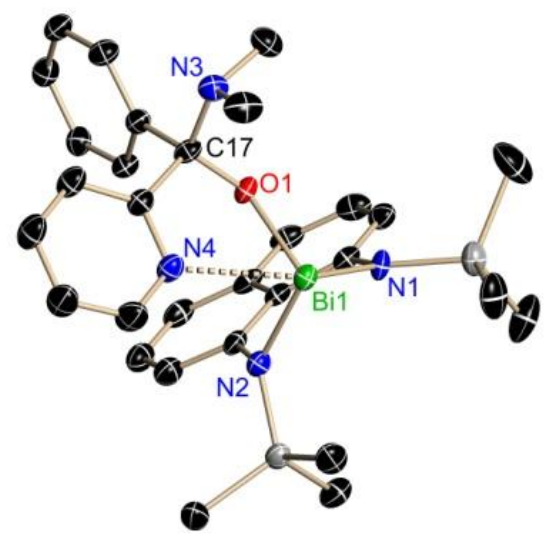

Molecular Structure of 2

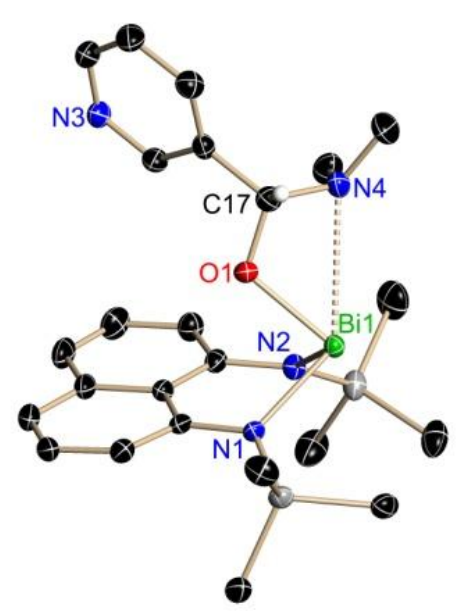

Molecular Structure of 3 
To extend those findings to carbon-carbon bonds we reacted $\mathbf{1}$ with alkene and alkine. Compounds 4 and 5 were obtained by reaction of 1 with 2-methyl-2-propenenitrile and diethyl acetylene dicarboxylate, respectively. During the formation of $\mathbf{5}$ the exchange of one of the OEt groups by a $\mathrm{NMe}_{2}$ substituent occurred.

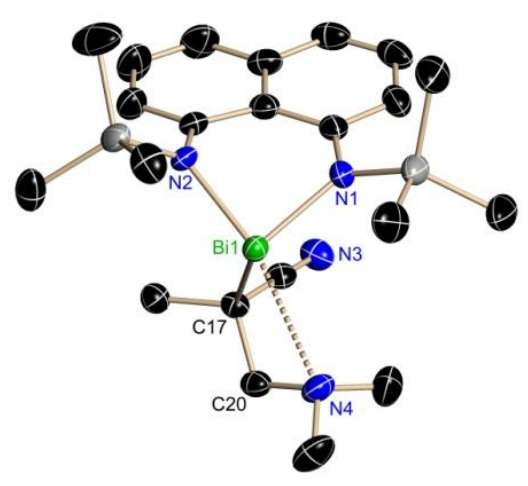

Molecular Structure of 4

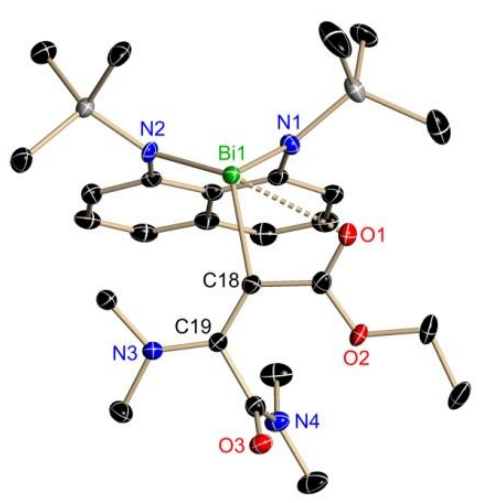

Molecular Structure of 5

Compounds 6 and 7 are the products of bismuth-nitrogen bond insertion to carbonnitrogen bonds. Reaction of $\mathbf{1}$ with diisopropylcarbodiimide and phenylisocyanate results in the formation of $\mathbf{6}$ and 7, indicating that carbodiimide and isocyanate molecules are inserted into the Bi-N bond, respectively.

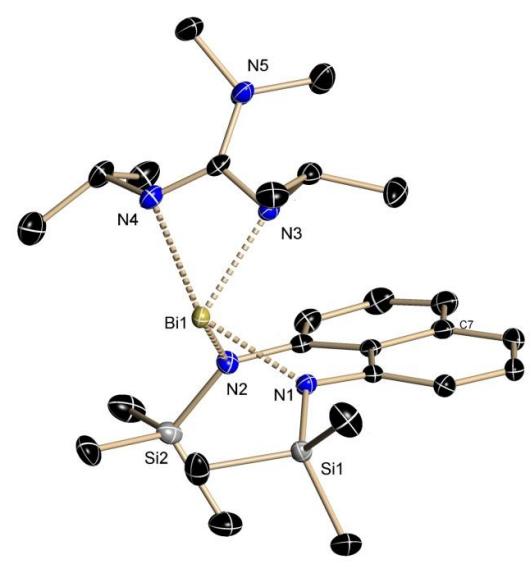

Molecular Structure of 6

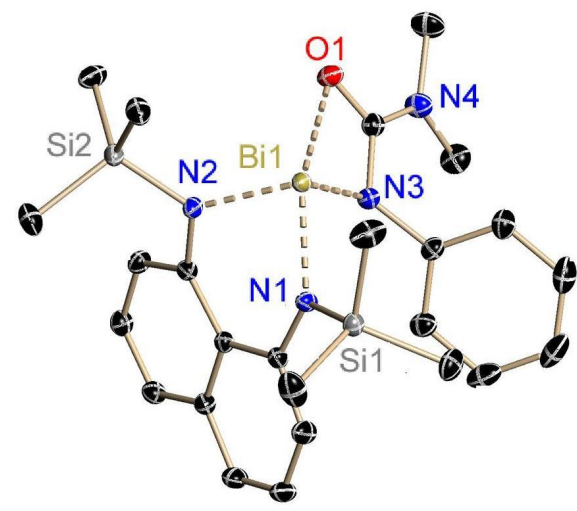

Molecular Structure of 7 
Due to the basic character of the $\mathrm{NMe}_{2}$ group, compound 1 was utilized to prepare a series of heterobimetallic oxides. The second part of the thesis describes the efforts to synthesize oxygen-bridged heterobimetallic complexes of bismuth with main group and transition metals which are difficult to achieve by other methods. The bismuthamide (1) complex acts as a building block for the preparation of the first structurally characterized oxygen bridged heterobimetallic complexes of groups 4, 13 and 14 metals. Thus, the reaction of $\mathrm{L}^{1} \mathrm{BiNMe}_{2}$ (1) with $\mathrm{LM}(\mathrm{Me})(\mathrm{OH})$ and $\mathrm{LGe}(\mathrm{OH})\left(\mathrm{M}=\mathrm{Al}, \mathrm{Ga}, \mathrm{L}=\mathrm{CH}((\mathrm{CMe}) \mathrm{NAr})_{2}, \mathrm{Ar}=\right.$ 2,6-i $\left.\operatorname{Pr}_{2} \mathrm{C}_{6} \mathrm{H}_{3}\right)$, provides the complexes $\mathrm{L}^{1} \mathrm{Bi}(\mu-\mathrm{O}) \mathrm{MMeL}\left(\mathrm{M}=\mathrm{Al} \mathbf{8}\right.$; Ga, 9) and $\mathrm{L}^{1} \mathrm{Bi}(\mu$ O)GeL (10).

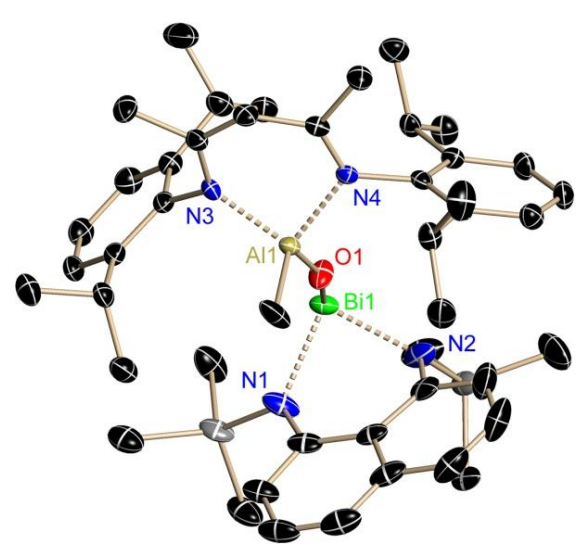

Molecular Structure of 8

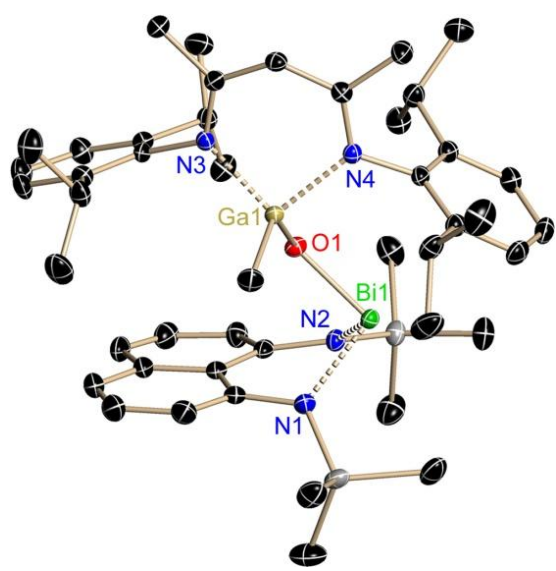

Molecular Structure of 9

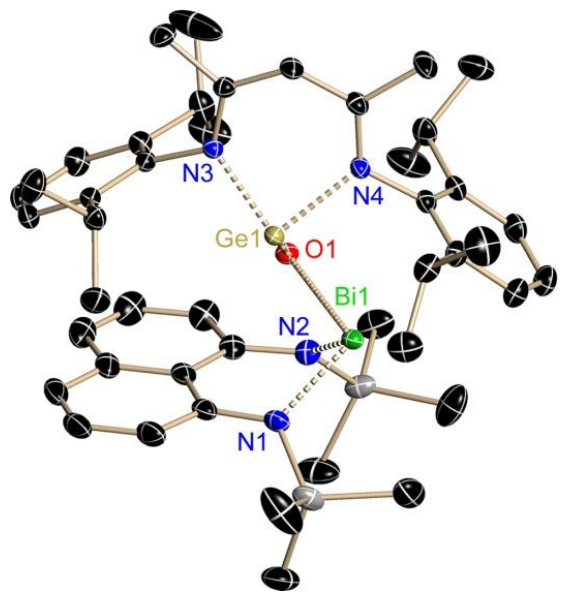

Molecular Structure of 10 
The study of the half-metallocenes of zirconium and hafnium bearing terminal methyl and chloride groups is limited because of their thermal and kinetic instability. A series of heterobimetallic complexes of half-metallocenes bearing terminal methyl and chloride groups have been prepared. The transition metal hydroxides $\mathrm{Cp}^{*}{ }_{2} \mathrm{ZrMe}(\mathrm{OH})$ and $\mathrm{Cp} *{ }_{2} \mathrm{HfCl}(\mathrm{OH})$ react with 1 to generate the corresponding complexes $\mathrm{L}^{1} \mathrm{Bi}(\mu-\mathrm{O}) \mathrm{ZrMeCp}^{*}{ }_{2}(\mathbf{1 1})$ and $\mathrm{L}^{1} \mathrm{Bi}(\mu$ O)HfClCp* ${ }_{2}$ (12) under elimination of $\mathrm{HNMe}_{2}$. X-ray structural analysis reveals the presence of bent $\mathrm{Bi}(\mu-\mathrm{O}) \mathrm{Zr}$ and $\mathrm{Bi}(\mu-\mathrm{O}) \mathrm{Hf}$ cores.

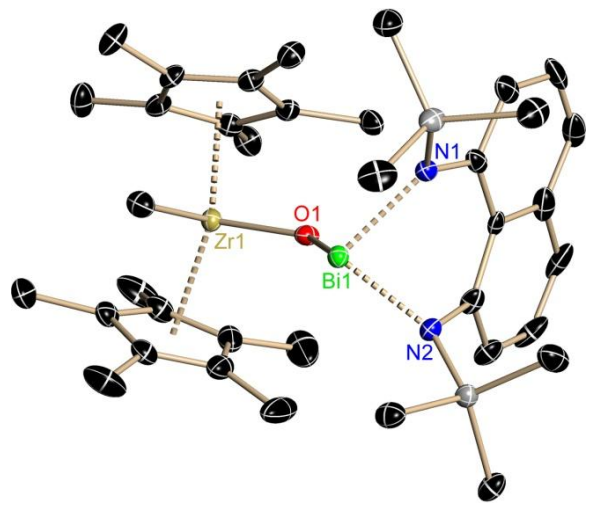

Molecular Structure of 11

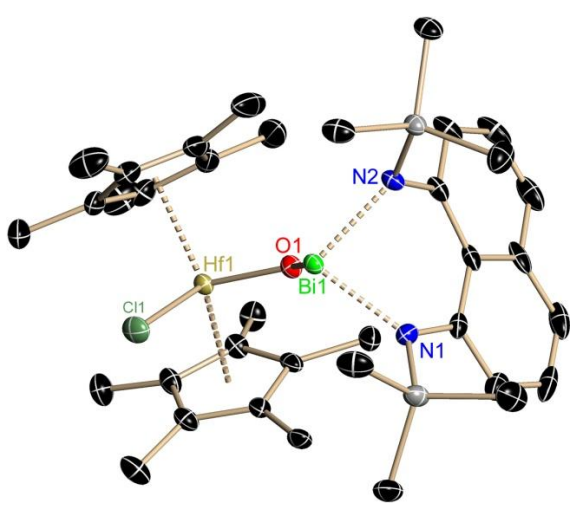

Molecular Structure of 12

From the point of view of the applications in catalysis and organic synthesis the organobismuth(III) complexes play a very important role. Under given reaction conditions the amide group can be selectively substituted or replaced by another similar or different functional group. Thus, the reaction of $\mathrm{L}^{1} \mathrm{BiNMe}_{2}$ (1) with $\mathrm{ClSiMe}_{3}$ smoothly yields the corresponding chloride $\mathrm{L}^{1} \mathrm{BiCl}$ (13).

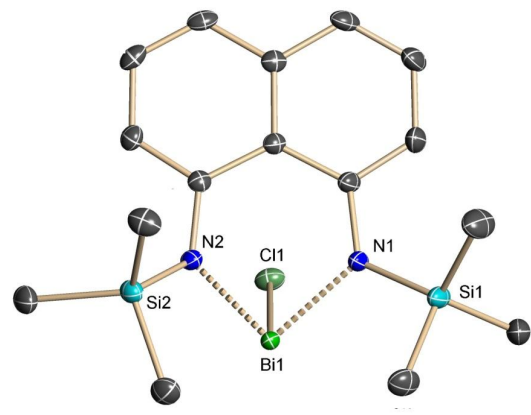

Molecular Structure of 13 
Treatment of 1 with $\mathrm{HCCPh}, \mathrm{Cp} * \mathrm{H}, \mathrm{AlMe}_{3}, \mathrm{PhOH}$ and $\mathrm{NH}_{3}$ resulted in the formation of the organobismuth(III) complexes $\mathrm{L}^{1} \mathrm{BiCCPh}(\mathbf{1 4}), \mathrm{L}^{1} \mathrm{BiCp} *(\mathbf{1 5}), \mathrm{L}^{1} \mathrm{BiMe}(\mathbf{1 6}), \mathrm{L}^{1} \mathrm{BiOPh}(\mathbf{1 7})$ and $\mathrm{L}^{1} \mathrm{BiNH}_{2}$ respectively. The molecular structures of $\mathbf{1 4}, \mathbf{1 5}$ and $\mathbf{1 6}$ have been determined by X-ray structure analysis. Compound $\mathbf{1 5}$ is an example of a half-sandwich bismuth(III) complex with bonding to $\mathrm{Cp}^{*}$ in an $\eta^{1}$ or $\eta^{3}$ chelating mode. LBiMe (16) can be synthesized by slow addition of $\mathrm{AlMe}_{3}$ in $n$-hexane to the $n$-hexane solution of $\mathbf{1}$.

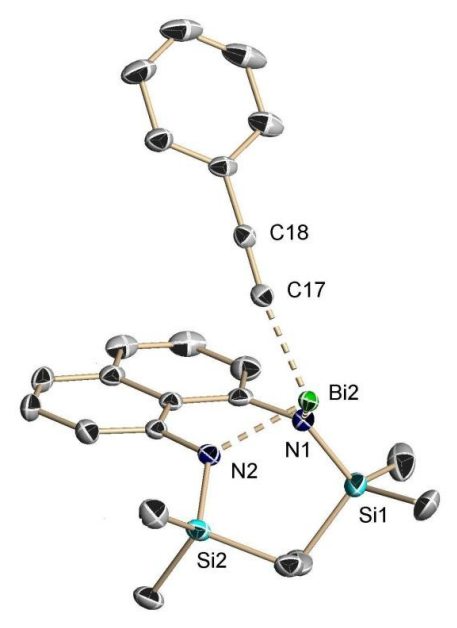

Molecular Structure of 14

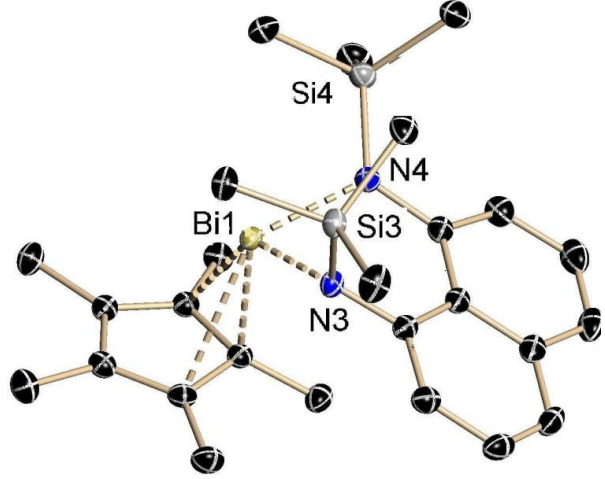

Molecular Structure of 15

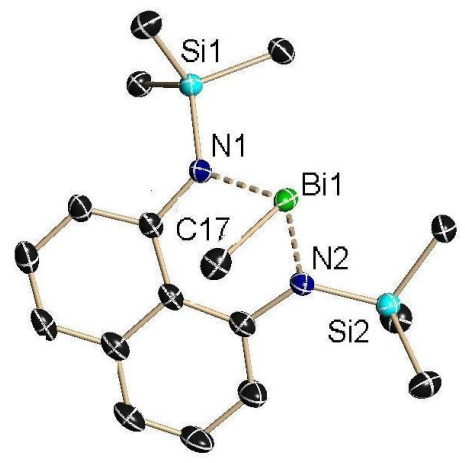

Molecular Structure of 16

Reaction of 1 with elemental sulfur and $\mathrm{PhSiH}_{3}$ affords a bimetallic derivative of composition $\left(\mathrm{L}^{1} \mathrm{Bi}\right)_{2} \mathrm{~S}(\mathbf{1 9})$ with a bent $\mathrm{Bi}(\mu-\mathrm{S}) \mathrm{Bi}$ core and a low valent dibismuthine $\left(\mathrm{L}^{1} \mathrm{Bi}\right)_{2}$ (20) complex, respectively. 


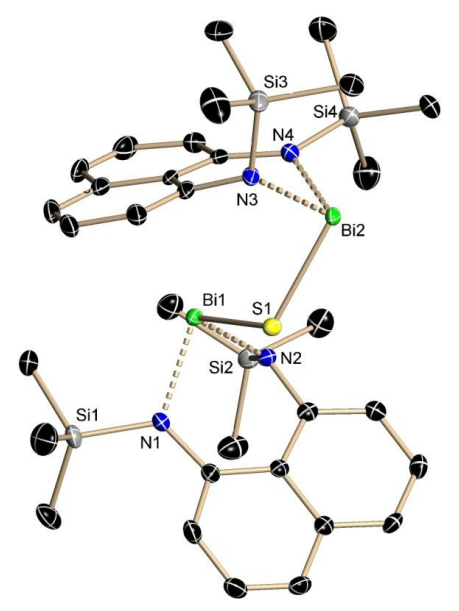

Molecular Structure of 19

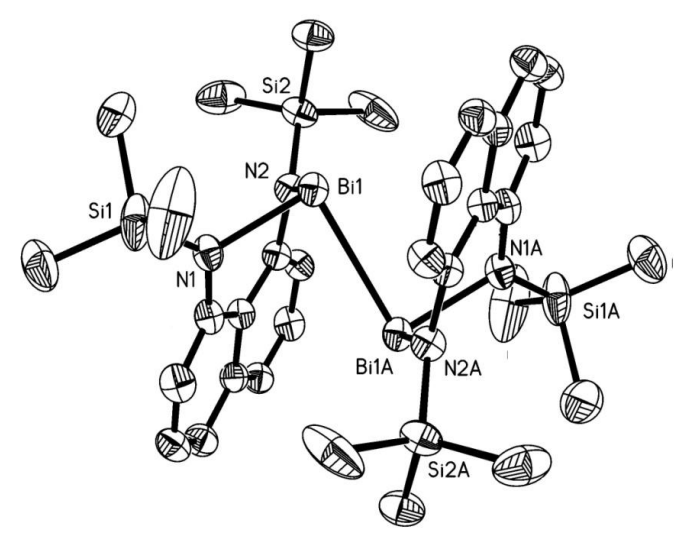

Molecular Structure of 20

The last part of the thesis deals with the synthesis of four-membered aluminum rings bearing halide, methyl, and hydride substituents. Aluminum hydrides, alkylates, and halides are involved in most of aluminum containing reactions and they are extraordinary important for aluminum chemistry

Iminophosphonamide aluminum dichloride and methylchloride $\mathrm{L}^{2} \mathrm{AlCl}_{2}$ (23) and $\mathrm{L}^{2} \mathrm{AlMeCl}(\mathbf{2 4})\left(\mathrm{L}^{2}=\mathrm{Ph}_{2} \mathrm{P}\left(\mathrm{NSiMe}_{3}\right)_{2}\right)$ were easily obtained from the reactions of $\mathrm{L}^{2} \mathrm{Li}$ and selected simple aluminum halide precursors.

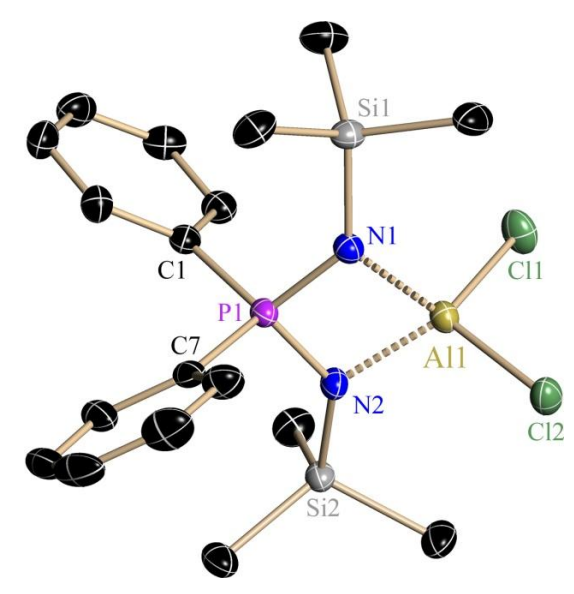

Molecular Structure of 23

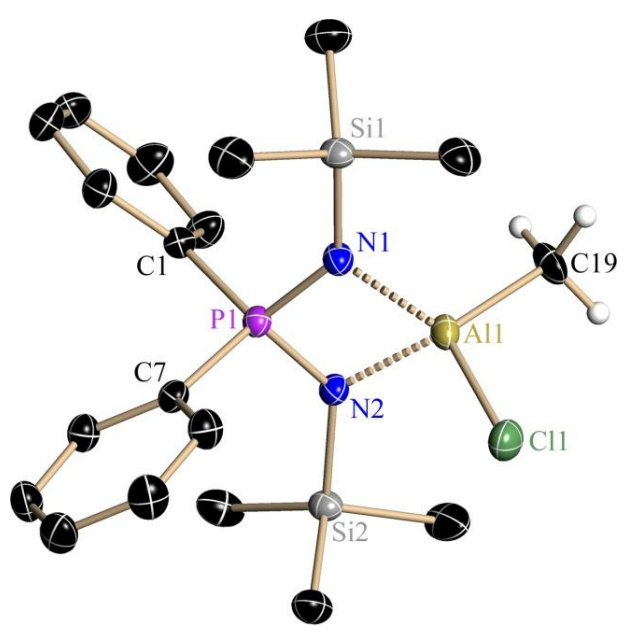

Molecular Structure of 24 
The reaction of the very bulky iminophosphonamide ligand $\mathrm{L}^{2} \mathrm{H}$ with $\mathrm{AlH}_{3} \cdot \mathrm{NMe}_{3}, \mathrm{AlEt}_{3}$ and $\left[\mathrm{Al}\left(\mathrm{NMe}_{2}\right)_{3}\right]_{2}$ afforded a dimeric aluminum monohydride $\mathrm{L}_{2}^{2} \mathrm{AlH}(\mathbf{2 5})$, an aluminum ethyl $\mathrm{L}^{2} \mathrm{AlEt}_{2}$ (26) and an aluminum amide $\mathrm{L}^{2} \mathrm{AlNMe}_{2}(\mathbf{2 7})$ complex, respectively.

In 25 the aluminum is five coordinate and in a distorted trigonal bipyramidal geometry. It could be a very useful precursor for the preparation of aluminum chalcogenide complexes.

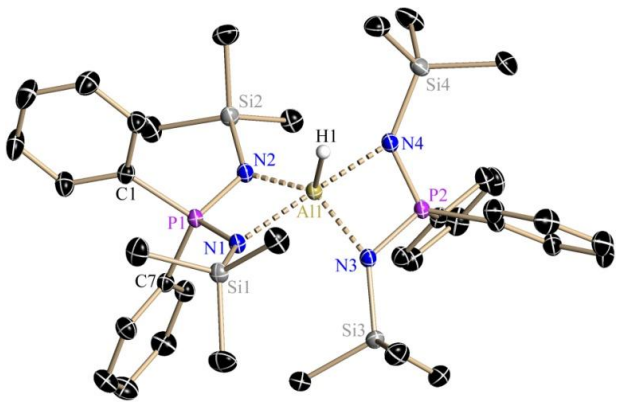

Molecular Structure of 25

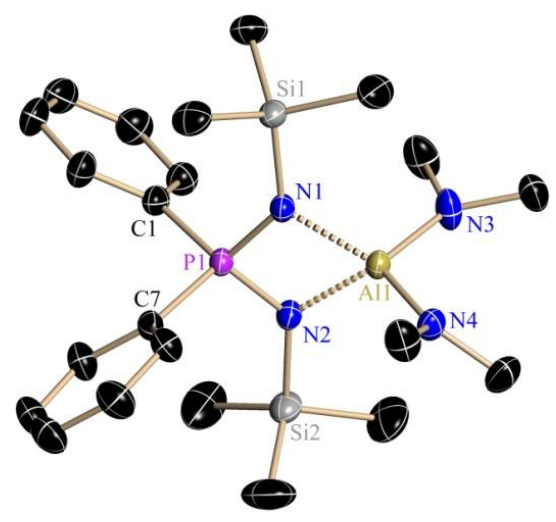

Molecular Structure of 27

\subsection{Outlook}

The thesis presented here has focussed on generating functionalities on bismuth and aluminum centers such as $\mathrm{NMe}_{2}$, halide, alkyl and $\mathrm{NH}_{2}$ and studying their reactivity. This resulted in the development of new synthetic strategies for generating such species.

Extension of this work may be the application of the carbene method for conversion of metal halides to the corresponding hydroxides and amides and as possible starting materials for reduction with the aim of obtaining metals in low oxidation states, and also for studying their involvement in different metathesis reactions. In summary, generation of such hydroxides has a huge synthetic potential in the field of well-defined heterobimetallic oxides. Moreover, other p-, d- or f- block metals are potential candidates for the generation of heterobimetallic complexes containing Bi-O-M and Al-O-M cores. 


\section{Experimental Section}

\subsection{General Procedures}

All experiments were carried out under an atmosphere of dry nitrogen or argon using Schlenk techniques or inside a glove-box filled with dry nitrogen, where the $\mathrm{O}_{2}$ and $\mathrm{H}_{2} \mathrm{O}$ level were strictly maintained below $1 \mathrm{ppm}$. Toluene, benzene, hexane, pentane, tetrahydrofuran, and diethylether were purified with the M-Braun solvent drying system. Dichloromethane $\left(\mathrm{CaH}_{2}\right)$ were dried and distilled prior to use. The samples for analytical measurements were prepared inside the glove box

\subsection{Physical Measurements}

The melting points of all compounds described in this thesis were measured on a Büchi B-540 apparatus in sealed capillaries and are uncorrected.

${ }^{1} \mathrm{H},{ }^{13} \mathrm{C},{ }^{27} \mathrm{Al},{ }^{29} \mathrm{Si}$, and ${ }^{31} \mathrm{P}$ NMR spectra were recorded on Bruker-Avance-500, Avance300 and Bruker-Avance-200 instruments. Deuterated NMR solvents $\mathrm{C}_{6} \mathrm{D}_{6}, \mathrm{C}_{7} \mathrm{H}_{8}$, and THF-D were dried by stirring for 2 days over $\mathrm{Na} / \mathrm{K}$ alloy followed by distillation in vacuo and degassed. The chemical shifts are reported in ppm with reference to external standards, positive shifts being downfield, $\mathrm{SiMe}_{4}$ for ${ }^{1} \mathrm{H},{ }^{13} \mathrm{C}$ and ${ }^{29} \mathrm{Si}$ nuclei, and $85 \% \mathrm{H}_{3} \mathrm{PO}_{4}$ for ${ }^{31} \mathrm{P}$ NMR. The operation temperature was in the range from 293 to $300 \mathrm{~K}$. The single types are assigned as follows: $\mathrm{s}=$ singlet, $\mathrm{d}=$ dublet, $\mathrm{t}=$ triplet, $\mathrm{q}=$ quartet, $\mathrm{m}=$ mutiplet.

IR spectra were recorded on a Bio-Rad Digilab FTS-7 spectrometer as Nujol mulls on $\mathrm{KBr}$ plates. Intensities were abbreviated as follows: s (strong), m (medium), w (weak). Only the characteristic absorptions are listed.

Mass spectra were obtained on a Finnigan MAT 8230 or a varian MAT CH5 instrument by EI-, FI- and FAB-MS techniques. Only the highest peak of an isotope distribution is given. 
Elemental analyses were performed at the Analytical Laboratory of the Institute of Inorganic Chemistry, University of Göttingen.

\subsection{Starting materials}

Commercially available chemicals were purchased from Fluka, Acros Organics or Aldrich and used as received. The other compounds used in this thesis were prepared according to published procedures: $\mathrm{BiCl}_{3}$ (Aldrich), $\mathrm{Li}\left(\mathrm{NMe}_{2}\right.$ ) (Aldrich), $\mathrm{AlEt}_{3}$ (Aldrich), $\mathrm{MeAlCl}_{2}$ (Aldrich), $\mathrm{AlCl}_{3}$ (Aldrich), $\mathrm{AlMe}_{3}(2.0 \mathrm{M}$ solution in $n$-hexane, Acros), MeLi (1.6 M in $\mathrm{Et}_{2} \mathrm{O}$, Acros Organics), sulfur (Aldrich), 1,8-diaminonaphthalene (Aldrich), hexamethyldisilazane (Fluka), $\mathrm{Cp}^{*}{ }_{2} \mathrm{ZrMe}_{2}$ (Fluka), $\mathrm{Cp}_{2}{ }_{2} \mathrm{HfCl}_{2}$ (Fluka), $\mathrm{AlH}_{3} \cdot \mathrm{NMe}_{3},{ }^{149} \mathrm{~N}, \mathrm{~N}^{\prime}-$

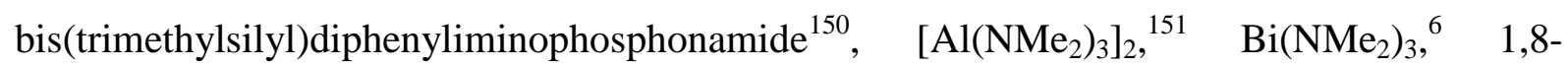
$\mathrm{C}_{10} \mathrm{H}_{6}(\mathrm{NHSiMe})_{2},{ }^{88,152} \mathrm{LMeM}(\mathrm{OH})(\mathrm{M}=\mathrm{Al}, \mathrm{Ga}),{ }^{153,154} \mathrm{LGe}(\mathrm{OH}),{ }^{155}\left(\mathrm{~L}=\mathrm{CH}(\mathrm{NAr}(\mathrm{CMe}))_{2}\right.$, $\left.\mathrm{Ar}=2,6-i \mathrm{Pr}_{2} \mathrm{C}_{6} \mathrm{H}_{3}\right), \mathrm{Cp}{ }_{2} \mathrm{MeZr}(\mathrm{OH}) .{ }^{156}$

\subsection{Synthesis}

\subsubsection{Synthesis of $\left[1,8-\mathrm{C}_{10} \mathrm{H}_{6}\left(\mathrm{NSiMe}_{3}\right)_{2} \mathrm{BiNMe}_{2}\right](1)$}

Compound $1,8-\mathrm{C}_{10} \mathrm{H}_{6}\left(\mathrm{NHSiMe}_{3}\right)_{2}(1.68 \mathrm{~g}, 5.55 \mathrm{mmol})$ in $n$-hexane $(30 \mathrm{~mL})$ was added to $\mathrm{Bi}\left(\mathrm{NMe}_{2}\right)_{3}(1.68 \mathrm{~g}, 5.55 \mathrm{mmol})$ in $n$-hexane $(30 \mathrm{~mL})$ at $-30{ }^{\circ} \mathrm{C}$ The reaction mixture was warmed to room temperature and stirred for additionally $12 \mathrm{~h}$. Then the mixture was concentrated and stored at $-30{ }^{\circ} \mathrm{C}$ in a freezer to obtain orange crystals. Yield: $2.39 \mathrm{~g}(78 \%)$; Mp $105{ }^{\circ} \mathrm{C} .{ }^{1} \mathrm{H}$ NMR $\left(500.13 \mathrm{MHz}, \mathrm{C}_{6} \mathrm{D}_{6}, 25^{\circ} \mathrm{C}, \mathrm{TMS}\right): \delta 7.42(\mathrm{~d}, 2 \mathrm{H}), 7.26(\mathrm{t}, 2 \mathrm{H}), 7.21(\mathrm{~d}$, $2 \mathrm{H}), 2.84(\mathrm{~s}, 6 \mathrm{H}), 0.25(\mathrm{~s}, 18 \mathrm{H}) .{ }^{13} \mathrm{C} \mathrm{NMR}\left(125.8 \mathrm{MHz}, \mathrm{C}_{6} \mathrm{D}_{6}, \mathrm{TMS}\right): \delta 147.8,130.7,138.3$, 126.5, 120.8, 116.8, 41.9, 3.0. ${ }^{29} \mathrm{Si}$ NMR $\left(99.3 \mathrm{MHz}, \mathrm{C}_{6} \mathrm{D}_{6}, 298 \mathrm{~K}\right): \delta 3.3$. Anal. Calcd for $\mathrm{C}_{18} \mathrm{H}_{30} \mathrm{BiN}_{3} \mathrm{Si}_{2}$ (553.18): C 39.05, H 5.46, N 7.59. Found: C 38.51, H 5.51, N 7.16. 


\subsubsection{Synthesis of $\mathrm{L}^{1} \mathrm{BiOCPh}(2-\mathrm{Py})\left(\mathrm{NMe}_{2}\right)(2)$}

A stirred solution of 2-benzoylpyridine $(0.19 \mathrm{~g}, 1.04 \mathrm{mmol})$ in $n$-hexane $(20 \mathrm{~mL})$ was added to a solution of $\mathrm{L}^{1} \mathrm{BiNMe}_{2}(\mathbf{1})\left[\mathrm{L}^{1}=1,8-\mathrm{C}_{10} \mathrm{H}_{6}\left(\mathrm{NSiMe}_{3}\right)_{2}\right](0.57 \mathrm{~g}, 1.04 \mathrm{mmol})$ in $n$ hexane $(20 \mathrm{~mL})$. The reaction was allowed to stir at room temperature for $1 \mathrm{~h}$. Then the mixture was concentrated and stored at $-30{ }^{\circ} \mathrm{C}$ in a freezer to obtain yellow crystals. Yield: 0.63g (83\%). ${ }^{1} \mathrm{H}$ NMR (500.13 MHz, $\left.\mathrm{C}_{6} \mathrm{D}_{6}, 25{ }^{\circ} \mathrm{C}, \mathrm{TMS}\right): \delta 8.06$ ( m, 1H), 7.42-7.53 (m, 5H), 7.30-7.33 (m, 2H), 7.09-7.16 (m, 3H), 6.91-6.97 (m, 3H), 6.50-6.53 (m, 1H), $1.59(\mathrm{~s}$,

$6 \mathrm{H}), 0.47(\mathrm{~s}, 9 \mathrm{H}), 0.32(\mathrm{~s}, 9 \mathrm{H}) .{ }^{13} \mathrm{C} \mathrm{NMR}\left(125.8 \mathrm{MHz}, \mathrm{C}_{6} \mathrm{D}_{6}, \mathrm{TMS}\right): \delta 166.9,149.5,148.21$, $145.5,138.7,137.1,130.5,126.9,126.6,124.3,122.1,119.8,118.9,116.1,94.8,38.68,3.15$, 3.06. ${ }^{29} \mathrm{Si} \mathrm{NMR}\left(99.3 \mathrm{MHz}, \mathrm{C}_{6} \mathrm{D}_{6}, 298 \mathrm{~K}\right): \delta 0.034,-0.81$. Anal. Calcd for $\mathrm{C}_{30} \mathrm{H}_{39} \mathrm{BiN}_{4} \mathrm{OSi}_{2}$ (736.81): C 48.9, H 5.34, N 7.60. Found: C 48.18, H 5.39, N 7.35.

\subsubsection{Synthesis of $\mathrm{L}^{1} \mathrm{BiOCH}(3-\mathrm{Py})\left(\mathrm{NMe}_{2}\right)(3)$}

A stirred solution of 3-pyridinecarboxaldehyde $(0.214 \mathrm{~g}, 2 \mathrm{mmol})$ in $n$-hexane $(20 \mathrm{~mL})$ was added to a solution of $\mathbf{1}(1.1 \mathrm{~g}, 2 \mathrm{mmol})$ in $n$-hexane $(20 \mathrm{~mL})$. The reaction mixture was allowed to stir at room temperature for $1 \mathrm{~h}$. Then the mixture was concentrated and stored at $-30{ }^{\circ} \mathrm{C}$ in a freezer to obtain yellow crystals. Yield: $0.97 \mathrm{~g}(75 \%)$; Mp $152{ }^{\circ} \mathrm{C} .{ }^{1} \mathrm{H}$ NMR (500.13 MHz, $\left.\mathrm{C}_{6} \mathrm{D}_{6}, 25^{\circ} \mathrm{C}, \mathrm{TMS}\right): \delta 8.2-8.29(\mathrm{~m}, 2 \mathrm{H}), 7.16-7.43(\mathrm{~m}, 6 \mathrm{H}), 6.48-6.69(\mathrm{~m}, 2 \mathrm{H})$, 5.05(s, 1H), $1.89(\mathrm{~s}, 6 \mathrm{H}), 0.30(\mathrm{~s}, 9 \mathrm{H}), 0.26(\mathrm{~s}, 9 \mathrm{H}) .{ }^{13} \mathrm{C} \mathrm{NMR}\left(125.8 \mathrm{MHz}, \mathrm{C}_{6} \mathrm{D}_{6}, \mathrm{TMS}\right): \delta$ $149.1,148.5,148.4,148.1,138.2,137.9,134.5,130.5,126.7,122.7,120.6,116.7,116.2$,

89.23, 39.35, 3.06, 3.05. ${ }^{29} \mathrm{Si} \mathrm{NMR}\left(99.3 \mathrm{MHz}, \mathrm{C}_{6} \mathrm{D}_{6}, 298 \mathrm{~K}\right): \delta 1.92$, 1.77. Anal. Calcd for $\mathrm{C}_{24} \mathrm{H}_{35} \mathrm{BiN}_{4} \mathrm{OSi}_{2}$ (660.71): C 43.63, H 5.34, N 8.48. Found: C 43.79, H 5.53, N 8.27. 


\subsubsection{Synthesis of $\mathrm{L}^{1} \mathrm{BiC}(\mathrm{Me})(\mathrm{CN}) \mathrm{CH}_{2} \mathrm{NMe}_{2}(4)$}

A stirred solution of 2-methyl-2- propenenitrile $(0.09 \mathrm{~g}, 1.34 \mathrm{mmol})$ in $n$-hexane $(20 \mathrm{~mL})$ was added to a solution of $\mathbf{1}(0.74 \mathrm{~g}, 1.34 \mathrm{mmol})$ in $n$-hexane $(20 \mathrm{~mL})$. The reaction was allowed to stir at room temperature for $12 \mathrm{~h}$. Then the mixture was concentrated and stored at $-30{ }^{\circ} \mathrm{C}$ in a freezer to obtain yellow crystals of 4 . Yield: $0.61 \mathrm{~g}(74 \%)$; Mp $108{ }^{\circ} \mathrm{C} .{ }^{1} \mathrm{H}$ NMR (500.13 MHz, $\left.\mathrm{C}_{6} \mathrm{D}_{6}, 25^{\circ} \mathrm{C}, \mathrm{TMS}\right): \delta 7.19-7.4(\mathrm{~m}, 5 \mathrm{H}), 7.01-7.06(\mathrm{~m}, 1 \mathrm{H}), 4.53(\mathrm{~d}, 1 \mathrm{H}), 2.43$ (d, 1H), $2.08(\mathrm{~s}, 6 \mathrm{H}), 1.17$ (s, 3H), $0.43(\mathrm{~s}, 9 \mathrm{H}), 0.16(\mathrm{~s}, 9 \mathrm{H}) .{ }^{13} \mathrm{C} \mathrm{NMR}\left(125.8 \mathrm{MHz}, \mathrm{C}_{6} \mathrm{D}_{6}\right.$, TMS): $\delta 149.4,147.2,138.5,130.5,126.7,125.8,124.2,122.5,119.2,116.8,62.6,46.7,18.4$

3.1, 2.8. ${ }^{29} \mathrm{Si}$ NMR $\left(99.3 \mathrm{MHz}, \mathrm{C}_{6} \mathrm{D}_{6}, 298 \mathrm{~K}\right): \delta 5.41,3.46$. Anal. Calcd for $\mathrm{C}_{22} \mathrm{H}_{35} \mathrm{BiN}_{4} \mathrm{Si}_{2}$ (620.69): C 42.57, H 5.68, N 9.03. Found: C 41.61, H 5.71, N 9.03.

\subsubsection{Synthesis of $\mathrm{L}^{1} \mathrm{BiC}\left(\mathrm{CO}_{2} \mathrm{Et}\right) \mathrm{CNMe}_{2}\left(\mathrm{CONMe}_{2}\right)(5)$}

A stirred solution of diethyl acetylenedicarboxylate $(0.104 \mathrm{~g}, 0.614 \mathrm{mmol})$ in $n$-hexane $(20 \mathrm{~mL})$ was added to a solution of $\mathbf{1}(0.68 \mathrm{~g}, 1.23 \mathrm{mmol})$ in $n$-hexane $(20 \mathrm{~mL})$. The reaction was allowed to stir at room temperature for $12 \mathrm{~h}$. Then the mixture was concentrated and stored at $-30{ }^{\circ} \mathrm{C}$ in a freezer to obtain yellow crystals of $\mathbf{5}$. Yield: $0.24 \mathrm{~g}(55 \%)$; $\mathrm{Mp} 138{ }^{\circ} \mathrm{C}$. ${ }^{1} \mathrm{H}$ NMR (300.13 MHz, $\left.\mathrm{C}_{6} \mathrm{D}_{6}\right): \delta$ 7.07-7.28 (m, 5H), 6.84-76.89 (m, 1H), 3.81-4.11 (m, 2H), $2.43(\mathrm{~s}, 6 \mathrm{H}), 2.42(\mathrm{~s}, 3 \mathrm{H}), 1.29(\mathrm{~s}, 3 \mathrm{H}), 0.91(\mathrm{t}, 3 \mathrm{H}), 0.52(\mathrm{~s}, 9 \mathrm{H}), 0.22(\mathrm{~s}, 9 \mathrm{H}),{ }^{13} \mathrm{C} \mathrm{NMR}$ $\left(75.47 \mathrm{MHz}, \mathrm{C}_{6} \mathrm{D}_{6}\right): \delta 174.4,169.3,159.6,151.3,150.5,138.6,133.0,126.6,125.9,119.7$, 118.2, 115.7, 114.7, 60.2, 40.9, 36.2, 33.4, 14.9, 3.3, 3.2. ${ }^{29} \mathrm{Si}$ NMR $\left(59.62 \mathrm{MHz}, \mathrm{C}_{6} \mathrm{D}_{6}\right): \delta$ 2.154, 1.951. IR (Nujol, $\left.\mathrm{cm}^{-1}\right): \widetilde{v}=1638,1554,1475,1375,1327,1280,1245,1068,1041$, 892, 862, 832, 755. Anal. Calcd for $\mathrm{C}_{26} \mathrm{H}_{41} \mathrm{BiN}_{4} \mathrm{O}_{3} \mathrm{Si}_{2}$ (722.79): C 43.21, H 5.72, N 7.75. Found: C 43.41, H 5.46, N 7.46. 


\subsubsection{Synthesis of $1,8-\mathrm{C}_{10} \mathrm{H}_{6}\left(\mathrm{NSiMe}_{3}\right)_{2} \mathrm{Bi}(\mathrm{NiPr})_{2} \mathrm{CNMe}_{2}(6)$}

To a stirred solution of N,N'-diisopropylcarbodiimide $(0.1 \mathrm{~g}, 0.79 \mathrm{mmol})$ in $n$-hexane (20 $\mathrm{mL})$ was added a solution of $1(0.42 \mathrm{~g}, 0.76 \mathrm{mmol})$ in $n$-hexane $(20 \mathrm{~mL})$. The reaction was allowed to stir at room temperature for $12 \mathrm{~h}$. Then the mixture was concentrated and stored at $-30{ }^{\circ} \mathrm{C}$ in a freezer to obtain yellow crystals of 6 . Yield: $0.4 \mathrm{~g}(78 \%)$; Mp $116^{\circ} \mathrm{C} .{ }^{1} \mathrm{H}$ NMR (500.13 MHz, $\left.\mathrm{C}_{6} \mathrm{D}_{6}\right): \delta 7.11-7.43$ (m, 6H), 3.93 (sept, 2H), 1.99 (s. 6H), 0.94 (d, 12H), 0.34 (s, 18H). ${ }^{13} \mathrm{C}$ NMR $\left(125.8 \mathrm{MHz}, \mathrm{C}_{6} \mathrm{D}_{6}\right): \delta 166.5,150.2,138.2,132.4,126.2,119.8,117.3$, 47.3, 39.7, 24.9, 2.7. ${ }^{29} \mathrm{Si} \mathrm{NMR}\left(59.6 \mathrm{MHz}, \mathrm{C}_{6} \mathrm{D}_{6}\right): \delta 0.21$.

\subsubsection{Synthesis of $1,8-\mathrm{C}_{10} \mathrm{H}_{6}\left(\mathrm{NSiMe}_{3}\right)_{2} \mathrm{BiNPhCONMe}_{2}$ (7).}

To a stirred solution of phenylisocyanate $(0.19 \mathrm{~g}, 1.6 \mathrm{mmol})$ in $n$-hexane $(20 \mathrm{~mL})$ was added a solution of $\mathbf{1}(0.88 \mathrm{~g}, 1.6 \mathrm{mmol})$ in $n$-hexane $(20 \mathrm{~mL})$. The reaction was allowed to stir at room temperature for $12 \mathrm{~h}$. Then the mixture was concentrated and stored at $-30{ }^{\circ} \mathrm{C}$ in a freezer to obtain yellow crystals of 7. Yield: $0.73 \mathrm{~g}$ (69\%); Mp $151{ }^{\circ} \mathrm{C} .{ }^{1} \mathrm{H}$ NMR $(500.13$ $\left.\mathrm{MHz}, \mathrm{C}_{6} \mathrm{D}_{6}\right): \delta 7.31-7.36(\mathrm{~m}, 2 \mathrm{H}), 7.16-7.22(\mathrm{~m}, 2 \mathrm{H}), 6.97-7.03(\mathrm{~m}, 2 \mathrm{H}), 6.84-6.91(\mathrm{~m}, 2 \mathrm{H})$, 6.59-6.66 (m, 1H), 6.18-6.23 (m, 2H), $2.08(\mathrm{~s}, 6 \mathrm{H}), 0.31(\mathrm{~s}, 18 \mathrm{H}) .{ }^{13} \mathrm{C}$ NMR $(125.8 \mathrm{MHz}$, $\left.\mathrm{C}_{6} \mathrm{D}_{6}\right): \delta 148.2,144.3,138.4,130.6,126.5,126,123.8,119.5,115.5,37.5,2.71 .{ }^{29} \mathrm{Si}$ NMR (59.6 MHz, $\left.\mathrm{C}_{6} \mathrm{D}_{6}\right): \delta$ 2.93. Anal. Calcd for $\mathrm{C}_{25} \mathrm{H}_{35} \mathrm{BiN}_{4} \mathrm{OSi}_{2}: \mathrm{C}, 44.63 ; \mathrm{H}, 5.24 ; \mathrm{N}, 8.33$. Found: C, 44.99; H, 5.51; N, 8.26.

\subsubsection{Synthesis of $1,8-\mathrm{C}_{10} \mathrm{H}_{6}\left(\mathrm{NSiMe}_{3}\right)_{2} \mathrm{Bi}(\mu-\mathrm{O}) \mathrm{AlMeL}(8)$}

$n$-Hexane $(40 \mathrm{~mL})$ was added to a mixture of $\mathrm{LMeAl}(\mathrm{OH})(0.33 \mathrm{~g}, 0.69 \mathrm{mmol})$ $\left(\mathrm{L}=\mathrm{CH}(\mathrm{NAr}(\mathrm{CMe}))_{2}, \mathrm{Ar}=2,6-i \mathrm{Pr}_{2} \mathrm{C}_{6} \mathrm{H}_{3}\right)$ and $1(0.38 \mathrm{~g}, 0.69 \mathrm{mmol})$. The resulting solution was stirred for $12 \mathrm{~h}$ at room temperature. After concentration and keeping the solution at -30 ${ }^{\circ} \mathrm{C}$ in a freezer yellow crystals of 8 were isolated. Yield $0.47 \mathrm{~g},(69 \%)$; Mp $174{ }^{\circ} \mathrm{C} .{ }^{1} \mathrm{H}$ NMR 
(300.13 MHz, $\left.\mathrm{C}_{6} \mathrm{D}_{6}\right): \delta 6.95-7.24(\mathrm{~m}, 12 \mathrm{H}), 4.68(\mathrm{~s}, 1 \mathrm{H}), 3.06-3.18(\mathrm{~m}, 4 \mathrm{H}), 1.47(\mathrm{~s}, 6 \mathrm{H})$, $1.31(\mathrm{~d}, 6 \mathrm{H}), 1.14(\mathrm{~d}, 6 \mathrm{H}), 1.08(\mathrm{~d}, 6 \mathrm{H}), 0.99(\mathrm{~d}, 6 \mathrm{H}), 0.24(\mathrm{~s}, 18 \mathrm{H}),-0.69(\mathrm{~s}, 3 \mathrm{H}) \mathrm{ppm} .{ }^{13} \mathrm{C}$ NMR (75.47 MHz, $\left.\mathrm{C}_{6} \mathrm{D}_{6}\right): \delta 169,146.6,144.4,139.9,137.8,129.6,127,126.2,124.4,124.3$, 120.2, 116.6, 96.1, 28.6, 27.6, 26.2, 25.1, 24.9, 24.7, 23.2, 3.15, -8.4 ppm. ${ }^{29} \mathrm{Si}$ NMR (59.6

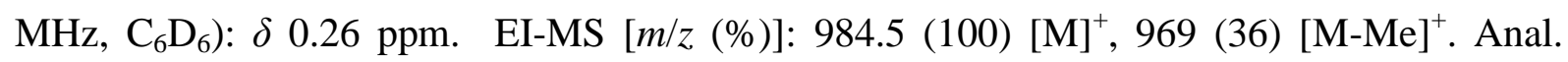
Calcd for $\mathrm{C}_{46} \mathrm{H}_{68} \mathrm{AlBiN}_{4} \mathrm{OSi}_{2}$ (985.2): C, 56.08; H, 6.96; N, 5.69. Found: C, 55.88; H, 7.11; $\mathrm{N}, 5.78$.

\subsubsection{Synthesis of $1,8-\mathrm{C}_{10} \mathrm{H}_{6}\left(\mathrm{NSiMe}_{3}\right)_{2} \mathrm{Bi}(\mu-\mathrm{O}) \mathrm{GaMeL}(9)$}

$n$-Hexane $(40 \mathrm{~mL})$ was added to a mixture of $\mathrm{LMeGa}(\mathrm{OH})(0.37 \mathrm{~g}, 0.71 \mathrm{mmol})$ and $\mathbf{1}$ $(0.4 \mathrm{~g}, 0.71 \mathrm{mmol})$. The resulting solution was stirred for $12 \mathrm{~h}$ at room temperature. Yellow crystals of 9 were isolated from the mixture of $n$-hexane/toluene solution $(3: 1 \mathrm{v} / \mathrm{v})$ at $-30{ }^{\circ} \mathrm{C}$ in a freezer. Yield $0.39 \mathrm{~g},(54 \%)$; $\mathrm{Mp} 191{ }^{\circ} \mathrm{C} .{ }^{1} \mathrm{H} \mathrm{NMR}\left(300.13 \mathrm{MHz}, \mathrm{C}_{6} \mathrm{D}_{6}\right): \delta 6.96-7.23$ $(\mathrm{m}, 12 \mathrm{H}), 4.57(\mathrm{~s}, 1 \mathrm{H}), 3.15-3.23(\mathrm{~m}, 4 \mathrm{H}), 1.57(\mathrm{~s}, 6 \mathrm{H}), 1.28(\mathrm{~d}, 6 \mathrm{H}), 1.14(\mathrm{~d}, 6 \mathrm{H}), 1.09(\mathrm{~d}$, $6 \mathrm{H}), 1.02(\mathrm{~d}, 6 \mathrm{H}), 0.28(\mathrm{~s}, 18 \mathrm{H}),-0.56(\mathrm{~s}, 3 \mathrm{H}) \mathrm{ppm} .{ }^{13} \mathrm{C} \mathrm{NMR}\left(125.7 \mathrm{MHz}, \mathrm{C}_{6} \mathrm{D}_{6}\right): \delta 167.7$, $146.7,144.7,140.4,137.8,129.7,127,126.2,124.4,124.3,120.2,116.6,96,28.8,27.8,26.3$, 25.2, 24.7, 24.6, 23.3, 3.17, -6.5 ppm. $\left.{ }^{29} \mathrm{Si} \mathrm{NMR} \mathrm{(99.3} \mathrm{MHz,} \mathrm{C}_{6} \mathrm{D}_{6}\right): \delta 0.52 \mathrm{ppm}$. Anal. Calcd for $\mathrm{C}_{46} \mathrm{H}_{68} \mathrm{BiGaN}_{4} \mathrm{OSi}_{2}(1027.9)$ : C, 53.75; H, 6.67; N, 5.45. Found: C, 53.26; H, 6.71; N, 5.61 .

\subsubsection{Synthesis of $1,8-C_{10} \mathrm{H}_{6}\left(\mathrm{NSiMe}_{3}\right)_{2} \mathrm{Bi}(\mu-\mathrm{O}) \mathrm{GeL}(10)$}

n-Hexane $(30 \mathrm{~mL})$ was added to a mixture of $\mathrm{LGe}(\mathrm{OH})(0.32 \mathrm{~g}, 0.63 \mathrm{mmol})$ and $\mathbf{1}(0.35$ $\mathrm{g}, 0.63 \mathrm{mmol})$. The resulting solution was stirred for $12 \mathrm{~h}$ at room temperature. After concentration and keeping the solution at $-30{ }^{\circ} \mathrm{C}$ in a freezer yellow crystals of $\mathbf{1 0}$ were isolated. Yield $0.41 \mathrm{~g},(63 \%)$; $\mathrm{Mp} 251{ }^{\circ} \mathrm{C} .{ }^{1} \mathrm{H}$ NMR $\left(300.13 \mathrm{MHz}, \mathrm{C}_{6} \mathrm{D}_{6}\right): \delta 6.91-7.19(\mathrm{~m}$, 12H), 4.56 (s, 1H), 3.37 (sept, 2H), 3.14 (sept, 2H), 1.47 (s, 6H), 1.28 (d, 6H), 1.20 (d, 6H), 
$1.04(\mathrm{~d}, 6 \mathrm{H}), 1.07(\mathrm{~d}, 6 \mathrm{H}), 0.24(\mathrm{~s}, 18 \mathrm{H}) \mathrm{ppm} .{ }^{13} \mathrm{C} \mathrm{NMR}\left(75.47 \mathrm{MHz}, \mathrm{C}_{6} \mathrm{D}_{6}\right): \delta 162.6,146.7$, $145.2,144,139,137.7,130.1,126.8,126.4,124.4,120.5,116.7,95,31.9,28.7,28.3,26.8$, 25.1, 24.8, 22.9, 22.6, 14.2, 3.0 ppm. ${ }^{29} \mathrm{Si}$ NMR (59.6 MHz, $\left.\mathrm{C}_{6} \mathrm{D}_{6}\right): \delta 0.99 \mathrm{ppm}$. EI-MS $[\mathrm{m} / \mathrm{z}$ $(\%)]: \quad 1016.4 \quad(100) \quad[\mathrm{M}]^{+}, \quad 599 \quad(62) \quad\left[\mathrm{M}-\mathrm{CH}(\mathrm{DippNCMe})_{2}\right]^{+} . \quad$ Anal. $\quad$ Calcd for $\mathrm{C}_{48} \mathrm{H}_{72} \mathrm{BiGeN}_{4} \mathrm{OSi}_{2}\left(1058.85,10 \cdot \mathrm{C}_{7} \mathrm{H}_{8}\right): \mathrm{C}, 54.39 ; \mathrm{H}, 6.79 ; \mathrm{N}, 5.28$. Found: $\mathrm{C}, 53.64 ; \mathrm{H}$, $6.79 ; \mathrm{N}, 5.28$.

\subsubsection{Synthesis of 1,8- $\mathrm{C}_{10} \mathrm{H}_{6}\left(\mathrm{NSiMe}_{3}\right)_{2} \mathrm{Bi}(\mu-\mathrm{O}) \mathrm{ZrMeCp}_{2}{ }_{2}(11)$}

n-Hexane $(40 \mathrm{~mL})$ was added to $\mathrm{Cp}^{*}{ }_{2} \mathrm{MeZr}(\mathrm{OH})(0.43 \mathrm{~g}, 1.1 \mathrm{mmol})$ and 1 (0.6 g, 1.1 mmol). The resulting solution was stirred for $12 \mathrm{~h}$ at room temperature, and then the solvent was partly removed and the solution kept at $-30{ }^{\circ} \mathrm{C}$ in a freezer. Yellow crystals of $\mathbf{1 1}$ were isolated after 2 days. Yield $0.72 \mathrm{~g},(73 \%)$; Mp $206{ }^{\circ} \mathrm{C} .{ }^{1} \mathrm{H}$ NMR $\left(300.13 \mathrm{MHz}, \mathrm{C}_{6} \mathrm{D}_{6}\right): \delta$ 7.44-7.47 (m, 2H), 7.17-7.31 (m, 4H), $1.63(\mathrm{~s}, 30 \mathrm{H}), 0.28(\mathrm{~s}, 18 \mathrm{H}),-043(\mathrm{~s}, 3 \mathrm{H}) \mathrm{ppm} .{ }^{13} \mathrm{C}$ NMR (75.47 MHz, $\left.\mathrm{C}_{6} \mathrm{D}_{6}\right): \delta 147.2,138.5,130.4,126.8,120.4,118.7,117.2,25.7,11.3,3.07$

ppm. ${ }^{29} \mathrm{Si}$ NMR (59.6 MHz, $\left.\mathrm{C}_{6} \mathrm{D}_{6}\right): \delta 1.1 \mathrm{ppm}$. EI-MS [m/z (\%)]: 524.2 (78) [M$\left.\mathrm{Cp}^{*}{ }_{2} \mathrm{Zr}(\mathrm{Me})-\mathrm{H}\right]^{+}, 494.1$ (100) $\left[\mathrm{M}-\mathrm{Cp}^{*}{ }_{2} \mathrm{Zr}(\mathrm{Me})-\mathrm{OMe}\right]^{+}$. Anal. Calcd for $\mathrm{C}_{37} \mathrm{H}_{57} \mathrm{BiN}_{2} \mathrm{OSi} \mathrm{Zr}_{2}$ (902.23): C, 49.25; H, 6.37; N, 3.10. Found: C, 48.78; H, 6.39; N, 3.19.

\subsubsection{Synthesis of $1,8-C_{10} \mathrm{H}_{6}\left(\mathrm{NSiMe}_{3}\right)_{2} \mathrm{Bi}(\mu-\mathrm{O}) \mathrm{HfClCp}_{2}{ }_{2}(12)$}

To a solution of $\mathrm{Cp}^{*}{ }_{2} \mathrm{HfCl}_{2}(0.445 \mathrm{~g}, 0.846 \mathrm{mmol})$ and $\left[\mathrm{CN}(i \mathrm{Pr}) \mathrm{C}_{2} \mathrm{Me}_{2} \mathrm{~N}(i \mathrm{Pr})\right](: \mathrm{C}, 0.15$ $\mathrm{g}, 0.846 \mathrm{mmol})$ in toluene $(60 \mathrm{~mL})$ degassed and distilled water $(15 \mu \mathrm{L}, 0.846 \mathrm{mmol})$ was slowly added under vigorous stirring over a period of $30 \mathrm{~min}$. The mixture was stirred for another $30 \mathrm{~min}$ and the formation of a white precipitate was observed. The resulting solid was filtered off and the filtrate was added to a flask containing $1(0.47 \mathrm{~g}, 0846 \mathrm{mmol})$ at -30 ${ }^{\circ} \mathrm{C}$. The mixture was stirred for $1 \mathrm{~h}$ at this temperature and then was allowed to attain room temperature and stirring was continued for $12 \mathrm{~h}$. All volatiles were removed in vacuo and the 
resulting solid was washed with $n$-hexane $(20 \mathrm{~mL})$ to give yellow crystalline 12 . The product was recrystallized from a toluene/ $n$-hexane $(2: 1 \mathrm{v} / \mathrm{v})$ mixture to yield yellow crystals at -30 ${ }^{\circ} \mathrm{C}$. Yield $0.29 \mathrm{~g}(34 \%)$; $\mathrm{Mp} 210{ }^{\circ} \mathrm{C} .{ }^{1} \mathrm{H}$ NMR $\left(300.13 \mathrm{MHz}, \mathrm{C}_{6} \mathrm{D}_{6}\right): \delta$ 7.44-7.47 (m, 2H), 7.22-7.34 (m, 4H), $1.73(\mathrm{~s}, 30 \mathrm{H}), 0.3(\mathrm{~s}, 18 \mathrm{H}) \mathrm{ppm} .{ }^{13} \mathrm{C} \mathrm{NMR}\left(75.47 \mathrm{MHz}, \mathrm{C}_{6} \mathrm{D}_{6}\right): \delta 147.8$, 138.5, 126.8, 120.3, 119.6, 116.8, 11.5, 2.9 ppm. ${ }^{29} \mathrm{Si}$ NMR (59.62 MHz, $\left.\mathrm{C}_{6} \mathrm{D}_{6}\right): \delta 1.12 \mathrm{ppm}$. EI-MS $\quad[m / z \quad(\%)]: \quad 1010.5 \quad(43) \quad[M]^{+}, \quad 875 \quad(100) \quad[\mathrm{M}-\mathrm{Cp} *]^{+} . \quad$ Anal. Calcd for $\mathrm{C}_{36} \mathrm{H}_{54} \mathrm{BiClHfN}_{2} \mathrm{OSi}_{2}$ (1009.91): C, 42.77; H, 5.34; N, 2.77. Found: C, 42.40; H, 5.35; N, 2.80.

\subsubsection{Synthesis of 1,8- $\mathrm{C}_{10} \mathrm{H}_{6}\left(\mathrm{NSiMe}_{3}\right)_{2} \mathrm{BiCl}(13)$}

To a stirred solution of $1(0.7 \mathrm{~g}, 1.26 \mathrm{mmol})$ in $n$-hexane $(30 \mathrm{~mL})$ was added $0.16 \mathrm{~mL}$ (1.26 mmol) of $\mathrm{ClSiMe}_{3}$ at $-10^{\circ} \mathrm{C}$. The reaction mixture was warmed to room temperature and stirred over night. All volatiles were removed in vacuo and the resulting solid was washed with cold $n$-hexane $(20 \mathrm{~mL})$ to give red crystalline solid. The product was recrystallized from a toluene/ $n$-hexane mixture $(2: 1)$ to yield red crystals of $\mathbf{1 3}$ at $-30{ }^{\circ} \mathrm{C}$. Yield: 0.47g (69\%); Mp $163{ }^{\circ} \mathrm{C} .{ }^{1} \mathrm{H}$ NMR (500.13 MHz, $\left.\mathrm{C}_{6} \mathrm{D}_{6}\right): \delta 7.41(\mathrm{~d} 2 \mathrm{H}), 7.28(\mathrm{t}, 2 \mathrm{H})$, $7.16(\mathrm{~d} 2 \mathrm{H}), 0.17(\mathrm{~s}, 18 \mathrm{H}) .{ }^{13} \mathrm{C} \mathrm{NMR}\left(125.8 \mathrm{MHz}, \mathrm{C}_{6} \mathrm{D}_{6}\right): \delta 146.53,138,131.7,126.8,121.1$, 116.3, 2.65. ${ }^{29} \mathrm{Si}$ NMR (59.6 MHz, $\left.\mathrm{C}_{6} \mathrm{D}_{6}\right): \delta$ 4.6. Anal. Calcd for $\mathrm{C}_{16} \mathrm{H}_{24} \mathrm{BiClN}_{2} \mathrm{Si}_{2}: \mathrm{C}, 35.26$; H, 4.44; N, 5.14. Found: C, 34.92; H, 4.21; N 5.09.

\subsubsection{Synthesis of 1,8- $\mathrm{C}_{10} \mathrm{H}_{6}\left(\mathrm{NSiMe}_{3}\right)_{2} \mathrm{BiC} \equiv \mathrm{CPh}(14)$}

To a stirred solution of $1(0.7 \mathrm{~g}, 1.26 \mathrm{mmol})$ in $n$-hexane $(30 \mathrm{~mL})$ was added $0.14 \mathrm{~mL}$ $(1.26 \mathrm{mmol})$ of phenyl acetylene at $-10{ }^{\circ} \mathrm{C}$. The reaction mixture was warmed to room temperature and stirred over night. Then the mixture was concentrated and stored at $-30{ }^{\circ} \mathrm{C}$ in a freezer. Orange crystals of $\mathbf{1 4}$ were obtained after two days. Yield: $0.41 \mathrm{~g}$ (54\%); Mp 98 
${ }^{\circ} \mathrm{C} .{ }^{1} \mathrm{H}$ NMR $\left(500.13 \mathrm{MHz}, \mathrm{C}_{6} \mathrm{D}_{6}\right): \delta$ 7.48-7.51 (m, 2H), 7.24-7.31 (m, 3H), 6.85-6.89 (m, $2 \mathrm{H}), 6.74-6.77(\mathrm{~m}, 3 \mathrm{H}), 0.23(\mathrm{~s}, 18 \mathrm{H}) .{ }^{13} \mathrm{C}$ NMR $\left(125.8 \mathrm{MHz}, \mathrm{C}_{6} \mathrm{D}_{6}\right): \delta 150.1,138,134$, 131.9, 126.4, 123.7, 120.6, 116.2, 111.9, 3.1. ${ }^{29} \mathrm{Si} \mathrm{NMR}\left(59.6 \mathrm{MHz}, \mathrm{C}_{6} \mathrm{D}_{6}\right): \delta$ 4.1. Anal. Calcd for $\mathrm{C}_{24} \mathrm{H}_{29} \mathrm{BiN}_{2} \mathrm{Si}_{2}$ : C, 47.2; H, 4.79; N, 4.59. Found: C, 46.66; H, 4.80; N, 4.42.

\subsubsection{Synthesis of $1,8-\mathrm{C}_{10} \mathrm{H}_{6}\left(\mathrm{NSiMe}_{3}\right)_{2} \mathrm{BiCp}^{*}(15)$}

The $n$-hexane solution $(30 \mathrm{~mL})$ of $\mathbf{1}(0.28 \mathrm{~g}, 0.5 \mathrm{mmol})$ was added to a $n$-hexane solution $(20 \mathrm{~mL})$ of $\mathrm{Cp}^{*} \mathrm{H}(0.07 \mathrm{~g}, 0.5 \mathrm{mmol})$ at room temperature. The reaction mixture was stirred over night, then concentrated and stored at $-30{ }^{\circ} \mathrm{C}$ in a freezer to obtain orange crystals of $\mathbf{1 5}$. Yield: $0.22 \mathrm{~g}(68 \%)$; $\mathrm{Mp} 148{ }^{\circ} \mathrm{C} .{ }^{1} \mathrm{H}$ NMR (500.13 MHz, $\left.\mathrm{C}_{6} \mathrm{D}_{6}\right): \delta 7.23-7.41(\mathrm{~m}, 6 \mathrm{H}), 1.86$ (s, 315H), $0.27(\mathrm{~s}, 18 \mathrm{H}) .{ }^{13} \mathrm{C}$ NMR $\left(125.8 \mathrm{MHz}, \mathrm{C}_{6} \mathrm{D}_{6}\right): \delta 148.8,138.9,130.3,127.8,126.6$, 124.5, 120.3, 117.7, 10.4, 3.3. ${ }^{29} \mathrm{Si}$ NMR (59.6 MHz, $\left.\mathrm{C}_{6} \mathrm{D}_{6}\right): \delta$ 1.14. Anal. Calcd for $\mathrm{C}_{26} \mathrm{H}_{39} \mathrm{BiN}_{2} \mathrm{Si}_{2}:$ C, 48.43; H, 6.10; N, 4.34. Found: C, 47.94; H, 5.98; N, 4.45.

\subsubsection{Synthesis of 1,8- $\mathrm{C}_{10} \mathrm{H}_{6}\left(\mathrm{NSiMe}_{3}\right)_{2} \mathrm{BiMe}(16)$}

$\mathrm{AlMe}_{3}(0.8 \mathrm{~mL}, 1.6 \mathrm{mmol}, 2.0 \mathrm{M}$ in $n$-hexane) was added to a $n$-hexane (50 mL) solution of $1(0.88 \mathrm{~g}, 1.6 \mathrm{mmol})$ at $-78{ }^{\circ} \mathrm{C}$. The mixture was stirred for $1 \mathrm{~h}$ at this temperature and then was allowed to attain room temperature and stirring was continued for $12 \mathrm{~h}$. The mixture was concentrated and stored at $-30{ }^{\circ} \mathrm{C}$ in a freezer to give yellow microcrystalline solid of $\mathbf{1 7}$. Yield: $0.31 \mathrm{~g}(37 \%)$; $\mathrm{Mp} 109{ }^{\circ} \mathrm{C} .{ }^{1} \mathrm{H}$ NMR (500.13 MHz, $\left.\mathrm{C}_{6} \mathrm{D}_{6}\right): \delta 7.23-7.31(\mathrm{~m}, 4 \mathrm{H}), 7.44-$ $7.48(\mathrm{~m}, 2 \mathrm{H}), 0.43(\mathrm{~s}, 3 \mathrm{H}), 0.28(\mathrm{~s}, 18 \mathrm{H}) .{ }^{13} \mathrm{C} \mathrm{NMR}\left(125.8 \mathrm{MHz}, \mathrm{C}_{6} \mathrm{D}_{6}\right): \delta 149.2,138.4,131.2$ 126.2, 120.7, 117.9, 3.3, - 9.6. ${ }^{29} \mathrm{Si} \mathrm{NMR}\left(59.6 \mathrm{MHz}, \mathrm{C}_{6} \mathrm{D}_{6}\right): \delta$ 3.7. Anal. Calcd for $\mathrm{C}_{17} \mathrm{H}_{27} \mathrm{BiN}_{2} \mathrm{Si}_{2}:$ C, 38.92; H, 5.19; N, 5.34. Found: C, 38.75; H, 5.11; N, 5.46. 


\subsubsection{Synthesis of 1,8- $\mathrm{C}_{10} \mathrm{H}_{6}\left(\mathrm{NSiMe}_{3}\right)_{2} \mathrm{BiOPh}(17)$}

$n$-Hexane $(40 \mathrm{~mL})$ was added to the mixture of $\mathbf{1}(0.7 \mathrm{~g}, 1.26 \mathrm{mmol})$ and phenol $(0.12 \mathrm{~g}$, $1.26 \mathrm{mmol}$ ) at room temperature and stirred over night. After filtration the resulting solution concentrated and stored at $-30{ }^{\circ} \mathrm{C}$ in a freezer to obtain a yellow crystals of 17. Yield: $0.48 \mathrm{~g}$

(64\%); Mp $149{ }^{\circ} \mathrm{C} .{ }^{1} \mathrm{H}$ NMR $\left(500.13 \mathrm{MHz}, \mathrm{C}_{6} \mathrm{D}_{6}\right): \delta 7.41(\mathrm{~d}, 2 \mathrm{H}), 7.24(\mathrm{t}, 2 \mathrm{H}), 6.94-7.02(\mathrm{~m}$, $4 \mathrm{H}), 6.65(\mathrm{t}, 1 \mathrm{H}), 6.29(\mathrm{~d}, 2 \mathrm{H}), 0.11(\mathrm{~s}, 18 \mathrm{H}) .{ }^{13} \mathrm{C} \mathrm{NMR}\left(125.8 \mathrm{MHz}, \mathrm{C}_{6} \mathrm{D}_{6}\right): \delta 159.2,146.5$, 138.2, 130.5, 126.7, 122.1, 120.8, 120.5, 117.1, 2.4. ${ }^{29} \mathrm{Si}$ NMR $\left(59.6 \mathrm{MHz}, \mathrm{C}_{6} \mathrm{D}_{6}\right): \delta 3.11$. Anal. Calcd for $\mathrm{C}_{22} \mathrm{H}_{29} \mathrm{BiN}_{2} \mathrm{OSi}_{2}$ : C, 43.85; H, 4.85; N, 4.65. Found: C, 43.65; H, 4.91; N, 4.65 .

\subsubsection{Synthesis of 1,8-C $\mathrm{C}_{10} \mathrm{H}_{6}\left(\mathrm{NSiMe}_{3}\right)_{2} \mathrm{BiNH}_{2}(18)$}

Dry ammonia gas was bubbled through the solution of $\mathbf{1}(0.6 \mathrm{~g}, 1.1 \mathrm{mmol})$ in $n$-hexane $(40 \mathrm{~mL})$ for $15 \mathrm{~min}$ at room temperature. After that the solvent was removed in vacuum and the residue was extracted with cold $n$-pentane $(30 \mathrm{~mL})$. The solvent was removed under reduced pressure to yield $0.41 \mathrm{~g}(71 \%)$ of compound $\mathbf{1 8}$ as a colorless oil. ${ }^{1} \mathrm{H}$ NMR (500.13 $\left.\mathrm{MHz}, \mathrm{C}_{6} \mathrm{D}_{6}\right): \delta 7.28-7.33(\mathrm{~m}, 2 \mathrm{H}), 7.17-7.20(\mathrm{~m}, 2 \mathrm{H}), 6.68-6.72(\mathrm{~m}, 2 \mathrm{H}), 5.38(\mathrm{~s}, 2 \mathrm{H}), 0.16(\mathrm{~s}$, 18H). ${ }^{13} \mathrm{C}$ NMR $\left(125.8 \mathrm{MHz}, \mathrm{C}_{6} \mathrm{D}_{6}\right): \delta 144.5,138.1,125.9,121.1,116.1,-0.05 .{ }^{29} \mathrm{Si} \mathrm{NMR}$ $\left(59.6 \mathrm{MHz}, \mathrm{C}_{6} \mathrm{D}_{6}\right): \delta 3.38$.

\subsubsection{Synthesis of $\left[1,8-\mathrm{C}_{10} \mathrm{H}_{6}\left(\mathrm{NSiMe}_{3}\right)_{2} \mathrm{Bi}\right]_{2} \mathrm{~S}(19)$}

$n$-Hexane $(50 \mathrm{~mL})$ was added to the mixture of $\mathbf{1}(0.41 \mathrm{~g}, 0.75 \mathrm{mmol})$ and sulfur $(0.024 \mathrm{~g}$, $0.75 \mathrm{mmol}$ ) at room temperature and stirred for 2 days. After filtration, the resulting solution concentrated and stored at $-30{ }^{\circ} \mathrm{C}$ in a freezer to obtain yellow crystals. Yield: $0.48 \mathrm{~g}(61 \%)$; Mp $130{ }^{\circ} \mathrm{C} .{ }^{1} \mathrm{H}$ NMR $\left(500.13 \mathrm{MHz}, \mathrm{C}_{6} \mathrm{D}_{6}\right): \delta 7.11-7.44(\mathrm{~m}, 10 \mathrm{H}), 6.68-6.72(\mathrm{~m}, 2 \mathrm{H}), 0.18(\mathrm{~s}$, 
36H). ${ }^{13} \mathrm{C}$ NMR $\left(125.8 \mathrm{MHz}, \mathrm{C}_{6} \mathrm{D}_{6}\right): \delta 149.3,144.5,138.2,132.8,125.9,121.2,120,116.6$,

116.1, 3.06. ${ }^{29} \mathrm{Si}$ NMR (59.6 MHz, $\left.\mathrm{C}_{6} \mathrm{D}_{6}\right): \delta 2.86$.

\subsubsection{Synthesis of $\left[1,8-\mathrm{C}_{10} \mathrm{H}_{6}\left(\mathrm{NSiMe}_{3}\right)_{2} \mathrm{Bi}\right]_{2}(20)$}

The $n$-hexane solution $(30 \mathrm{~mL})$ of $\mathbf{1}(1.0 \mathrm{~g}, 1.8 \mathrm{mmol})$ was added to a $n$-hexane solution $(20 \mathrm{~mL})$ of $\mathrm{PhSiH}_{3}(0.2 \mathrm{~g}, 1.85 \mathrm{mmol})$ at $-30{ }^{\circ} \mathrm{C}$. The reaction mixture was warmed to room temperature and stirred for additionally $12 \mathrm{~h}$. Then the mixture was concentrated and stored at $-30{ }^{\circ} \mathrm{C}$ in a freezer to obtain red crystals of 20. Yield (1.1g 60\%); Mp $245{ }^{\circ} \mathrm{C} ;{ }^{1} \mathrm{H}$ NMR $\left(500.13 \mathrm{MHz}, \mathrm{C}_{6} \mathrm{D}_{6}\right): \delta 7.13-7.22(\mathrm{~m}, 12 \mathrm{H}), 0.15(\mathrm{~s}, 36 \mathrm{H}) .{ }^{13} \mathrm{C} \mathrm{NMR}\left(125.8 \mathrm{MHz}, \mathrm{C}_{6} \mathrm{D}_{6}\right): \delta$ 155.7, 138.4, 137.1, 124.9, 120.4, 115.3, 3.7. $\left.{ }^{29} \mathrm{Si} \mathrm{NMR} \mathrm{(59.6} \mathrm{MHz,} \mathrm{C}_{6} \mathrm{D}_{6}\right): \delta$ 6.69. Anal. Calcd for $\mathrm{C}_{32} \mathrm{H}_{48} \mathrm{Bi}_{2} \mathrm{~N}_{4} \mathrm{Si}_{4}:$ C, 37.72; H, 4.75; N, 5.50. Found: C, 37.66; H, 4.48; N, 5.58.

\subsubsection{Synthesis of $\mathrm{LiPh}_{2} \mathrm{P}\left(\mathrm{NSiMe}_{3}\right)_{2}$ (22)}

To a solution of $21(3.0 \mathrm{~g}, 8.33 \mathrm{mmol})$ in toluene $(80 \mathrm{~mL})$ at $-78{ }^{\circ} \mathrm{C}$ was added $n \mathrm{BuLi}$ (2.5 M, $3.4 \mathrm{~mL}, 8.5 \mathrm{mmol})$. The mixture was warmed to room temperature and stirred over night. Toluene was removed under reduced pressure and the product was recrystallized from a mixture of toluene and $n$-hexane. $\left[\mathrm{LiPh}_{2} \mathrm{P}\left(\mathrm{NSiMe}_{3}\right)_{2}\right]$ formed colorless crystals. Yield $(0.84 \mathrm{~g}$, $83 \%)$, whose spectral data agreed with those reported in literature. ${ }^{6} \mathrm{H}$ NMR $\left(200 \mathrm{MHz}, \mathrm{C}_{6} \mathrm{D}_{6}\right.$, $298 \mathrm{~K}): \delta 0.12$ (s, 18H, Si-Me), 7.61-7.80 (m, 4H, o-Ar), 6.98-7.07 (m, 6H, p-/m-Ar). ${ }^{31} \mathrm{P}$ NMR (121.50 MHz, $\left.\mathrm{C}_{6} \mathrm{D}_{6}, 298 \mathrm{~K}\right): \delta 7.4$.

\subsubsection{Synthesis of $\mathrm{Ph}_{2} \mathrm{P}\left(\mathrm{NSiMe}_{3}\right)_{2} \mathrm{AlCl}_{2}(23)$}

A toluene solution of freshly prepared $22(1.0 \mathrm{~g}, 2.73 \mathrm{mmol})$ was added drop by drop to a cold suspension of freshly sublimed $\mathrm{AlCl}_{3}(0.36 \mathrm{~g}, 2.73 \mathrm{mmol})$ in toluene at $-78{ }^{\circ} \mathrm{C}$. The temperature was raised to $0{ }^{\circ} \mathrm{C}$ and stirred for $1 \mathrm{~h}$ and stirring was continued for $3 \mathrm{~h}$. The solution was allowed to attain room temperature and stirring was continued for $12 \mathrm{~h}$. Then the 
mixture was filtered, and the concentrated solution was stored in a freezer at $-30{ }^{\circ} \mathrm{C}$ to obtain colorless crystals. Yield (0.76g 61\%); Mp $135{ }^{\circ} \mathrm{C}$ (dec); ${ }^{1} \mathrm{H}$ NMR (200 MHz, $\left.\mathrm{C}_{6} \mathrm{D}_{6}, 298 \mathrm{~K}\right): \delta$ -0.2 (s, 18H, $\left.\mathrm{SiCH}_{3}\right), 7.65-7.81$ (m, 4H, o-Ar), 6.95-7.07 (m, 6H, p-/m-Ar). ${ }^{13} \mathrm{C}$ NMR (125.76 $\left.\mathrm{MHz}, \mathrm{C}_{6} \mathrm{D}_{6}, 298 \mathrm{~K}\right): \delta 1.91,1.93,132.3-127.4 .{ }^{31} \mathrm{P} \mathrm{NMR}\left(121.50 \mathrm{MHz}, \mathrm{C}_{6} \mathrm{D}_{6}\right): \delta 37.8$.

\subsubsection{Synthesis of $\mathrm{Ph}_{2} \mathrm{P}\left(\mathrm{NSiMe}_{3}\right)_{2} \mathrm{AlClMe}$ (24)}

$\mathrm{AlMeCl}_{2}(1.0 \mathrm{M}$ in $n$-hexane, $1.4 \mathrm{~mL}, 1.4 \mathrm{mmol})$ was added drop by drop to the solution of freshly prepared $22(0.5 \mathrm{~g}, 1.36 \mathrm{mmol})$ in toluene $(70 \mathrm{~mL})$ at $-78^{\circ} \mathrm{C}$. The mixture was stirred at $-78{ }^{\circ} \mathrm{C}$ for $1 \mathrm{~h}$ and then the temperature was slowly raised to $0{ }^{\circ} \mathrm{C}$ and stirring was continued for $3 \mathrm{~h}$. After that the solution was allowed to attain room temperature and stirring was continued for $12 \mathrm{~h}$. Then the mixture was extracted with $n$-hexane $(70 \mathrm{~mL})$, and the concentrated solution was stored in a freezer at $-30{ }^{\circ} \mathrm{C}$ to obtain colorless crystals. Yield (0.41g 68\%); $\mathrm{Mp} 135{ }^{\circ} \mathrm{C} ;{ }^{1} \mathrm{H}$ NMR (200 MHz, $\left.\mathrm{C}_{6} \mathrm{D}_{6}, 298 \mathrm{~K}\right): \delta-0.03$ (s, 18H, Si-Me), 0.04 (s, 3H, Al-Me), 7.65-7.85 (m, 4H, o-Ar), 6.92-7.07 (m, 6H, p-/m-Ar). ${ }^{13} \mathrm{C}$ NMR (125.76 MHz, $\left.\mathrm{C}_{6} \mathrm{D}_{6}, 298 \mathrm{~K}\right): \delta-0.69,1.71,1.66,131.6-129.2 .{ }^{31} \mathrm{P} \mathrm{NMR}\left(121.50 \mathrm{MHz}, \mathrm{C}_{6} \mathrm{D}_{6}, 298 \mathrm{~K}\right): \delta 33.2$.

${ }^{29} \mathrm{Si}$ NMR (59.6 MHz, $\left.\mathrm{C}_{6} \mathrm{D}_{6}, 298 \mathrm{~K}\right): \delta-0.31,-0.34$. Anal. Calcd for $\mathrm{C}_{19} \mathrm{H}_{31} \mathrm{AlClN}_{2} \mathrm{PSi}_{2}: \mathrm{C}$, 52.22; H, 7.15; N, 6.41. Found C, 52.54; H, 7.15; N, 6.21.

\subsubsection{Synthesis of $\left[\mathrm{Ph}_{2} \mathrm{P}\left(\mathrm{NSiMe}_{3}\right)_{2}\right]_{2} \mathrm{AlH}(25)$}

The $n$-hexane solution $(30 \mathrm{~mL})$ of $21(1.0 \mathrm{~g}, 2.7 \mathrm{mmol})$ was added drop by drop to a cold suspension of freshly sublimed $\mathrm{AlH}_{3} \cdot \mathrm{NMe}_{3}$ in THF $(30 \mathrm{~mL}),(0.12 \mathrm{~g}, 1.39 \mathrm{mmol})$ at $-78{ }^{\circ} \mathrm{C}$. The mixture was stirred at $-30{ }^{\circ} \mathrm{C}$ for $1 \mathrm{~h}$ and then the temperature was slowly raised to $0{ }^{\circ} \mathrm{C}$ and the stirring was continued for $3 \mathrm{~h}$. Then the solution was allowed to attain room temperature under stirring for $12 \mathrm{~h}$. Then the mixture was concentrated and stored in a freezer at $-30{ }^{\circ} \mathrm{C}$ to obtain colorless crystals. Yield: $(0.64 \mathrm{~g} 61 \%)$; Mp $107{ }^{\circ} \mathrm{C}(\mathrm{dec}) ;{ }^{1} \mathrm{H}$ NMR $(200$ 
$\left.\mathrm{MHz}, \mathrm{CDCl}_{3}, 298 \mathrm{~K}\right): \delta-0.22$ (s, 18H, Si-Me), -0.13 (s, 18H, Si-Me), 5.1 (very br, $1 \mathrm{H}, \mathrm{Al}-\mathrm{H}$ ), 7.78-7.92 (m, 4H, o-Ar), 7.45-7.59 (m, 6H, p-/m-Ar). ${ }^{13} \mathrm{C}$ NMR (125.76 MHz, $\left.\mathrm{C}_{6} \mathrm{D}_{6}, 298 \mathrm{~K}\right)$ : $\delta 1.52,1.56,3.75,3.80,133.1-131.2 .{ }^{31} \mathrm{P}$ NMR $\left(121.50 \mathrm{MHz}, \mathrm{C}_{6} \mathrm{D}_{6}, 298 \mathrm{~K}\right): \delta 29.2,34.6 .{ }^{29} \mathrm{Si}$ NMR (59.6 MHz, $\left.\mathrm{C}_{6} \mathrm{D}_{6}, 298 \mathrm{~K}\right): \delta-4.15,-4.22 . \mathrm{IR}\left(\mathrm{cm}^{-1}\right): \widetilde{\boldsymbol{v}}(\mathrm{AlH})$ 1853. Anal. Calcd for $\mathrm{C}_{37} \mathrm{H}_{60} \mathrm{AlN}_{4} \mathrm{P}_{2} \mathrm{Si}_{4}: \mathrm{C}, 58.31 ; \mathrm{H}, 7.93 ; \mathrm{N}, 7.35$. Found C, 57.94; H, 7.83; N, 7.21.

\subsubsection{Synthesis of $\mathrm{Ph}_{2} \mathrm{P}\left(\mathrm{NSiMe}_{3}\right)_{2} \mathrm{AlEt}_{2}$ (26)}

$\mathrm{AlEt}_{3}(2.2 \mathrm{~mL}, 2.2 \mathrm{mmol})$ was added to a $n$-hexane $(50 \mathrm{~mL})$ solution of $21(0.8 \mathrm{~g}, 2.2$ mmol) at $-78{ }^{\circ} \mathrm{C}$. The mixture was stirred for $1 \mathrm{~h}$ at this temperature and then was allowed to attain room temperature and stirring was continued for $12 \mathrm{~h}$. The mixture was concentrated and stored in a freezer at $-30{ }^{\circ} \mathrm{C}$ to give white microcrystalline solid. Yield: $(0.86 \mathrm{~g}, 88 \%) ;{ }^{1} \mathrm{H}$ NMR (500 MHz, $\mathrm{C}_{6} \mathrm{D}_{6}, 298 \mathrm{~K}$ ): $\delta-0.05$ (s, 18H, Si-Me), 0.45 (q, 4H, $\mathrm{CH}_{2}$ ), 1.52 (t, 6H, $\mathrm{CH}_{3}$ ), 7.71-7.81 (m, 4H, o-Ar), 6.97-7.11 (m, 6H, p-/m-Ar). ${ }^{13} \mathrm{C}$ NMR (125.8 MHz, $\left.\mathrm{C}_{6} \mathrm{D}_{6}, 298 \mathrm{~K}\right): \delta$ 1.99, 2.04, 10.4, 134.5-131.9. ${ }^{31} \mathrm{P}$ NMR (121.50 MHz, $\left.\mathrm{C}_{6} \mathrm{D}_{6}, 298 \mathrm{~K}\right): \delta 30.3 .{ }^{29} \mathrm{Si}$ NMR (59.6 $\left.\mathrm{MHz}, \mathrm{C}_{6} \mathrm{D}_{6}, 298 \mathrm{~K}\right): \delta-2.61,-2.54$.

\subsubsection{Synthesis of $\mathrm{Ph}_{2} \mathrm{P}\left(\mathrm{NSiMe}_{3}\right)_{2} \mathrm{Al}\left(\mathrm{NMe}_{2}\right)_{2}$ (27)}

$n$-Hexane $(30 \mathrm{~mL})$ solution of $21(0.9 \mathrm{~g}, 2.5 \mathrm{mmol})$ was added to $\left[\mathrm{Al}\left(\mathrm{NMe}_{2}\right)_{3}\right]_{2}(0.4 \mathrm{~g}$, $1.25 \mathrm{mmol})$ in $n$-hexane $(20 \mathrm{~mL})$, and then heated under reflux for $6 \mathrm{~h}$. The mixture was cooled to room temperature, concentrated and stored in a freezer at $-30{ }^{\circ} \mathrm{C}$ to obtain a colorless microcrystalline solid. Yield: (0.69 g, $58 \%$ ); $\mathrm{Mp} 156{ }^{\circ} \mathrm{C} ;{ }^{1} \mathrm{H}$ NMR $\left(500 \mathrm{MHz}, \mathrm{C}_{6} \mathrm{D}_{6}\right.$, $298 \mathrm{~K}): \delta 0.024$ (s, 18H, Si-Me), $3.06\left(\mathrm{~s}, 12 \mathrm{H}, \mathrm{CH}_{3}\right), 7.73-7.83(\mathrm{~m}, 4 \mathrm{H}, o-\mathrm{Ar}), 7.03-7.08$ (m,

$6 \mathrm{H}, \mathrm{p}-/ \mathrm{m}-\mathrm{Ar}) .{ }^{13} \mathrm{C}$ NMR $\left(125.8 \mathrm{MHz}, \mathrm{C}_{6} \mathrm{D}_{6}, 298 \mathrm{~K}\right): \delta 1.86,1.92,41.8,134.3-132.0 .{ }^{31} \mathrm{P} \mathrm{NMR}$ $\left(121.50 \mathrm{MHz}, \mathrm{C}_{6} \mathrm{D}_{6}, 298 \mathrm{~K}\right): \delta 28.6 .{ }^{29} \mathrm{Si} \mathrm{NMR}\left(59.6 \mathrm{MHz}, \mathrm{C}_{6} \mathrm{D}_{6}, 298 \mathrm{~K}\right): \delta-2.67,-2.72$. 
Anal. Calcd for $\mathrm{C}_{22} \mathrm{H}_{40} \mathrm{AlN}_{4} \mathrm{PSi}_{2}$ : C, 55.66; H, 8.49; N, 11.80. Found C, 55.11; H, 8.63; N, 11.94. 


\section{Handling and Disposal of Solvents and Residual Waste}

1 The recovered solvents were distilled or condensed into a cold-trap under vacuum and collected in halogen-free or halogen-containing solvent containers, and stored for disposal.

2 Used NMR solvents were classified into halogen-free and halogen-containing solvents and were disposed as halogen containing wastes, respectively.

3 Drying agents such as $\mathrm{KOH}, \mathrm{CaCl}_{2}$ and $\mathrm{P}_{4} \mathrm{O}_{10}$ were hydrolyzed and disposed as acid or base wastes.

4 Whenever possible, sodium metal used for drying solvents was collected for recycling. ${ }^{157}$ The non-reusable sodium metal was carefully hydrolyzed in cold ethanol and poured into the base-bath used for cleaning glassware.

5 Ethanol and acetone used for cold-baths (with solid $\mathrm{CO}_{2}$ or liquid $\mathrm{N}_{2}$ ) were subsequently used for cleaning glassware.

6 The acid-bath used for cleaning glassware was neutralized with $\mathrm{Na}_{2} \mathrm{CO}_{3}$ and the resulting $\mathrm{NaCl}$ solution was washed-off in the communal water drainage.

7 The residue of the base-bath used for glassware cleaning was poured into container for base wastes.

Amounts of various types of disposable wastes generated during the work:

Heavy elements containing wastes $3 \mathrm{~L}$

Halogen-containing solvent wastes $8 \mathrm{~L}$

Halogen-free solvent wastes $40 \mathrm{~L}$

Acid wastes $20 \mathrm{~L}$

Base wastes $30 \mathrm{~L}$ 


\section{References}

(1) R. K. Grasselli, J. D. Burrington, Adv. Catal. 1981, 30, 133-163.

(2) a) S. Shimada, O. Yamazaki, T. Tanaka, M. L. N. Rao, Y. Suzuki, M. Tanaka, Angew. Chem. 2003, 115, 1889-1892. Angew. Chem., Int. Edit. 2003, 42, 1845-1848.

b) G. O. Doak, L. D. Freedman, Organometallic Compounds of Arsenic, Antimony, and Bismuth; Wiley-Interscience: New York, 1970. c) H. Gaspard-Iloughmane, C. Le Roux, Eur. J. Org. Chem. 2004, 2517- 2532.

(3) R. Dagani, Chem. Eng. News 1987, 65, 41-49.

(4) M. Vehkamäki, T. Hatanpää, M. Ritala, M. Leskelä, J . Mater. Chem. 2004, 14, 31913197.

(5) M. Vehkamäki, T. Hatanpää, M. Kemell, M. Ritala, M. Leskelä, Chem. Mater. 2006, $18,3883-3888$.

(6) W. Clegg, N. A. Compton, R. J. Errington, G. A. Fisher, M. E. Green, D. C. R. Hockless, N. C. Norman, Inorg. Chem. 1991, 30, 4680-4682.

(7) F. Ando, T. Hayashi, K. Ohashi, J. Koketsu, J. Inorg. Nucl. Chem. 1975, 37, 20112013.

(8) S. C. James, N. C. Norman, A. G. Orpen, M. J. Quayle, U. Weckenmann, J. Chem. Soc., Dalton Trans. 1996, 4159-4161.

(9) U. Wirringa, H. W. Roesky, M. Noltemeyer, H.-G. Schmidt, Inorg. Chem. 1994, 33, 4607-4608.

(10) N. Burford, C. L. B. Macdonald, K. N. Robertson, T. S. Cameron, Inorg. Chem. 1996, $35,4013-4016$.

(11) O. J.Scherer, P. Hornig, M. Schmidt, J. Organomet. Chem. 1966, 6, 259-264.

(12) M. J. S. Gynane, A. Hudson, M. F. Lappert, P. P. Power, H. Goldwhite, J. Chem. Soc. Dalton Trans. 1980, 2428-2433. 
(13) M. Veith, B. Bertsch, Z. Anorg. Allg. Chem. 1988, 557, 7-22.

(14) a) C. M. Kozak, P. Mountford, Angew. Chem. 2004, 116, 1206-1209; Angew. Chem., Int. Ed. 2004, 43, 1186-1189. b) R. Pryadun, D. Sukumaran, R. Bogadi, J. D. Atwood, J. Am. Chem. Soc. 2004, 126, 12414-12420. c) Y. Ohki, M. D. Fryzuk, Angew. Chem. 2007, 119, 3242-3245; Angew. Chem., Int. Ed. 2007, 46, 3180-3183.

(15) T. A. George, M. F. Lappert, J. Organomet. Chem. 1968, 14, 327-337.

(16) R. H. Cragg, M. F. Lappert, J. Chem. Soc. A 1966, 82-85

(17) P. Zhao, C. Krug, J. F. Hartwig, J. Am. Chem. Soc. 2005, 127, 12066-12073.

(18) E. Katayev, Y. Li, A. L. Odom, Chem. Commun. 2002, 838-839.

(19) C. G.Young, Coord. Chem. Rev. 1989, 96, 89-251.

(20) G. D. Lawrence, D. T. Sawyer, Coord. Chem. Rev. 1978, 27, 173-193.

(21) W. M. Coleman, L. T. Taylor, Coord. Chem. Rev. 1980, 32, 1-31.

(22) D. W. Stephan, Coord. Chem. Rev. 1989, 95, 41-107.

(23) U. Casellato, P. A. Vigato, Coord. Chem. Rev. 1977, 23, 31-117.

(24) K. Mochizuki, M. Tsutsumi, Y. Yamaji, Inorg. Chim. Acta. 1992, 191, 35-37.

(25) I. Murase, K. Hamada, S. Kida, Inorg. Chim. Acta. 1981, 54, L171-L173.

(26) J. P. Collman, J. E. Hutchison, M. A. Lopez, A. Tabard, R. Guilard, W. K. Seok, J. A. Ibers, M. L'Her, J. Am. Chem. Soc. 1992, 114, 9869-9877.

(27) K. D. Karlin, Y. Gultneh, J. P. Hutchinson, J. Zubieta, J. Am. Chem.Soc. 1982, 104, $5240-5242$.

(28) J. -P. Costes, J. -F. Serra, F. Dahan, J. P. Laurent, Inorg. Chem. 1986, 25, 2790-2795 and references cited therein.

(29) N. Kitajima, T. Koda, S. Hasimoto, T. Kitagawa, Y. Moro-oka, J. Chem. Soc., Chem. Commun. 1988, 151-152. 
(30) R. L. Lintvedt, M. D. Glick, B. K. Tomlonovic, D. P. Gavel, Inorg. Chem. 1976, $15,1646-1654$.

(31) N. Kitajima, N. Tamura, M. Tanaka, Y. Moro-oka, Y. Inorg. Chem. 1992, 31, 33423343.

(32) E. J. Larson, V. L. Pecoraro, J. Am. Chem. Soc. 1991, 113, 3810-3818.

(33) R. Das, K. Nag, Inorg. Chem. 1991, 30, 2833-2835.

(34) W. B. Tolman, S. Liu, J. G. Bentsen, S. J. Lippard, J. Am. Chem. Soc. 1991, 113, 152164.

(35) J. B. Vincent, J. C. Huffman, G. Christou, Q. Li, M. A. Nanny, D. N. Hendrickson, R. H. Fong, R. H. Fish, J. Am. Chem. Soc. 1988, 110, 6898-6900.

(36) W. B. Tolman, A. Bino, S. J. Lippard, J. Am. Chem. Soc. 1989, 111, 8522-8523.

(37) L. G. Hubert-Pfalzgraf, Inorg. Chem. Comm. 2003, 6, 102-120.

(38) J. Gopalakrishnan, Chem. Mater. 1995, 7, 1265-1275.

(39) T. D. Tilly, J. Mol. Catal. A: Chemical 2002, 182-183, 17-24.

(40) P. Hodge, S. C. James, N. C. Norman, A. G. Orpen, J. Chem. Soc.,Dalton Trans. 1998, 4049-4054 and references therein.

(41) S. Parola, R. Papiernik, L. G. Hubert-Pfalzgraf, C. Bois, J. Chem. Soc., Dalton Trans. 1998, 737-739.

(42) a) T. Ono, N. Ogata, R. L. Kuczkowski, J. Catal. 1998, 175, 185-193. b) R. K. Grasselli, J. D. Burrington, Ind. Eng. Chem. Prod. Res. Dev. 1984, 23, 393-404.

(43) a) N. Zhang, Z. Ding, Y. Wu, M. Salomon, IEEE Trans. Nucl. Science, 1990, 37, 216-219. b) C. Li, T. Yoshino, Appl. Opt. 2002, 41, 5391-5397.

(44) C. K. Lee, B. H. Bay, A. R. West, J. Mater. Chem. 1996, 6, 331-335.

(45) H. J. Breunig, L. Königsmann, E. Lork, M. Nema, N. Philipp, C. Silvestru, A. Soran, R. A. Varga, R. Wagner, Dalton Trans. 2008, 1831-1842.

(46) G. Balazs, H. J. Breunig, E. Lork, Organometallics 2002, 21, 2584-2586. 
(47) A. J. Ashe, III; E. G. Ludwig, Jr, J. Oleksyszyn, Organometallics 1983, 2, 1859- 1866.

(48) F. Calderazzo, A. Morvillo, G. Pelizzi, R. Poli, F. Ungari, Inorg. Chem. 1988, 27, $3730-3733$.

(49) S. Hoppe, K. H. Whitmire, Organometallics 1998, 17, 1347-1354.

(50) L. Balazs, H. J. Breunig, E. Lork, C. Silvestru, Eur. J. Inorg. Chem. 2003, 1361- 1365.

(51) L. Balazs, H. J. Breunig, E. Lork, A. Soran, C. Silvestru, Inorg. Chem. 2006, 45, 2341-2346.

(52) M. Wieber, I. Z. Sauer, Z. Naturforsch. 1987, 42B, 695-698.

(53) a) L. Balazs, H. J. Breunig, Coord. Chem. Rev. 2004, 248, 603-621. b) H. J. Breunig, Z. Anorg. Allg. Chem. 2005, 631, 621-631.

(54) H. Suzuki, Y. Matano, Organobismuth Chemistry, Elsevier, 2001.

(55) A. J. Ashe, III, J. W. Kampf, D. B. Puranik, S. M. Al-Taweel, Organometallics 1992, $11,2743-2745$.

(56) H. J. Breunig, R. Rösler, E. Lork, Angew. Chem. 1998, 110, 3361-3363; Angew. Chem., Int. Ed. Engl. 1998, 37, 3175-3177.

(57) D. C. Bradley, Chem. Rev. 1989, 89, 1317-1322.

(58) See for example: G. A. Olah, S. Kobayashi, M. Tashiro, J. Am. Chem. Soc. 1972, 94, 7448-7461.

(59) H. C. Brown, C. J. Shoaf, J. Am. Chem. Soc. 1964, 86, 1079-1085.

(60) E. Wiberg, E. Amberger, Hydrides of the Elements of Main Group I-IV, Elsevier, New York, 1971, Ch. 5.

(61) A. Murphy, Nature 1991, 350, 223-225.

(62) a) A. R. Barron, Adv. Mater. Opti. Electron. 1995, 5, 245-258. b) J. L. Atwood in Coordination Chemistry of Aluminium (Ed.: G. H. Robinson), VCH, New Yourk, 1993, pp. 197-232. c) H. Sinn, W. Kaminsky, H. J. Vollmer, R. Woldt, Angew. 
Chem. 1980, 92, 396-402; Angew. Chem,. Int. Ed. Engl. 1980, 19, 390-392. d) H. Sinn, W. Kaminsky, Adv. Organomet. Chem. 1980, 18, 99-149.

(63) R. G. Gordon, D. M. Hoffman, U. Riaz, J. Mater. Res. 1991, 6, 5-7.

(64) R. G. Gordon, U. Riaz, D. M. Hoffman, J. Mater. Res. 1992, 7, 1679-1684.

(65) Y. Takahashi, K. Yamashita, S. Motojima, K. Sugiyama, Surf. Sci. 1979, 86, 238-245.

(66) K. L. Ho, K. F. Jensen, J. W. Hwang, W. L. Gladfelter, J. F. Evans, J. Cryst. Growth 1991, 107, 376-380.

(67) K. L. Ho, D. C. Boyd, K. F. Jensen, S. A. Hanson, W. L. Gladfelter, J. F. Evans, Mater. Res. Symp. Proc. 1990, 132, 162.

(68) R. K. Schulze, D. R. Mantell, W. L. Gladfelter, J. F. Evans, J. Vac. Sci. Technol. A 1988, 6, 2162-2163.

(69) L. V. Interrante, W. Lee, M. McConnell, N. Lewis, E. Hall, J. Electrochem. Soc. 1989, $136,472-478$.

(70) F. C. Sauls, L. V. Interrante, Coord. Chem. Rev. 1993, 128, 193-207.

(71) K. Ziegler, F. Krupp, K. Zosel, Angew. Chem. 1955, 67, 425.

(72) D. A. Neumayer, J. G. Ekerdt, Chem. Mater. 1996, 8, 9-25, and references cited therein.

(73) D. C. Boyd, R. T. Haasch, P. R. Mantell, R. K. Schulze, J. F. Evans, W. L. Gladfelter, Chem. Mater. 1989, 1, 119-124.

(74) A. Rabenau in: Compounds Semiconductors (Eds.: R. K. Willardson, H. L. Goerring), Reinhold Publishing Corp., New York, USA, 1962, Vol. 1, Chapter 19, 174.

(75) a) L.V. Interrante, L.E. Carpenter, C. Whitmarsch, W. Lee, G. A. Slack, Mater. Res. Soc. Symp. Proc 1986, 73, 359-366. b) Chemistry of Aluminum, Gallium, Indium and Thallium (Ed.: A. J. Downs), Blackie, Glasgow, 1993. c) A. C. Jones, P. O'Brien in CVD of Compound Semiconductors, VCH, Weinheim, 1997 
(76) a) G. H. Robinson, Ed., Coordination Chemistry of Aluminum, VCH Publishers; Weinheim, FRG, 1994, pp.1-56; (b) G. H. Robinson, Ed., Coordination Chemistry of Aluminum, VCH Publishers; Weinheim, FRG, 1994, pp.57-84.

(77) a) L.V. Interrante, G.A. Sigel, M. Garbauskas, C. Hejna, G.A. Slack, Inorg. Chem. 1989, 28, 252-257. b) W. Rockensüss, H. W. Roesky, Adv. Mater. 1993, 5, 443-445.

(78) D. C. Bradley, I. S. Harding, I. A. Maria, M. Motevalli, J. Chem. Soc., Dalton Trans. 1997, 2969-2979.

(79) K. J. Alford, K. Gosling, J. D. Smith, J. Chem. Soc., Dalton Trans. 1972, 20, $2203-$ 2208.

(80) N. Wiberg, W. Baumeister, P. Zhan, J. Organomet. Chem. 1972, 36, 267-276.

(81) a) T. Akakibara, T. Hirabayashi, Y. Ishi, J. Organomet. Chem. 1972, 46, 231-242.

(82) C. Cui, H. W. Roesky, M. Noltemeyer, H.-G. Schmidt, Organometallics 1999, 18, $5120-5123$.

(83) Z. Yang, X. Ma, R. B. Oswald, H. W. Roesky, M. Noltemeyer, J. Am. Chem. Soc. 2006, 128, 12406-12407.

(84) See for example: Z. Yang, H. Zhu, X. Ma, J. Chai, H. W. Roesky, C. He, H.-G. Schmidt, M. Noltemeyer, Inorg. Chem. 2006, 45, 1823-1827.

(85) J. D. Scollard, D. H. McConville, J. Am. Chem. Soc. 1996, 118, 10008-10009.

(86) B. Tsuie, D. C. Swenson, R. F. Jordan, J. L. Petersen, Organometallics 1997, 16, 1392-1400.

(87) L. Grocholl, V. Huch, L. Stahl, R. J. Staples, P. Steinhart, A. Johnson, Inorg. Chem. 1997, 36, 4451-4457.

(88) C. H. Galka, D. J. M. Trösch, I. Rüdenauer, L. H. Gade, I. Scowen, M. McPartlin, Inorg. Chem. 2000, 39, 4615-4620

(89) F. Ando, Y. Kohmura, J. Koketsu, Bull. Chem. Soc. Jpn. 1987, 60, 1564-1566. 
(90) A. Jana, H. W. Roesky, C. Schulzke, A. Döring, Angew. Chem. 2009, 121, 1126-1129; Angew. Chem., Int. Ed. 2009, 48, 1106-1109.

(91) U. N. Nehete, H. W. Roesky, V. Jancik, A. Pal, J. Magull, Inorg. Chim. Acta 2007, $360,1248-1257$.

(92) T. A. Hanna, G. Keitany, C. Ibarra, R. D. Sommer, A. L. Rheingold, Polyhedron 2001, 20, 2451-2455.

(93) O. M. Uy, J. Drowart, Trans. Faraday Soc. 1969, 65, 3221-3230.

(94) N. C. Norman, Chemistry of Arsenic, Antimony, and Bismuth, Blackie Academic \& Professional, London, 1998.

(95) S. Shimada, O. Yamazaki, T. Tanaka, S. Yohichi, M. Tanaka, J. Organomet. Chem. 2004, 689, 3012-3023.

(96) G. G. Briand, N. Burford, M. D. Eelman, T. S. Cameron, K. N. Robertson, Inorg. Chem. 2003, 42, 3136-3141.

(97) J. W. Pell, W. C. Davis, H. C. zur Loye, Inorg. Chem. 1996, 35, 5754-5755.

(98) a) M. Mehring, Coord. Chem. Rev. 2007, 251, 974-1006. b) D. Meendoza-Espinosa, T. A. Hanna, Inorg. Chem. 2009, 48, 7452-7456. c) C. Knispel, C. Limberg, M. Mehring, Organometallics 2009, 28, 646-651. d) V. Stavila, J. H. Thurston, K. H. Whitmire, Inorg. Chem. 2009, 48, 6945-6951. e) B. Li, H. Zhang, L. Huynh, C. Diverchy, S. Hermans, M. Devillers, E. V. Dikarev, Inorg. Chem. 2009, 48, 61526158.

(99) a) M. Hunger, C. Limberg, P. Kircher, Angew. Chem. 1999, 111, 1171-1174; Angew. Chem., Int. Ed. 1999, 38, 1105-1108. b) S. Roggan, C. Limberg, B. Zimmer, M. Brandt, Angew. Chem. 2004, 116, 2906-2910; Angew. Chem., Int. Ed. 2004, 43, 28462849 .

(100) J. H. Thurston, D. Trahan, T. Ould-Ely, K. H. Whitmire, Inorg. Chem. 2004, 43, 32993305. 
(101) a) P. M. Gurubasavaraj, H. W. Roesky, B. Nekoueishahraki, A. Pal, R. Herbst-Irmer, Inorg. Chem. 2008, 47, 5324-5331. b) S. K. Mandal, P. M. Gurubasavaraj, H. W. Roesky, R. B. Oswald, J. Magull, A. Ringe, Inorg. Chem. 2007, 46, 7594-7600. c) P. M. Gurubasavaraj, S. K. Mandal, H. W. Roesky, R. B. Oswald, A. Pal, M. Noltemeyer, Inorg. Chem. 2007, 46, 1056-1061. d) G. B. Nikiforov, H. W. Roesky, T. Schulz, D. Stalke, M. Witt, Inorg. Chem. 2008, 47, 6435-6443.

(102) H. Gornitzka, D. Stalke, Organometallics 1994, 13, 4398-4405.

(103) S. Singh, A. Pal, H. W. Roesky, R. Herbst-Irmer, Eur. J. Inorg. Chem. 2006, 40294032 .

(104) L. W. Pineda, V. Jancik, H. W. Roesky, R. Herbst-Irmer, Inorg. Chem. 2005, 44, $3537-3540$.

(105) Y. Yang, H. W. Roesky, P. G. Jones, C.-W. So, Z. Zhang, R. Herbst-Irmer, H. Ye, Inorg. Chem. 2007, 46, 10860-10863.

(106) G. Bai, S. Singh, H. W. Roesky, M. Noltemeyer, H.-G. Schmidt, J. Am. Chem. Soc. 2005, 127, 3449-3455.

(107) B. Moraru, G. Kickelbick, U. Schubert, Eur. J. Inorg. Chem. 2001, 1295-1301.

(108) S. Parola, R. Papiernik, L. G. Hubert-Pfalzgraf, S. Jagner, M. Hakansson, J. Chem. Soc., Dalton Trans. 1997, 4631-4635.

(109) S. Roggan, C. Limberg, B. Ziemer, Angew. Chem. 2005, 117, 5393-5397; Angew. Chem., Int. Ed. 2005, 44, 5259- 5262.

(110) K. C. H. Lange, T. M. Klapötke, In The Chemistry of Organic Arsenic, Antimony, and Bismuth Compounds; S. Patai, Ed.; Wiley: New York, 1994; Chapter 8.

(111) K. Li, H. Xu, Z. Xu, M. Zeller and A. D. Hunter, Inorg. Chem. 2005, 44, 8855-8860.

(112) H. Suzuki, T. Ikegami, Y. Matano, Synthesis 1997, 249-267. 
(113) a) Z. Shen, J. Q. Zhang, H. X. Zou, M. M. Yang, Tetrahedron Lett. 1997, 38, 2733. b) S. Repichet, C. Le Roux, J. Dubac, J. R. Desmurs, Eur. J. Org. Chem. 1998, 27432746.

(114) Y. Matano, H. Nomura, Angew. Chem. 2002, 114, 3154-3157; Angew. Chem., Int. Ed. 2002, 41, 3028-3031.

(115) A. P. Soran, C. Silvestru, J. H. Breunig, G. Balazs, J. C. Green, Organometallics 2007, 26, 1196-1203.

(116) L. W. Pineda, V. Jancik, S. Nembenna, H. W. Roesky, Z. Anorg. Allg. Chem. 2007, 633, 2205-2209.

(117) J. Emsley, Die Elemente; Walter de Gruyter: Berlin, 1994.

(118) H. Sitzmann, G. Wolmershäuser, Z. Anorg. Allg. Chem. 1999, 625, 2103-2107.

(119) M. Wieber, I. Sauer, Z. Naturforsch. 1984, 39b, 887-889.

(120) H. J. Breunig, D. Müller, Z. Naturforsch. 1986, 41b, 1129-1132.

(121) H. J. Breunig, K. H. Ebert, R. E. Schulz, M. Wieber, I. Sauer, Z. Naturforsch. 1995, 50b, 735-744.

(122) X.-W. Li, J. Lorberth, K. H. Ebert, W. Massa, S. Wocadlo, J. Organomet. Chem. 1998, 560, 211-215.

(123) H. J. Breunig, I. Ghesner, E. Lork, J. Organomet. Chem. 2002, 664, 130-135.

(124) M. Chovancova, R. Jambor, A. Ruzicka, R. Jirasko, I. Cisarova, L. Dostal, Organometallics 2009, 28, 1934-1941.

(125) F. Calderazzo, R. Poli, G. Pelizzi, J. Chem. Soc., Dalton Trans. 1984, 2365.

(126) O. Mundt, G. Becker, M. Rössler, C. Witthauer, Z. Anorg. Allg. Chem. 1983, 506, 4258.

(127) W. Frank, V. Reiland, G. J. Reiss, Angew. Chem. 1998, 110, 3154-3156; Angew. Chem., Int. Ed. Engl. 1998, 37, 2983-2985. 
(128) See for further bindings modes: P. C. Junk, M. L. Cole, Chem. Commun. 2007, 15791590.

(129) M. Witt, H. W. Roesky, D. Stalke, F. Pauer, T. Henkel, G. M. Sheldrick, J. Chem. Soc., Dalton Trans. 1989, 2173-2177.

(130) A. Recknagel, M. Witt, F. T. Edelmann, J. Organomet. Chem. 1989, 371, C40-C44.

(131) H. Ackermann, O. Bock, U. Müller, K. Dehnicke, Z. Anorg. Allg. Chem. 2000, 626, 1854-1856.

(132) R. Boese, M. Düppmann, W. Kuchen, W. Peters, Z. Anorg. Allg. Chem. 1998, 624, 837-845.

(133) R. Vollmerhaus, R. Tomaszewski, P. Shao, N. J. Taylor, K. J. Wiacek, S. P. Lewis, A. Al-Humydi, S. Collins, Organometallics 2005, 24, 494-507.

(134) a) H. Schmidbaur, K. Schwirten, H.-H. Pickel, Chem. Ber. 1969, 102, 564-567. b) W. Wolfsberger, W. Hager, Z. Anorg. Allg. Chem. 1976, 425, 169-174. c) W. Wolfsberger, W. Hager, Z. Anorg. Allg. Chem. 1977, 433, 241-254.

(135) A. Steiner, D. Stalke, Inorg. Chem. 1993, 32, 1977-1981.

(136) R. Fleischer, D. Stalke, Inorg. Chem. 1997, 36, 2413-2419.

(137) E. Huheey, Inorganic Chemistry, 3rd edn., Harper and Row, New York, 1983.

(138) H. R. Allcock, Phosphorus-Nitrogen Compounds, Academic Press, New York and London, 1972.

(139) N. Kocher, D. Leusser, A. Murso, D. Stalke, Chem. Eur. J. 2004, 10, 3622-3631.

(140) J. F. Bickley, M. C. Copsey, J. C. Jeffery, A. P. Leedham, C. A. Russell, D. Stalke, A. Steiner, T. Stey, S. Zacchini, J. Chem. Soc., Dalton Trans. 2004, 989-995.

(141) a) D. Leusser, J. Henn, N. Kocher, B. Engels, D. Stalke, J. Am. Chem. Soc. 2004, 126, 1781-1793. b) N. Kocher, J. Henn, B. Gostevskii, D. Kost, I. Kalikhman, B. Engels, D. Stalke, J. Am. Chem. Soc. 2004, 126, 5563-5568. 
(142) C. Cui, H. W. Roesky, M. Noltemeyer, M. F. Lappert, H.-G. Schmidt, H. Hao, Organometallics 1999, 18, 2256-2261.

(143) a) H. Zhu, J. Chai, H. W. Roesky, M. Noltemeyer, H.-G. Schmidt, D. Vidovic, J. Magull, Eur. J. Inorg. Chem. 2003, 3113-3119, and references therein. b) V. Jancik, M. M. Moya Cabrera, H. W. Roesky, R. Herbst-Irmer, D. Neculai, A. M. Neculai, M. Noltemeyer, H.-G. Schmidt, Eur. J. Inorg. Chem. 2004, 3508-3512.

(144) C. Cui, H. W. Roesky, H. Hao, H.-G. Schmidt, M. Noltemeyer, Angew. Chem. 2000, 112, 1885-1887; Angew. Chem., Int. Ed. 2000, 39, 1815-1817.

(145) V. Jancik, Y. Peng, H. W. Roesky, J. Li, D. Neculai, A. M. Neculai, R. Herbst-Irmer, J. Am. Chem. Soc. 2003, 125, 1452-1453.

(146) P. D. Godfrey, C. L. Raston, B. W. Skelton, V.-A. Tolhurst, A. H. White, Chem. Commun. 1997, 2235-2236.

(147) a) J. Müller, R. Schröder, R. Wang, Eur. J. Inorg. Chem. 2000, 153-157. b) R.-C.Yu, C.-H. Hung, J.-H. Huang, H.-Y. Lee, J.-T. Chen, Inorg. Chem. 2002, 41, 6450-6455.

(148) Y. Ying, T. Schultz, M. John, A. Ringe, H. W. Roesky, D. Stalke, J. Magull, Y. Hongqi, Inorg. Chem. 2008, 47, 2585-2592.

(149) J. K. Ruff, M. F. Hawthorne, J. Am. Chem. Soc. 1961, 83, 535-538.

(150) R. L. Stapleton, J. Chai, N. J. Taylor, S. Collins, Organometallics 2006, 25, 25142524 .

(151) M. Waggoner, M. M. Olmstead, P. P. Power, Polyhedron 1990, 9, 257-263.

(152) C. H. Lee, Y. H. La, S. J. Park, J. W. Park, Organometallics 1998, 17, 3648-3655.

(153) S.Singh, S. S. Kumar, V. Chandrasekhar, H.-J. Ahn, M. Biadene, H. W. Roesky, S. N. Hosmane, M. Noltemeyer, H.-G. Schmidt, Angew. Chem. 2004, 116, 5048-5051; Angew. Chem., Int. Ed. 2004, 43, 4940-4943.

(154) S. Singh, V. Jancik, H. W. Roesky, R. Herbst-Irmer, Inorg. Chem. 2006, 45, 949-951. 
(155) L. W. Pineda, V. Jancik, H. W. Roesky, D. Neculai, A. M. Neculai, Angew. Chem. 2004, 116, 1443-1445; Angew. Chem., Int. Ed. 2004, 43, 1419- 1421.

(156) P. M. Gurubasavaraj, H. W. Roesky, P. M. V. Sharma, R. B. Oswald, D. Dolle, A. Pal, Organometallics 2007, 26, 3346-3351.

(157) B. Hübler-Blank, M. Witt, H. W. Roesky, J. Chem. Educ. 1993, 70, 408-409. 


\section{List of publications}

1) Angew. Chem. 2009, 121, 4587-4590; Angewandte Chemie International Edition, 2009, 48, 4517-4520. “Addition of Dimethylaminobismuth to Aldehydes, Ketones, Alkenes, and Alkynes' B. Nekoueishahraki, S. Pillai Sarish, H. W. Roesky, D. Stern, C. Schulzke and D. Stalke.

(2) Inorganic Chemistry, 2008, 47, 5324-5331. "From Unstable to Stable and Highly Active-Heterobimetallic Half-Metallocene Catalysts for Olefin Polymerization and Co-polymerization: Discussion on Structure/Reactivity Relationships" P. M. Gurubasavaraj, H. W. Roesky, B. Nekoueishahraki,S. K. Mandal, R. B. Oswald, A. Pal and R. Herbst-Irmer.

(3) Organometallics 2009, 28, 5733-5738. "Synthesis and Structural Characterization of Heterobimetallic Bismuth Complexes with Main Group and Transition Metals" B. Nekoueishahraki, A. Jana, H. W. Roesky, D. Stern and D. Stalke.

(4) Inorganic Chemistry 2009, 48, 9174-9179. "Synthesis and Structural Characterization of Aluminum Iminophosphonamide Complexes" B. Nekoueishahraki, H. W. Roesky, G. Schwab, D. Stern and D. Stalke.

(5) Organometallics 2009, 28, 3763-3766. " Stable Compounds of Composition LGe $(I I) R\left(R=\mathrm{OH}, \mathrm{PhO}, \mathrm{C}_{6} \mathrm{~F}_{5} \mathrm{O}, \mathrm{PhCO}_{2}\right)$ Prepared by Nucleophilic Addition Reactions ' A. Jana, B. Nekoueishahraki, H. W. Roesky and C. Schulzke.

(6) Inorganic Chemistry (Article) (manuscript under preparation), " Organobismuth(III) and Dibismuthine Complexes Bearing N,N'-Disubstituted 1,8-Diaminonaphthalene Ligand: Synthesis, Structure and Reactivity ", Bijan Nekoueishahraki, H. W. Roesky, Lallan Mishra, Daniel Stern, Dietmar Stalke and Carola Schulzke 


\section{Lebenslauf}

Name

Geboren

Staatsangehörigkeit

Schulbesuch

Studium

Promotion 2006 Jan-present
Bijan Nekoueishahraki

21. September 1974 in Shahrekord, Iran

iranisch

1980-1985

Primary School

$1985-1988$

Secondary School

$1988-1992$

High School

1993- 1997

B.Sc. Esfahan University, Iran

$2002-2005$

M.Sc., Chamran University, Iran

Experimentelle Promotionsarbeit im Institut für

Anorganische Chemie Göttingen unter der Leitung von Prof. Dr. Dr. h.c. mult. H. W. Roesky 